




\title{
Ecología y conservación del pico mediano Dendrocopos medius en ambientes alterados y fragmentados
}

\author{
Memoria presentada por \\ Carlos Ciudad Trilla \\ para optar al grado de Doctor en Biología
}

Codirigida por:

Dr. Francisco José Purroy Iraizoz, Universidad de León, España Dr. Hugo Robles Díez, Universidad de Amberes, Bélgica

Área de Zoología

Departamento de Biodiversidad y Gestión Ambiental

Universidad de León

España

León, 2011 
A Aída, por su paciencia A Leo, al que espero no llenar la cabeza de pájaros 
On a path

Of soft blue

And warm yellow

I wander

All the wrinkles of earth's body

Are flooded with lights

The elements face each other

In a gentle passion of daybreak

The birds sing songs

I've incubated myself

Released to hazy distances

I live awaiting the wonder

That will happen

Later today

At the eleventh hour

(Galsan Tschinag)

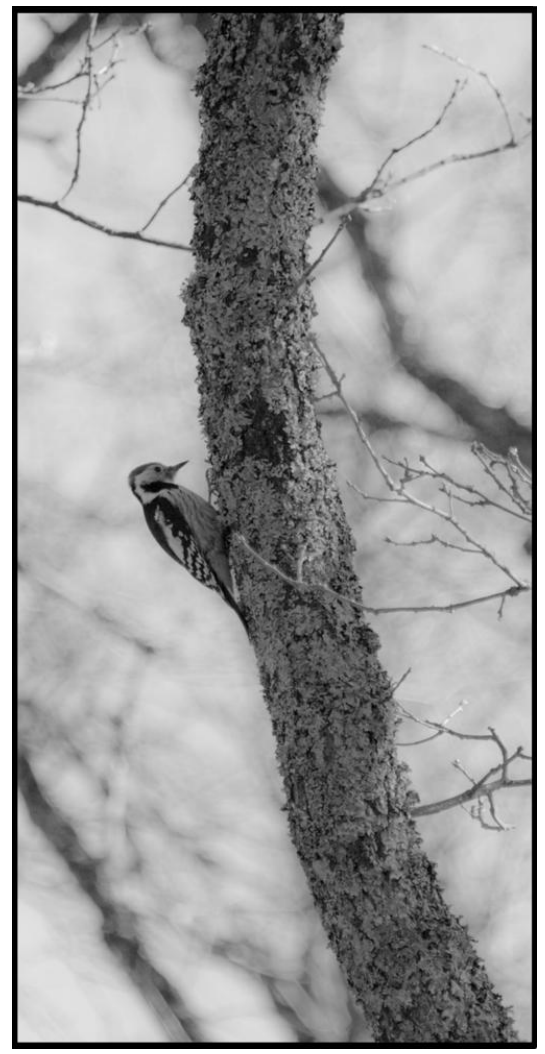




\section{ÍNDICE}

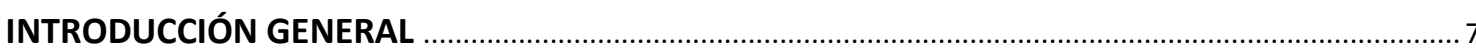

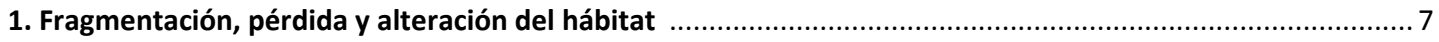

2. Respuesta de las aves forestales a la fragmentación, pérdida y alteración de su hábitat ............................. 8

2.1 Demografía de las aves en ambientes alterados y fragmentados ......................................................... 9

2.2. Procesos de dispersión de las aves en ambientes alterados y fragmentados ........................................ 10

2.3. Selección del hábitat de los juveniles en ambientes alterados durante el periodo post-vuelo ................. 11

2.4. Ocupación, colonización y extinción de los parches en ambientes alterados y fragmentados ................ 12

3. El pico mediano como especie modelo en estudios de fragmentación, pérdida y alteración del hábitat ......12

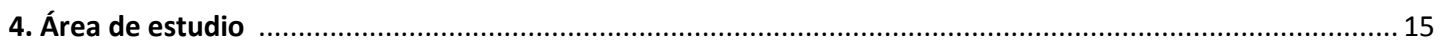

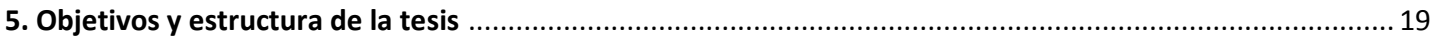

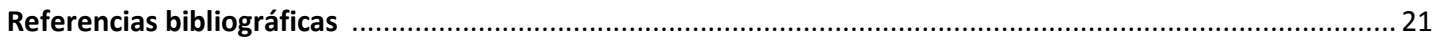

CAPÍTULO I - DEMOGRAFÍA

Demographic responses of middle spotted woodpeckers to habitat fragmentation

CAPÍTULO II - DISPERSIÓN

Influence of habitat quality, population density, patch size and connectivity on multiple dispersal stages in the middle spotted woodpecker

CAPÍTULO III - SELECCIÓN DEL HÁBITAT DE LOS JUVENILES 92

Post-fledging habitat selection of juvenile middle spotted woodpeckers: a multiple-scale approach

CAPÍTULO IV- OCUPACIÓN, COLONIZACIÓN Y EXTINCIÓN DE LOS PARCHES DE HÁBITAT ......112 Testing assumptions of metapopulation models: the influence of habitat quality, population size, patch size and connectivity on occupancy and turnover rates of middle spotted woodpeckers

DISCUSIÓN GENERAL

1. Efectos de la fragmentación, pérdida y alteración del hábitat del pico mediano ...................................... 134

2. Implicaciones en la conservación del pico mediano ............................................................................... 140

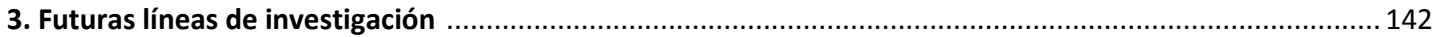

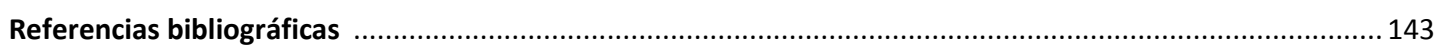

CONCLUSIONES 


\section{INTRODUCCIÓN GENERAL}

\section{Fragmentación, pérdida y alteración del hábitat}

La fragmentación del hábitat es el proceso por el cual una superficie continua de hábitat se divide en varios fragmentos denominados parches de hábitat (Lindenmayer \& Fischer 2006). Los procesos de fragmentación habitualmente implican (a) una pérdida de hábitat y (b) un cambio en la configuración del hábitat restante 0 fragmentación per se, con un incremento del número de parches de hábitat, una reducción del tamaño de los parches y un aumento de la distancia entre ellos (Fahrig 2003, Lindenmayer \& Fischer 2006). Al margen de los procesos de fragmentación y pérdida de hábitat, los parches de hábitat naturales que permanecen en el paisaje pueden estar sometidos a procesos de alteración (Lens et al. 2002). En conjunto, la fragmentación, pérdida y alteración de los hábitat naturales son responsables del declive de la mayor parte de las especies amenazadas del planeta (Baillie et al. 2004, Lindenmayer \& Fischer 2006). En la actualidad son las perturbaciones antrópicas las principales causantes de la fragmentación, pérdida y alteración de los hábitats naturales (Andrén 1994, Forman 1997, Baillie et al. 2004, Groom et al. 2006), con un efecto negativo particularmente importante sobre las poblaciones de especies especialistas de hábitat (Devictor et al. 2008).

La pérdida de hábitat ocasiona una reducción del tamaño de las poblacionales de los organismos que ocupan ese hábitat, lo que puede dar lugar a extinciones locales (Wilcox \& Murphy 1985). Además de una reducción de la capacidad de carga asociada con la disminución del tamaño de los parches (Zanette et al. 2000), los parches más pequeños presentan comparativamente una mayor relación perímetro/superficie, también denominado "efecto de borde" (edge effect; Murcia 1995). Debido al incremento de la cantidad de borde, se modifican las condiciones físico-químicas y se acrecienta la depredación y el parasitismo de cría en los parches pequeños (Fletcher 2005). Por otra parte, el aumento de la distancia entre los parches de hábitat intensifica el aislamiento, especialmente en las especies con baja capacidad de dispersión o con limitaciones comportamentales para atravesar hábitats adversos (Stamps et al. 1987). Al margen de la distancia, la configuración espacial del paisaje y la 
estructura y composición de la matriz (i.e. los diferentes tipos de hábitats que rodean a los fragmentos de hábitat original) también pueden influir sobre el grado de aislamiento (Gascon et al. 1999, Villard et al. 1999, Fahrig 2001, Lindenmayer \& Fisher 2006). La reducción de la conectividad (i.e. el aumento del aislamiento) dificulta los desplazamientos de los individuos entre los parches de hábitat, por lo que puede limitar el flujo génico, reduciéndose la variabilidad genética y llegando a producirse en algunos casos fenómenos de depresión endogámica que lleven a la extinción de las poblaciones locales (Saccheri et al. 1998, Hedrick \& Kalinowski 2000, Cooper \& Walters 2002).

La alteración de los hábitat naturales puede incrementar los niveles de estrés (ej. un incremento del riesgo de depredación, una reducción de la disponibilidad de alimento o de lugares de cría) sobre los organismos, de tal manera que una vez superado cierto umbral de estrés su persistencia se ve seriamente comprometida debido en parte a una reducción en el éxito reproductivo o en la supervivencia (Lens et al. 2002, Krams et al. 2010). Habitualmente la degradación del hábitat remanente está asociada a procesos de fragmentación y pérdida del hábitat (Tabarelli \& Gascon 2005). No obstante, también en hábitats continuos la alteración antropogénica puede ocasionar una degradación del hábitat que implica un deterioro de su calidad intrínseca (Mortelliti et al. 2010).

\section{Respuesta de las aves forestales a la fragmentación, pérdida y alteración de su}

\section{hábitat}

La fragmentación, pérdida y alteración de los hábitat naturales han llevado al declive de numerosas poblaciones de aves forestales (Lampila et al. 2005). Los efectos negativos de estos procesos espaciales han sido documentados en muchos estudios de aves migratorias neotropicales (ej. Donovan et al. 1995, Robinson et al. 1995, Porneluzi \& Faaborg 1999, Bayne \& Hobson 2001, Doherty \& Grubb 2002), pero los efectos de la fragmentación, pérdida y alteración de los hábitat sobre las poblaciones de aves del Paleártico son poco conocidos. Además, a pesar de que se han descrito los patrones del declive poblacional en varias especies, se conoce muy poco sobre los mecanismos ecológicos subyacentes al declive de las poblaciones de aves forestales (Lampila et al. 
2005). A continuación se describen algunas de las afecciones que las modificaciones en los hábitats naturales pueden provocar sobre la distribución, la demografía o la dispersión de las aves.

\subsection{Demografía de las aves en ambientes alterados y fragmentados}

Las poblaciones en hábitat fragmentados y alterados persisten en el tiempo cuando la reproducción y la supervivencia juvenil compensan la mortalidad de los adultos, o cuando la inmigración equilibra el crecimiento negativo de la población (Watkinson \& Sutherland 1995). En este sentido, el conocimiento de las respuestas demográficas de las aves frente a escenarios de fragmentación, pérdida y alteración de su hábitat es esencial a la hora de identificar los mecanismos que pueden llevan a los declives poblacionales.

La reducción del tamaño y de la calidad de los parches de hábitat pueden afectar la supervivencia de las aves, al disminuir los recursos disponibles (Luck 2003) y aumentar la depredación y la competencia con especies generalistas provenientes de los hábitats circundantes (Murcia 1995). La reducción de la conectividad entre los parches también puede tener un efecto negativo indirecto sobre la supervivencia, debido al riesgo que supone para algunas especies atravesar hábitats adversos (Bélisle \& Desrochers 2002, Yoder et al. 2004). Este posible incremento de la mortalidad suele darse especialmente en los juveniles, como consecuencia de su inexperiencia en la búsqueda de alimento (Wheelwright \& Templeton 2003), sus menores habilidades locomotoras (Yoda et al. 2004) y de que son los que realizan los mayores desplazamientos (Greenwood \& Harvey 1982).

El éxito reproductor de las aves puede disminuir en ambientes fragmentados y alterados debido al incremento de la depredación de los nidos y del parasitismo de cría en los parches de menor tamaño (i.e. efecto de borde), y por la escasez de lugares de cría y de recursos para la alimentación de los pollos en los fragmentos de hábitat pequeños y degradados (Holmes et al. 1996, Burke \& Nol 1998, Luck 2003). Además, la fragmentación, pérdida y alteración del hábitat pueden afectar negativamente a la fecundidad de las aves reduciendo el éxito de emparejamiento de los machos. Esto podría suceder en caso de que las hembras prefieran no emparejarse en parches 
pequeños y degradados con baja disponibilidad de recursos para la reproducción y fuerte riesgo de depredación (Githiru \& Lens 2006), o bien si las hembras no son capaces de alcanzar los parches más aislados a través de movimientos dispersivos (Dale 2001, Cooper \& Walters 2002).

\subsection{Procesos de dispersión de las aves en ambientes alterados y fragmentados}

La dispersión, definida como el movimiento de un organismo desde su lugar de origen hasta una nueva área en la que asentarse (Krebs 2001), es un evento esencial en la dinámica poblacional de los organismos que habitan en ambientes fragmentados y alterados (Hanski \& Gilpin 1997). El movimiento de individuos entre parches de hábitat mantiene la variabilidad genética, reduce la endogamia y puede rescatar poblaciones locales de la extinción gracias a la llegada de inmigrantes (rescue effect; Brown \& Kodric-Brown 1977, Clobert et al. 2001). Sin embargo, a pesar de su importancia, se conoce muy poco sobre los movimientos dispersivos de los organismos en paisajes fragmentados y alterados (Van Dyck \& Baguette 2005).

El proceso de dispersión es en parte dependiente de las condiciones ambientales; es decir, los individuos utilizan señales externas para ajustar sus tácticas dispersivas (condition-dependent dispersal; Ims \& Hjermann 2001). No es de extrañar, por tanto, que la fragmentación, pérdida y alteración del hábitat puedan tener efectos considerables sobre la dispersión de los organismos, con importantes consecuencias en la dinámica de sus poblaciones. Por ejemplo, la pérdida de hábitat puede favorecer la filopatría (i.e. tendencia a permanecer cerca del lugar de nacimiento) debido al aumento del coste de la emigración fuera de los parches de hábitat óptimo (Travis \& Dytham 1999), mientras que el efecto del incremento del aislamiento entre los parches de hábitat derivado de la fragmentación varía dependiendo del riesgo de extinción dentro de los parches y de la tasa de mortalidad durante la dispersión (Heino \& Hanski 2001). Además, la degradación del hábitat puede estimular la dispersión para escapar de condiciones adversas, tales como la escasez de recursos alimenticios (Dickinson \& McGowan 2005, Baglione et al. 2006). Por otra parte, las aves que se dispersan entre parches de hábitat pueden evitar asentarse en aquéllos parches más pequeños y degradados, que serían evaluados como parches de baja calidad. 
2.3. Selección del hábitat de los juveniles en ambientes alterados durante el periodo post-vuelo

La conservación de las especies requiere de la protección de los recursos críticos durante todas las etapas vitales (Anders et al. 1998, Vega Rivera et al. 1998). Sin embargo, la mayoría de los planes de conservación de las poblaciones de aves están basados esencialmente en la protección de los hábitats de cría (Penteriani \& Delgado 2009). Estas estrategias podrían no ser efectivas en caso de que los juveniles utilicen hábitats diferentes al hábitat de cría durante el "periodo post-vuelo" (postfledging period) (Anders et al. 1998, Vega Rivera et al. 1998, White et al. 2005). Este periodo comprende desde el momento en que los volantones abandonan el nido, hasta que inician la migración otoñal (en especies migratorias) o se establecen en áreas de campeo invernales o permanentes (en especies no migratorias). Al principio los juveniles siguen siendo alimentados y protegidos por los padres generalmente dentro del área natal (etapa de dependencia); después los padres dejan de atenderles de forma regular y normalmente se dispersan fuera del área natal (etapa de independencia).

La importancia de la comprensión de las decisiones de uso del hábitat por los juveniles en el periodo post-vuelo radica además en que en este momento las aves están sujetas a un alto riesgo de mortalidad, debido a su inexperiencia (Wheelwright \& Templeton 2003, Yoda et al. 2004) y a los elevados índices de depredación a los que están expuestos (Naef-Daenzer et al. 2001, Robles et al. 2007b). Además, durante este periodo los juveniles realizan los mayores movimientos de dispersión en aves (Greenwood \& Harvey 1982), vitales para la persistencia de las poblaciones (ver apartado anterior). Con frecuencia, los juveniles abandonan el área natal en busca de nuevas zonas donde alimentarse, protegerse de los depredadores, evitar la competencia y tener futuras oportunidades de cría (Vega Rivera et al. 1998, Lambin et al. 2001, White et al. 2005). Por lo tanto, para poder establecer medidas adecuadas para la conservación de las poblaciones de aves es primordial ampliar el conocimiento del uso del hábitat de los juveniles y los efectos que las perturbaciones antropogénicas pueden tener sobre el mismo. 
2.4. Ocupación, colonización y extinción de los parches en ambientes alterados y fragmentados

Aunque varios estudios previos han mostrado que la fragmentación, pérdida y alteración del hábitat pueden influir sobre las tasas de ocupación, colonización y extinción de los parches de hábitat, existe una fuerte controversia sobre cómo estos procesos espaciales afectan a la dinámica de colonización-extinción. Por ejemplo, la mayoría de los modelos sobre dinámica metapoblacional asumen que se produce un incremento de las extinciones al reducirse el tamaño de los parches, usado como un sustituto (surrogate) del tamaño poblacional, y un descenso de las colonizaciones al disminuir su conectividad (Kindvall \& Ahlén 1992, Thomas \& Harrison 1992, Thomas et al. 1992, Hanski 1998, Moilanen et al. 1998). Sin embargo, algunos autores han encontrado que el tamaño de los parches no es un buen sustituto del tamaño poblacional para explicar la tasa de extinción, mientras que la conectividad no es un buen predictor de la tasa de colonización en algunos sistemas (Pellet et al. 2007, Franzén \& Nilsson 2010). Además, algunos estudios sugieren que la calidad intrínseca de los parches de hábitat (inversa a la alteración del hábitat) es el predictor "olvidado" en los modelos de la dinámica metapoblacional, ya que los parches más alterados están sujetos a mayores tasas de extinción y bajas tasas de colonización (Fleishman et al. 2002, Franken \& Hik 2004, Franzén \& Nilsson 2010).

\section{El pico mediano como especie modelo en estudios de fragmentación, pérdida y alteración del hábitat}

Para analizar los efectos de la fragmentación, pérdida y alteración de los hábitats lo ideal sería poder estudiar todos los organismos que pudieran verse afectados. Sin embargo, la limitación de recursos disponibles y las dificultades técnicas existentes en algunos casos para llevar a cabo estos estudios, hacen que los investigadores se vean obligados a estudiar una especie o un grupo de especies sensibles a estos cambios ambientales y cuyos efectos sean representativos para otros organismos (indicator species; Simberloff 1998, Hilty \& Merenlender 2000, Mikusinski et al. 2001). A continuación se describen varios aspectos de la biología y ecología del pico mediano (Dendrocopos medius) con el fin de mostrar su idoneidad como especie indicadora. 
El pico mediano es un pájaro carpintero de tamaño medio (aproximadamente 21 cm y 55 g; Fig. 1a) que se distribuye por el Paleártico occidental (Pasinelli 2003; Fig. 1c). En España, se distribuye de forma irregular por los bosques caducifolios del norte de la Península Ibérica (Onrubia et al. 2003; Fig. 1d). A nivel mundial la especie está incluida en la categoría Preocupación Menor (BirdLife International 2010), mientras que en España está catalogada como Casi Amenazada, aunque la escasez de datos sobre sus tendencias poblacionales y cambios en la distribución hacen difícil su catalogación (Onrubia et al. 2004).

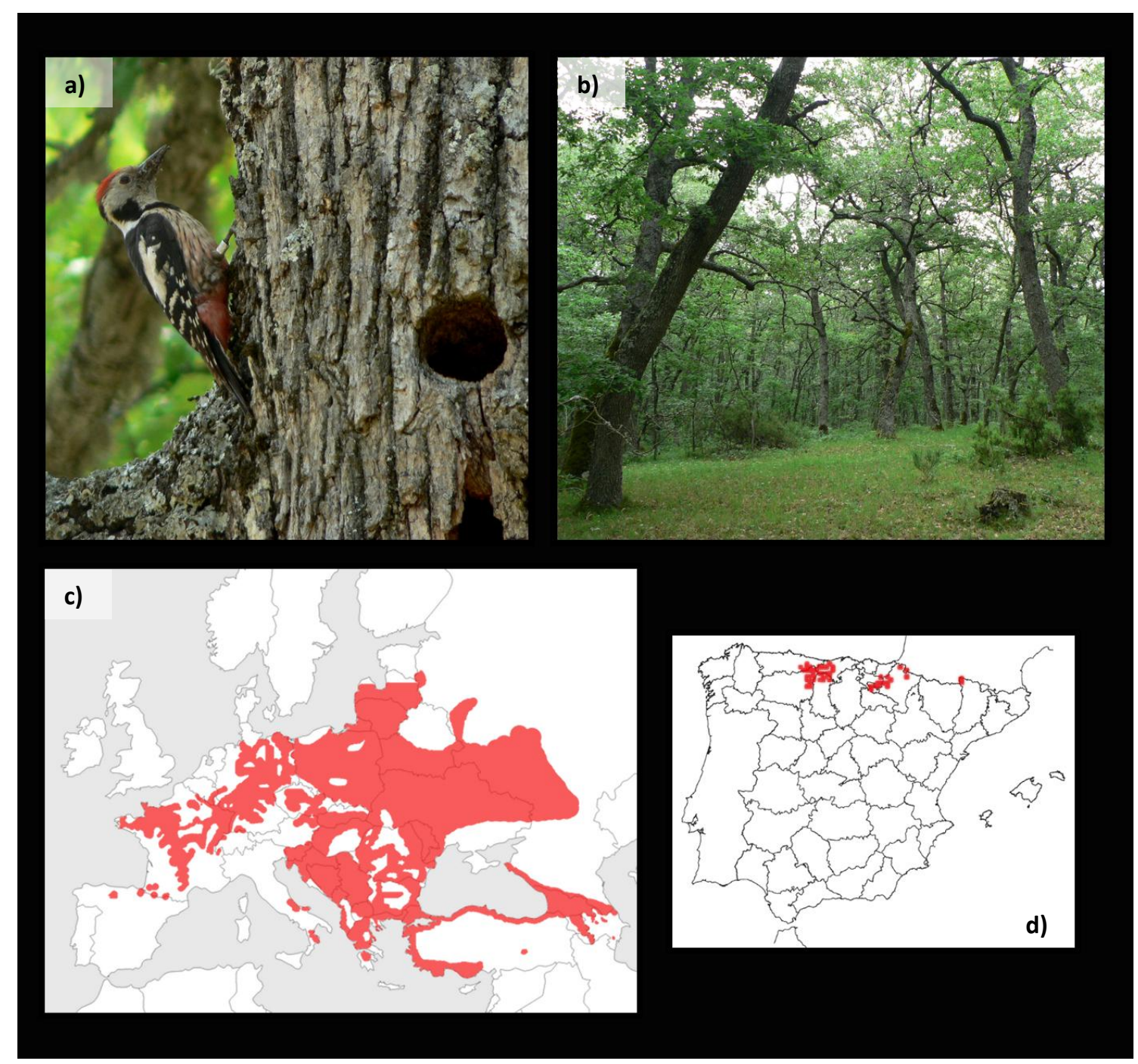

Fig. 1. Hembra de pico mediano en las inmediaciones de la cavidad de cría (a), hábitat característico del pico mediano (b), distribución mundial (modificado de Pasinelli 2003) (c) y nacional (modificado de Onrubia et al. 2003) (d) de la especie. 
Se trata de un especialista de bosques caducifolios maduros con árboles de corteza rugosa (Pasinelli 2003; Fig. 1b). Probablemente la preferencia por este tipo de hábitat se basa en la elevada riqueza de artrópodos (su principal fuente de alimento) que albergan las fisuras y la superficie de la corteza de estos árboles (Petterson 1983, Pasinelli \& Hegelbach 1997, Robles et al. 2007a). Para alimentarse seleccionan los árboles de gran diámetro, especialmente robles (Pasinelli \& Hegelbach 1997, Pasinelli 2000, Robles et al. 2007a). La madera muerta no parece ser tan relevante para la búsqueda de alimento como en otros pájaros carpinteros, aunque durante el periodo invernal y en bosques dominados por especies de corteza más lisa (ej. hayedos) su utilización se incrementa notablemente (Pasinelli 2003). El sistema social se caracteriza por la monogamia (Michalek \& Winkler 2001) y la territorialidad (Pasinelli et al. 2001). Generalmente cada año construyen una nueva cavidad de cría, en árboles decadentes (i.e. con el tronco parcialmente descortezado y/o hongos afiloforales) y con presencia previa de huecos (naturales o excavados por pájaros carpinteros) (Pasinelli 2003, Kosiński \& Winiecki 2004, Pasinelli 2007, Robles et al. 2007a). Realizan una única puesta anual (Pasinelli 2003). El macho y la hembra comparten las labores de cría (Michalek \& Winkler 2001). Se considera una especie no migratoria, cuyos movimientos de dispersión parece que son relativamente limitados, aunque la información sobre su dispersión es muy escasa (Kossenko 2003, Pasinelli 2003).

En las últimas décadas se ha demostrado que el pico mediano es una especie sensible a los cambios antropogénicos de su hábitat. En cuanto a las alteraciones del hábitat, la reducción de la disponibilidad de árboles importantes para la alimentación (i.e. de gran diámetro) y para anidar (i.e. decadentes y con huecos) limita la distribución de la especie (Pasinelli 2000, Robles et al. 2007a), por lo que los bosques con extracción selectiva de estos árboles y los bosques jóvenes no son ocupados por parejas reproductoras (Pasinelli 2003, Robles et al. 2007a). Sin embargo, pese a ser un especialista, se ha visto que tiene una cierta plasticidad para adaptarse a hábitats diferentes (como los hayedos en Europa central; Pasinelli 2003) y con cierto grado de alteración antropogénica (robledales adehesados de la Cordillera Cantábrica; Robles et al. 2007a). La fragmentación del hábitat disminuye las probabilidades de ocupación y la densidad de parejas reproductoras (Kossenko \& Kaygorodova 2001), lo que puede 
llevar a la extinción de sus poblaciones (Pettersson 1985). A escala de paisaje, no se han encontrado diferencias significativas en el éxito reproductivo entre áreas de hábitat continuo y áreas más fragmentadas (Robles 2004, Kossenko \& Kaygorodova 2007), pero no se han realizado estudios sobre los efectos de las variables directamente relacionadas con la fragmentación (ej. tamaño y aislamiento de los parches) en la reproducción. La supervivencia anual de los adultos es relativamente elevada $(0.786 \pm 0.074)$, lo que contrasta con la supervivencia anual de los juveniles $(0.255 \pm 0.044)$, cuya mortalidad es especialmente fuerte en las tres primeras semanas después de abandonar el nido (tasa de supervivencia: $0.359 \pm 0.077$ ) (Robles et al. 2007b). La supervivencia de adultos y juveniles no está fuertemente afectada por el tamaño y aislamiento de los parches asociados con la fragmentación del hábitat (Robles et al. 2007b).

Como creador primario de cavidades, proporciona huecos en los árboles a otros organismos que dependen de ellos para criar o protegerse (Martin et al. 2004), por lo que se considera una especie clave (keystone species; Power et al. 1996) dentro de los ecosistemas forestales. Además, es una especie indicadora de la riqueza y abundancia de otras aves forestales (Roberge \& Angelstam 2006). Estas características como especie clave e indicadora, unido a su potencial sensibilidad frente a las perturbaciones antropogénicas de su hábitat, hacen que el pico mediano sea una especie idónea para el análisis de los efectos de la fragmentación, pérdida y alteración de los robledales viejos (i.e. su hábitat en la Cordillera Cantábrica), con implicaciones potenciales en la conservación de otras aves forestales europeas.

\section{4. Área de estudio}

Esta tesis se ha desarrollado principalmente en la vertiente sur de la Cordillera Cantábrica, entre el noreste de la provincia de León y el noroeste de la provincia de Palencia (centrada geográficamente a $42^{\circ} 41^{\prime} \mathrm{N}, 5^{\circ} 1^{\prime} \mathrm{W}$; Fig. 2). El área de estudio representa el límite suroccidental de distribución mundial del pico mediano (Pasinelli 2003, Robles et al. 2007a; Fig. 1c). Se encuentra localizada en la zona de transición entre las regiones bioclimáticas Mediterránea y Eurosiberiana, tiene una extensión aproximada de $750 \mathrm{~km}^{2}$ (la superficie varía en función del estudio) y altitudes entre 
900 y 1250 m s.n.m. Se caracteriza por ser una zona agroforestal, donde los robledales (principalmente de Quercus pirenaica, pero también $Q$. faginea, Q. petraea y $Q$. paucirradiata; ver Penas 1995, Penas et al. 1997) son los bosques predominantes y se distribuyen por el paisaje en forma de parches con distinto grado de madurez (Tabla 1, Fig. 2). Otros tipos de hábitats forestales presentes en la zona son plantaciones de pinos (principalmente de Pinus sylvestris y P. pinaster), bosques de ribera (Populus sp., Salix sp.), encinares (Q. rotundifolia), hayedos (Fagus sylvatica) y sabinares (Juniperus thurifera) (Tabla 1, Fig. 2). Los hábitats no forestales están compuestos por cultivos de cereal de secano, pastizales, matorrales, roquedos, explotaciones mineras a cielo abierto, infraestructuras y zonas urbanas (Tabla 1, Fig. 2). Una parte de la superficie está declarada Lugar de Importancia Comunitaria (LIC “Rebollares del Cea").

Tabla 1. Porcentaje de superficie ocupada por cada tipo de hábitat (respecto de la superficie total) en el área de estudio de la Cordillera Cantábrica.

\section{Tipo de hábitat}

1- Cubierta forestal

a) Robledales

- Robledales viejos

- Robledales maduros*

- Dehesas de roble*

- Robledales jóvenes

b) Plantaciones de pinos

c) Bosques de ribera

d) Encinares

e) Hayedos

f) Sabinares

2- Cubierta no forestal

\section{Superficie (\%)}

56,10

33,57

4,45

2,84

1,61

29,12

19,76

2,00

0,60

0,15

0,02

\footnotetext{
* Hábitat potencial de cría del pico mediano
} 


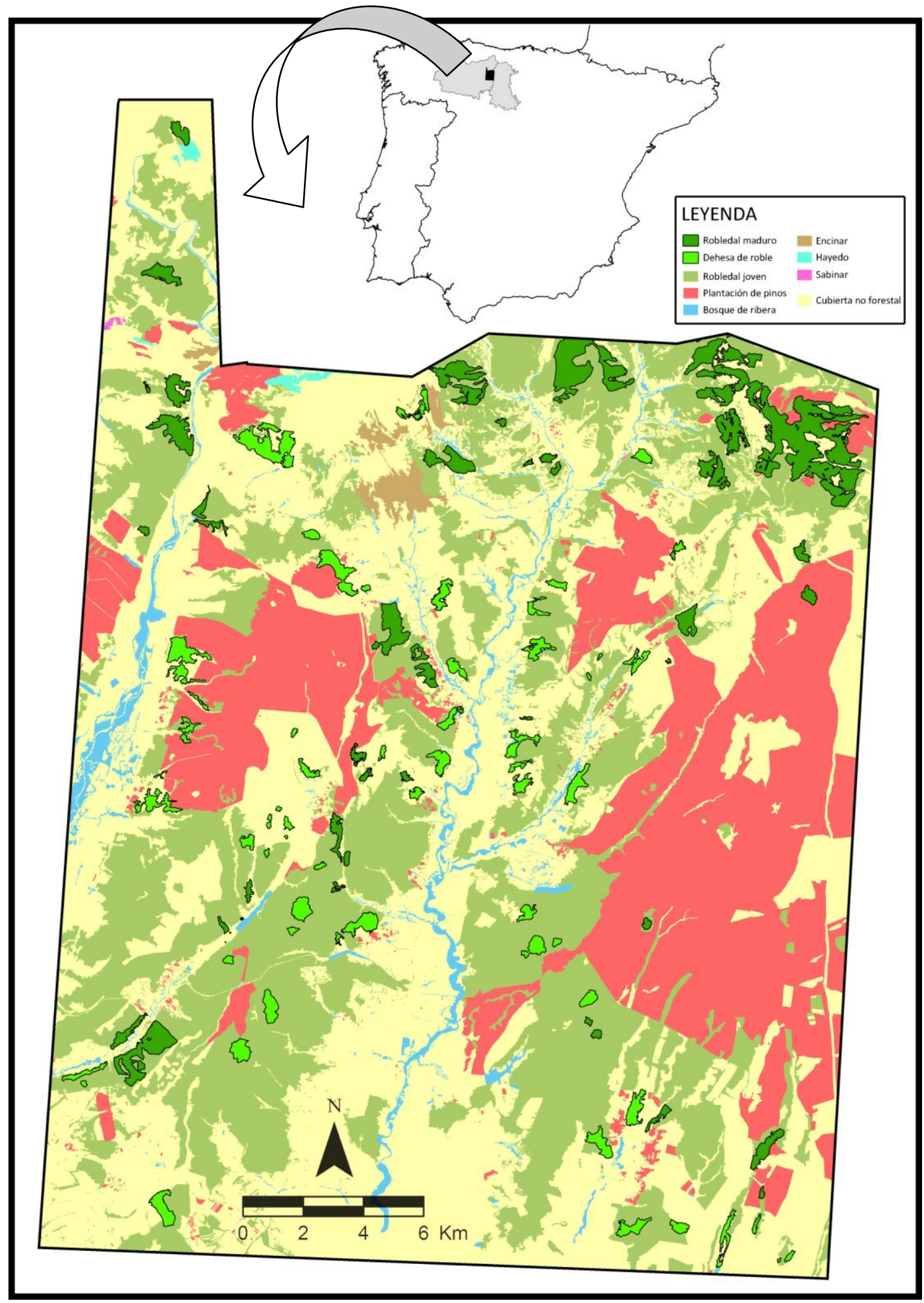

Fig. 2. Situación del área de estudio y mapa de hábitats elaborado en ArcGiS 9.2 a escala 1:2000 a partir de ortofotografías digitales de alta resolución $(0,25 \mathrm{~m})$. 
En esta zona, el pico mediano utiliza como hábitat de cría los parches de robledal maduro y las dehesas de roble (Robles et al. 2007a), esencialmente en los melojares supramediterráneos. Estos ecosistemas presentan una extraordinaria riqueza de especies de aves (Carrascal \& Lobo 2003), a pesar de ser los bosques con menor superficie protegida de España (Maldonado et al. 2001). A lo largo de la historia, han sufrido una intensa intervención humana. Gran parte de estos melojares se deforestaron para ser sustituidos por cultivos y zonas de pasto o para extraer madera (Blanco et al. 1997). Además, buena parte del área potencial de melojar ha sido ocupada por plantaciones de pinos (Luis-Calabuig et al. 2000, Onrubia et al. 2004, Loidi 2005). También las prácticas forestales tradicionales (el carboneo, la extracción de leña o el pastoreo) han configurado la distribución y estructura de estos bosques (Tárrega et al. 2006). Algunas de estas prácticas tradicionales han contribuido al mantenimiento hasta nuestros días de las dehesas de roble melojo, asociadas a sistemas de ganadería en extensivo, fundamentalmente de ovejas y cabras. En estas dehesas, mediante cortas selectivas se ha favorecido el desarrollo de árboles de gran porte, por lo que han seguido siendo un hábitat adecuado para el pico mediano (Robles et al. 2007a). Durante el siglo XX, el abandono de las tierras de cultivo y la disminución de la corta de robles asociados a la despoblación de las áreas rurales han contribuido a una nueva expansión del melojar (Luis-Calabuig et al. 2000). Sin embargo, esta recolonización forestal está provocada por la regeneración de robles melojos desde la cepa, que sin el mantenimiento adecuado (cortas selectivas para evitar competencia, pastoreo, etc.), no podrán alcanzar un diámetro adecuado para el pico mediano. Como resultado de todos estos procesos, en nuestros días los parches de robledal viejo (robledal maduro y dehesas), que constituyen el hábitat potencial de cría del pico mediano, se distribuyen en fragmentos ( $\sim \%$ del área de estudio) sobre una matriz compuesta mayoritariamente de robledal joven, plantaciones de pinos y hábitats abiertos no forestales (Tabla 1, Fig. 2). 


\section{Objetivos y estructura de la tesis}

El objetivo principal de esta tesis es profundizar en el conocimiento de los efectos que tienen los procesos de fragmentación, pérdida y alteración del hábitat sobre los organismos forestales. Para ello, hemos utilizado como especie modelo al pico mediano y nos hemos basado en los conocimientos sobre su ecología descritos en una tesis anterior (Robles 2004) y en algunas publicaciones derivadas de ella (Robles \& Olea 2003, Robles et al. 2007a, 2007b).

Esta tesis está dividida en cuatro capítulos que siguen la estructura típica de un artículo científico. Los capítulos están redactados en inglés y reproducen el texto de manuscritos publicados en revistas científicas internacionales (Capítulos I y III) o en fase de preparación (Capítulos II y IV), con algunas ligeras modificaciones. Los objetivos específicos de cada uno de ellos se describen en los siguientes subapartados.

\section{Capítulo I - Demografía}

DEMOGRAPHIC RESPONSES OF MIDDLE SPOTTED WOODPECKERS TO HABITAT FRAGMENTATION [Respuestas demográficas del pico mediano a la fragmentación del hábitat]

En este capítulo se analiza el efecto de la fragmentación, pérdida y alteración del hábitat sobre varios parámetros demográficos del pico mediano. Con este fin, se examinan las relaciones entre la calidad del hábitat (inversa de la alteración del hábitat, medida a partir de la densidad de árboles importantes para la alimentación y como sitios de cría), el tamaño y el aislamiento de los parches de hábitat con parámetros reproductivos y el éxito de emparejamiento del pico mediano en la vertiente sur de la Cordillera Cantábrica.

\section{Capítulo II - Dispersión}

INFLUENCE OF HABITAT QUALITY, POPULATION DENSITY, PATCH SIZE AND CONNECTIVITY ON MULTIPLE DISPERSAL STAGES IN THE MIDDLE SPOTTED WOODPECKER 
[Influencia de la calidad del hábitat, la densidad de población, el tamaño y la conectividad de los parches en múltiples etapas de dispersión en el pico mediano]

En este capítulo evaluamos la dispersión de juveniles y adultos de pico mediano en el área de estudio de la Cordillera Cantábrica y en otra área de características similares en Rusia (bosque de Nerussa-Desna). Analizamos los efectos de la pérdida y la fragmentación del hábitat (medidas en función del tamaño y conectividad del parche, incluyendo en esta última las características de la matriz de hábitats circundantes), la degradación del hábitat (medida en relación a la densidad de robles de gran diámetro), la densidad de la población y el sexo sobre múltiples etapas de la dispersión de las aves. En el caso de los juveniles, se examina la emigración desde el parche natal (abandono del parche natal), la distancia de dispersión y la inmigración (asentamiento en parches diferentes al parche natal) en la Cordillera Cantábrica; mientras que en la dispersión de los adultos se analiza la emigración territorial (abandono del territorio de cría) y la distancia de dispersión considerando las dos áreas de estudio.

\section{Capítulo III - Selección del hábitat de los juveniles}

POST-FLEDGING HABITAT SELECTION OF JUVENILE MIDDLE SPOTTED WOODPECKERS: A MULTIPLE-SCALE APPROACH

[Selección de hábitat de juveniles de pico mediano durante el periodo post-vuelo: un enfoque a múltiples escalas]

En este capítulo investigamos las decisiones del uso del hábitat por juveniles de pico mediano radio-marcados durante el periodo post-vuelo. La selección del hábitat se examinó a diferentes escalas espaciales jerárquicamente anidadas: escala de paisaje (selección del área de campeo dentro del paisaje), escala de área de campeo (selección del tipo de bosque dentro del área de campeo) y escala de árbol de forrajeo dentro de los bosques usados por los juveniles. Además, en base a los árboles seleccionados por los juveniles para buscar alimento, comparamos la estructura de la vegetación entre las áreas de campeo y las áreas adyacentes no usadas. 


\section{Capítulo IV - Ocupación, colonización y extinción de los parches de hábitat}

TESTING ASSUMPTIONS OF METAPOPULATION MODELS: THE INFLUENCE OF HABITAT QUALITY, POPULATION SIZE, PATCH SIZE AND CONNECTIVITY ON OCCUPANCY AND TURNOVER RATES OF MIDDLE SPOTTED WOODPECKERS

[Evaluando las asunciones de los modelos metapoblacionales: la influencia de la calidad del hábitat, el tamaño poblacional, el tamaño del parche y la conectividad sobre la ocupación y las tasas de renovación de los picos medianos]

En este último capítulo analizamos la influencia del tamaño y la conectividad de los parches, la calidad del hábitat (medida en función de la densidad de árboles importantes para la alimentación y la reproducción) y el tamaño poblacional (número de territorios) en la ocupación, la colonización y la extinción de los parches de hábitat utilizados por el pico mediano.

Finalmente, se incluye un apartado de Discusión General donde se discuten los resultados más relevantes, sus implicaciones para la conservación y las futuras líneas de investigación derivadas de este trabajo. Además, en otro apartado se enumeran las principales Conclusiones alcanzadas durante esta tesis y se incluye un Anexo Fotográfico para documentar con imágenes algunas de las observaciones a las que se hace referencia en el manuscrito.

\section{Referencias bibliográficas}

Anders, A. D., FAABORg, J. \& Thompson III, F. R. 1998. Postfledging dispersal, habitat use, and home-range size of juvenile wood thrushes. The Auk 115: 349-358.

ANDRÉN, H. 1994. Effects of habitat fragmentation on birds and mammals in landscapes with different proportions of suitable habitat: a review. Oikos 71: 355-366.

Baglione, V., Canestrari, D., Marcos, J. M. \& Ekman, J. 2006. Experimentally increased food resources in the natal territory promotes offspring philopatry and helping in cooperatively breeding carrion crows. Proceedings of the Royal Society of London $B$ 273: 1529-1535. 
Baillie, J. E. M., Hilton-TayloR, C. \& Stuart, S. N. 2004. IUCN red list of threatened species. Gland, Switzerland: IUCN.

BAKER, R. R. 1993. The function of post-fledging exploration: a pilot study of three species of passerines ringed in Britain. Ornis Scandinavica 24: 71-79.

BAYNE, E. M. \& HOBSON K. A. 2001. Effects of habitat fragmentation on pairing success of ovenbirds: importance of male age and floater behavior. The Auk 118: 380-388.

BélisLe, M. \& DesRochers, A. 2002. Gap-crossing decisions by forest birds: an empirical basis for parameterizing spatially-explicit, individual-based models. Landscape Ecology 17: 219-231.

BirdLife InTERnational. 2010. Dendrocopos medius. En: IUCN Red List of Threatened Species. Version 2010.4. <www.iucnredlist.org>. Downloaded on 10 January 2011.

Blanco, E., Casado, M. A., Costa, M., Escribano, R., Génova, M., Gómez, A., Gómez, F., Moreno, J. C., Morla, C., Regato, P. \& Sáinz, H. 1997. Los Bosques Ibéricos. Una interpretación geobotánica. Planeta, Barcelona.

BroWN, J. H. \& KODRIC-Brown, A. 1977. Turnover rates in insular biogeography: effect of immigration on extinction. Ecology 58: 445-449.

BURKE, D. M. \& NOL, E. 1998. Influence of food abundance, nest-site habitat, and forest fragmentation on breeding ovenbirds. The Auk 115: 96-104.

CARRASCAL, L. M. \& LoBO, J. M. 2003. Respuestas a viejas preguntas con nuevos datos: estudio de los patrones de distribución de la avifauna española y consecuencias para su conservación. En: Martí, R. \& Del Moral, J. C. (Eds.), Atlas de las aves reproductoras de España. Dirección General de Conservación de la NaturalezaSociedad Española de Ornitología, Madrid, pp. 651-668.

Clobert, J., Danchin, E., Dhondt, A. A. \& Nichols, J. D. 2001. Dispersal. Oxford University Press, New York.

COOPER, C. B. \& WALters, J. R. 2002. Experimental evidence of disrupted dispersal causing decline of an Australian passerine in fragmented habitat. Conservation Biology 16: 471-478. 
DALE, S. 2001. Female-biased dispersal, low female recruitment, unpaired males, and the extinction of small and isolated bird populations. Oikos 92: 344-356.

Devictor, V., Julliard, R. \& Jiguet, F. 2008. Distribution of specialist and generalist species along spatial gradients of habitat disturbance and fragmentation. Oikos 117: 507-514.

DICKINSON, J. L. \& MCGOWAN, A. 2005. Winter resource wealth drives delayed dispersal and family-group living in western bluebirds. Proceedings of the Royal Society of London B 272: 2423-2428.

Doherty, P. F. \& GRUBB, T. C. 2002. Survivorship of permanent-resident birds in a fragmented forested landscape. Ecology 83: 844-857.

Donovan, T. M., Lamberson, R. H., Kimber, A., Thompson III, F. R. \& FaAborg J. 1995. Modelling the effects of habitat fragmentation on source and sink demography of neotropical migrant birds. Conservation Biology 9: 1396-1407.

FAHRIG, L. 2001. How much habitat is enough? Biological Conservation 100: 65-74.

FAHRIG, L. 2003. Effects of habitat fragmentation on biodiversity. Annual Review of Ecology, Evolution and Systematics 34: 487-515.

Fleishman, E., Ray, C., Suögren-Gulve, P., Boggs, C. L. \& Murphy, D. D. 2002. Assessing the roles of patch quality, area, and isolation in predicting metapopulation dynamics. Conservation Biology 16: 706-716.

FLETCHER JR., R. J. 2005. Multiple edge effects and their implications in fragmented landscapes. Journal of Animal Ecology 74: 342-352.

FORMAN, R. T. T. 1997. Land mosaics: the ecology of landscapes and regions. Cambridge University Press, Cambridge.

Franken, R. J. \& HIK, D. S. 2004. Influence of habitat quality, patch size and connectivity on colonization and extinction dynamics of collared pikas Ochotona collaris. Journal of Animal Ecology 73: 889-896.

FranzÉN, M. \& NiLSSON, S. G. 2010. Both population size and patch quality affect local extinctions and colonizations. Proceedings of the Royal Society of London B 277: 7985. 
Gascon, C., Lovejoy, T. E., BierregaArd JR., R. O., Malcolm, J. R., Stouffer, P. C., Vasconcelos, H. L., Laurance, W. F., Zimmerman, B., Tocher, M. \& Borges, S. 1999. Matrix habitat and species richness in tropical forest remnants. Biological Conservation 91: 223-229.

GITHIRU, M. \& LENS, L. 2006. Annual survival and turnover rates of an Afrotropical robin in a fragmented forest. Biodiversity and Conservation 15: 3315-3327.

Greenwood, P. J. \& Harvey, P. H. 1982. The natal and breeding dispersal of birds. Annual Review of Ecology and Systematics 13: 1-21.

Groom, M. J., Meffe, G. K. \& Carroll, C. R. 2006. Principles of Conservation Biology, 3rd edition. Sinauer, Sunderland, Massachusetts.

HANSKI, I. 1998. Metapopulation dynamics. Nature 396: 41-49.

HANSKI, I. \& GILPIN, M. E. 1997. Metapopulation biology: ecology, genetics and evolution. Academic Press, San Diego.

HedRICK, P. W. \& KALINOWSKI, S. T. 2000. Inbreeding depression in conservation biology. Annual Review of Ecology and Systematics 31: 139-162.

HeINO, M. \& HANSKI, I. 2001. Evolution of migration rate in a spatially realistic metapopulation model. American Naturalist 157: 495-511.

Hilty, J. \& Merenlender, A. M. 2000. Faunal indicator taxa selection for monitoring ecosystem health. Biological Conservation 92: 185-197.

Holmes, R. T., MARRA, P. P. \& SherRY, T. W. 1996. Habitat-specific demography of breeding black-throated blue warblers (Dendroica caerulescens): implications for population dynamics. Journal of Animal Ecology 65: 183-195.

IMS, R. A. \& HJermanN, D. Ø. 2001. Condition-dependent dispersal. En: Clobert, J., Danchin, E., Dhondt, A. A. \& Nichols, J. D. (Eds.), Dispersal. Oxford University Press, New York, pp. 203-216.

KINDVALL, O. \& AHLÉN, I. 1992. Geometrical factors and metapopulation dynamics of the bush cricket, Metrioptera bicolor Philippi (Orthoptera: Tettigoniidae). Conservation Biology 6: 520-529. 
KOSIŃSKI, Z. \& WINIECKI, A. 2004. Nest-site selection and niche partitioning among the great spotted woodpecker Dendrocopos major and middle spotted woodpecker Dendrocopos medius in riverine forests of Central Europe. Ornis Fennica 81: 145156.

KOSSENKO S. M. 2003. A study of mechanisms underlying habitat fragmentation effects on the middle spotted woodpecker Picoides medius: a progress report. En: Pechacek, P. \& d'Oleire-Oltmanns, W. (Eds.), International Woodpecker Symposium. Forschungs-bericht, 48 Nationalparkverwaltung Berchtesgaden, Berchtesgaden, pp. 97-103.

Kossenko S. M. \& KAYgorodova, E. Y. 2001. Effect of habitat fragmentation on distribution, density and breeding performance of the middle spotted woodpecker Dendrocopos medius in the Nerussa-Desna woodland. Entomological Review 81: S161-S166.

Kossenko, S. M. \& Kaygorodova, E. Y. 2007. Reproduction of the middle spotted woodpecker Dendrocopos medius in the Nerussa-Desna woodland, SW Russia, with particular reference to habitat fragmentation, weather conditions and food supply. Ardea 95: 177-189.

Krams, I., Cirule, D., Krama, T., Hukkanen, M., Rytkonen, S., Yezhova, T., Rantala, M. J. \& TUMmeleHt, L. 2010. Effects of forest management on haematological parameters, blood parasites, and reproductive success of the Siberian tit (Poecile cinctus) in northern Finland. Annales Zoologici Fennici 47: 335-346.

KREBS, C. J. 2001. Ecology: the experimental analysis of distribution and abundance. 5th ed. Benjamin/Cummings, San Francisco.

Lambin, X., Aars, J. \& Piertney, S. B. 2001. Dispersal, intraspecific competition, kin competition and kin facilitation: a review of the empirical evidence. En: Clobert, J., Danchin, E., Dhondt, A. A. \& Nichols, J. D. (Eds.), Dispersal. Oxford University Press, New York, pp. 110-122.

LAmpila, P., MönkKönen, M. \& DesRochers, A. 2005. Demographic responses by birds to forest fragmentation. Conservation Biology 19: 1537-1546. 
Lens, L., Van Dongen, S., Norris, K., Guitiru, M. \& Matthysen, E. 2002. Avian persistence in fragmented rainforest. Science 298: 1236-1238.

LINDENMAYER, D. B. \& FISCHER, J. 2006. Habitat fragmentation and landscape change: an ecological and conservation synthesis. Island Press, Washington.

LoIDI, J. 2005. The Cantabrian-Atlantic oak and beech forests: human influence throughout history. Botanika Chronika 18: 161-173.

LUCK, G. W. 2003. Differences in the reproductive success and survival of the rufous treecreeper (Climacteris rufa) between a fragmented and unfragmented landscape. Biological Conservation 109: 1-14.

luis-Calabuig, E., Tárrega, R., Calvo, L., Marcos, E. \& Valbuena, L. 2000. History of landscape changes in northwest Spain according to land use and management. En: Trabaud, L. (Ed.), Life and Environment in the Mediterranean. Wit Press, Southampton, pp. 43-86.

Maldonado, J., Sainz, H., SÁnchez, R. \& Xandri, P. 2001. Distribución y estado de conservación de los bosques españoles: un análisis de las carencias en la red de territorios protegidos. En: Camprodón, J. \& Plana, E. (Eds.), Conservación de la biodiversidad y gestión forestal: su aplicación en la fauna vertebrada. Universitat de Barcelona, Barcelona, pp. 101-117.

Martin, K., Aitken, K. E. H. \& Wiebe, K. L. 2004. Nest sites and nest webs for cavitynesting communities in the interior British Columbia, Canada: nest characteristics and niche partitioning. Condor 106: 5-19.

MichaleK, K. G. \& WinkLER, H. 2001. Parental care and parentage in monogamous great spotted woodpeckers (Picoides major) and middle spotted woodpeckers ( $P$. medius). Behaviour 138: 1259-1285.

MikusińskI, G., GromadzkI, M. \& ChYLARECKI, P. 2001. Woodpeckers as indicators of forest bird diversity. Conservation Biology 15: 208-217.

Mollanen, A., SMith, A. T. \& HANSKI, I. 1998. Long-term dynamics in a metapopulation of the American pika. The American Naturalist 152: 530-542. 
Mortelliti, A., Amori, G. \& BoitANI, L. 2010. The role of habitat quality in fragmented landscapes: a conceptual overview and prospectus for future research. Oecologia 163: 535-547.

MuRCIA, C. 1995. Edge effects in fragmented forests: implications for conservation. Trends in Ecology and Evolution 10: 58-62.

NAEf-DAenzeR, B., WidMer, F. \& Nuber, M. 2001. Differential post-fledging survival of great and coal tits in relation to their condition and fledging date. Journal of Animal Ecology 70: 730-738.

Onrubia, A., Robles, H., Salas, M., González-Quirós, P. \& Olea, P. P. 2003. Pico mediano, Dendrocopos medius. En: Martí, R. \& del Moral, J. C. (Eds.), Atlas de las aves reproductoras de España. Dirección General de Conservación de la NaturalezaSociedad Española de Ornitología, Madrid, pp. 358-359.

Onrubia, A., Robles, H., Salas, M., González-Quirós, P. \& Olea, P. P. 2004. Pico Mediano, Dendrocopos medius. En: Madroño, A., González, C. \& Atienza, J. C. (Eds.), Libro Rojo de las aves de España. Dirección General para la Biodiversidad-SEO/BirdLife, Madrid, pp. 304-307.

PASINELLI, G. 2000. Oaks (Quercus sp.) and only oaks? Relations between habitat structure and home range size of the middle spotted woodpecker (Dendrocopos medius). Biological Conservation 93: 227-235.

PASINELLI, G. 2003. Dendrocopos medius Middle Spotted Woodpecker. BWP Update 5: 49-99.

PAsinelLI, G. 2007. Nest site selection in middle and great spotted woodpeckers Dendrocopos medius \& D. major: implications for forest management and conservation. Biodiversity and Conservation 16: 1283-1298.

Pasinelli, G. \& HegelbaCH, J. 1997. Characteristics of tress preferred by foraging middle spotted woodpecker Dendrocopos medius in northern Switzerland. Ardea 85: 203209.

Pasinelli, G., Hegelbach, J. \& Reyer, H. U. 2001. Spacing behavior of the middle spotted woodpeckers in central Europe. Journal of Wildlife Management 65: 432-441. 
Pellet, J., Fleishman, E., Dobkin, D. S., Gander, A. \& Murphy D. D. 2007. An empirical evaluation of the area and isolation paradigm of metapopulation dynamics. Biological Conservation 136: 483-495.

PenAs, A. 1995. Bioclimatología y vegetación. En: Gallego, E., Alonso, E. \& Penas, A. (Coord.), Atlas del medio natural de la provincia de León. Instituto Tecnológico Geominero de España-Diputación de León, Madrid, pp. 19-40.

Penas, A., llamas, F., Pérez-Morales, C. \& Acedo, C. 1997. A new species of Quercus L. (Fagaceae) from NW Spain. Botanica Helvetica 107: 75-82.

Penteriani V. \& Delgado M. M. 2009. Thoughts on natal dispersal. Journal of Raptor Research 43: 90-98.

PetTersson, B. 1983. Foraging behaviour of the middle spotted woodpecker Dendrocopos medius in Sweden. Holarctic Ecology 6: 263-269.

Pettersson, B. 1985. Extinction of an isolated population of the middle spotted woodpecker Dendrocopos medius (L.) in Sweden and its relation to general theories on extinction. Biological Conservation 32: 335-353.

Porneluzi, P. A. \& FAABORG, J. 1999. Season-long fecundity, survival, and viability of ovenbirds in fragmented and unfragmented landscapes. Conservation Biology 13: 1151-1161.

Power, M. E., Tilman, D., Estes, J. A., Menge, B. A., Bond, W. J., Mills, L. S., Daily, G., CAstilla, J. C., LubChenco, J. \& Paine, R. T. 1996. Challenges in the quest of keystones. Bioscience 46: 609-620.

Roberge, J. M. \& ANGelSTAM, P. 2006. Indicator species between resident forest birds - A cross-regional evaluation in northern Europe. Biological Conservation 130: 134-147.

Robinson, S. K., Thompson III, F. R., Donovan, T. M., Whitehead, D. R. \& FaAborg J. 1995. Regional forest fragmentation and the nesting success of migratory birds. Science 267: 1987-1990.

RoBles, H. 2004. Distribución y estrategias de la vida del pico mediano Dendrocopos medius en una población fragmentada. El papel de la estructura del hábitat. Tesis doctoral, Universidad de León, León. 
Robles, H. \& OleA, P. P. 2003. Distribución y abundancia del pico mediano (Dendrocopos medius) en una población meridional de la Cordillera Cantábrica. Ardeola 50: 275280.

Robles, H., Ciudad, C., Vera, R., Olea, P. P., Purroy, F. J. \& Matthysen, E. 2007a. Sylvopastoral management and conservation of the middle spotted woodpecker at the south-western edge of its distribution range. Forest Ecology and Management 242: 343-352.

Robles, H., Ciudad, C., Vera, R. \& Baglione, V. 2007b. No effect of habitat fragmentation on post-fledging, first-year and adult survival in the middle spotted woodpecker. Ecography 30: 685-694.

Saccheri, I., Kuussaari, M., Kankare, M., Vikman, P., Fortelius, W. \& Hanski, I. 1998. Inbreeding and extinction in a butterfly metapopulation. Nature 392: 491-494.

SIMBERLOFF, D. 1998. Flagships, umbrellas, and keystones: is single species management passé in the landscape era? Biological Conservation 83: 247-257.

StAmps, J. A., BueChNer, M. \& KRISHnAN, V. V. 1987. The effects of edge permeability and habitat geometry on emigration from patches of habitat. American Naturalist 129: 533-552.

TABARELLI, M. \& GASCON, C. 2005. Lessons from fragmentation research: improving management and policy guidelines for biodiversity conservation. Conservation Biology 19: 734-739.

Tárrega, R., Calvo, L., Marcos, E. \& TaboadA, A. 2006. Forest structure and understory diversity in Quercus pyrenaica communities with different human uses and disturbances. Forest Ecology and Management 227: 50-58.

THOMAS, C. D. \& HARRISON, S. 1992. Spatial dynamics of a patchily distributed butterfly species. Journal of Animal Ecology 61: 437-446.

Thomas, C. D., Thomas, J. A. \& WARREN, M. S. 1992. Distribution of occupied and vacant butterfly habitats in fragmented landscapes. Oecologia 92: 563-567.

Travis, J. M. J. \& DYthaM, C. 1999. Habitat persistence, habitat availability and the evolution of dispersal. Proceedings of the Royal Society of London B 266: 723-728. 
VAn Dyck, H. \& BaguetTe M. 2005. Dispersal in fragmented landscapes: routine or special movements? Basic and Applied Ecology 6: 535-545.

Vega Rivera, J. H., Rappole, J. H., McShea, W. J. \& HaAs, C. A. 1998. Wood thrush postfledging movements and habitat use in northern Virginia. Condor 100: 69-78.

Villard, M.-A., TrZCinski, M. K. \& Merriam, G. 1999. Fragmentation effects on forest birds: relative influence of woodland cover and configuration on landscape occupancy. Conservation Biology 13: 774-783.

WAtKinson, A. R. \& SUtherLAND, W. J. 1995. Sources, sinks and pseudo-sinks. Journal of Animal Ecology 64: 126-130.

Wheelwright, N. T. \& Templeton, J. J. 2003. Development of foraging skills and the transition to independence in juvenile savannah sparrows. Condor 105: 279-287.

White, J. D., Gardali, T., Thompson III, F. R. \& FAaborG, J. 2005. Resource selection by juvenile Swainson's thrushes during the post-fledging period. Condor 107: 388-401.

WiLcoX, B. A. \& MURPhY, D. D. 1985. Conservation strategy: the effects of fragmentation on extinction. American Naturalist 125: 879-887.

YodA, K., KOHNO, H. \& NAITO, Y. 2004. Development of flight performance in the brown booby. Proceedings of the Royal Society of London B 271: S240-S242.

Yoder, J. M., MARSChall, E. A. \& SWANSON, D. A. 2004. The cost of dispersal: predation as a function of movement and site familiarity in ruffed grouse. Behavioral Ecology 15: 469-476.

ZANetTe, L., Doyle, P. \& Trémont, S. M. 2000. Food shortage in small fragments: evidence from an area-sensitive passerine. Ecology 81: 1654-1666. 
$C^{2}{ }^{2}$ in a Whe

\section{CAPÍTULO I - DEMOGRAFÍA}

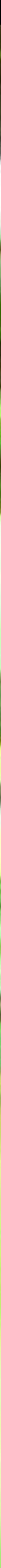




\title{
DEMOGRAPHIC RESPONSES OF MIDDLE SPOTTED WOODPECKERS (DENDROCOPOS MEDIUS) TO HABITAT FRAGMENTATION
}

\begin{abstract}
We examined demographic responses of middle spotted woodpeckers (Dendrocopos medius) to habitat fragmentation in an $880-\mathrm{km}^{2}$ study area in the Cantabrian Mountains (northwest Spain), 2000-2005. We used a set of reproductive parameters to examine 26-72 nests of 10-14 habitat patches. Fifty-nine of 72 nests $(81.9 \%)$ were successful (i.e. at least one fledgling was produced). Average clutch size was 5.1. Seventy of 94 hatchlings (74.4\%) survived to fledging. Mean number of fledgling for successful nests was 3.1, average fledgling mass $50.6 \mathrm{~g}$, and mean fledging date was 21 June. Generalized linear mixed models showed no significant correlations between patch sizes and any of the reproductive parameters, which suggests that habitat fragmentation did not increase nest predation pressure or reduce food in small habitat patches during the breeding season. In 33 habitat patches inspected (4.2 years on average), 190 of 228 territorial males (83.8\%) were paired. Pairing success varied strongly across years $(77.1 \%-97.4 \%)$ and was lower in smaller and more isolated patches. Low pairing success of birds in isolated patches may be associated to a disruption in connectivity between habitat patches. On the other hand, the presence of unpaired males in small patches with low numbers of territories suggests that females may use the abundance of conspecifics as an indicator of habitat quality when deciding to mate.
\end{abstract}

\section{RESPUESTAS DEMOGRÁFICAS DEL PICO MEDIANO (DENDROCOPOS MEDIUS) A LA FRAGMENTACIÓN DEL HÁBITAT}

RESUMEN.- Examinamos las respuestas demográficas del pico mediano (Dendrocopos medius) a la fragmentación del hábitat en un área de estudio de $880 \mathrm{~km}^{2}$ de la Cordillera Cantábrica (noroeste de España) entre 2000 y 2005. Usamos una serie de parámetros reproductivos para examinar 26-72 nidos en 10-14 parches de hábitat. Cincuenta y nueve de 72 nidos (81.9\%) fueron exitosos (i.e. al menos un volantón fue producido). El tamaño de puesta promedio fue 5.1 huevos. Setenta de 94 pollos (74.4\%) sobrevivieron desde la eclosión a la fecha de vuelo. El número medio de volantones por nido exitoso fue 3.1, el peso promedio de los volantones fue 50.6 gramos y la fecha media de vuelo fue el 21 de junio. Modelos lineales generalizados mixtos no mostraron correlaciones significativas entre el tamaño de los parches y los parámetros reproductivos, lo que sugiere que la fragmentación del hábitat no incrementó la presión de depredación ni redujo el alimento en los parches de hábitat pequeños durante la estación de cría. En 33 parches de hábitat inspeccionados (4.2 años en promedio), 190 de los 228 machos territoriales (83.8\%) estuvieron emparejados. El éxito de emparejamiento varió fuertemente entre años ( $77.1 \%$ - 97.4\%) y fue más bajo en los parches más pequeños y aislados. El bajo éxito de emparejamiento en parches aislados puede estar asociado a una disrupción en la conectividad entre los parches de hábitat. Por otro lado, la presencia de machos no emparejados en parches pequeños con bajos números de territorios sugiere que las hembras podrían usar la abundancia de individuos coespecíficos como un indicador de la calidad del hábitat cuando deciden aparearse. 


\section{INTRODUCTION}

Habitat loss and fragmentation have been among the most important factors in the decline of many forest bird populations (e.g. Carlson \& Aulén 1992, Burke \& Nol 1998, Walters et al. 1999, Lens et al. 2002, Luck 2003). In addition to the effects strictly from habitat loss, habitat fragmentation reduces the size of individual patches and increases the distance between them, and also increases the amount of edge habitat in the landscape (Saunders et al. 1991, Stephens et al. 2003). These habitat changes can lead to a decline in bird populations by negatively affecting their demographic components (e.g. Carlson \& Aulén 1992, Donovan et al. 1995, Walters et al. 1999, Luck 2003). Despite this, the underlying demographic causes of population declines are poorly understood (Lampila et al. 2005). A better knowledge of the underlying mechanisms involved in demographic changes in bird populations as a consequence of habitat fragmentation is essential for establishing effective management measures for bird conservation (Lampila et al. 2005).

According to Lampila et al. (2005), habitat fragmentation mainly affects demographic parameters in three ways. First, nest predation and brood parasitism ("nest predation-parasitism hypothesis") have been identified as important mechanisms that can negatively affect nesting success and adult survival in fragmented landscapes (Stephens et al. 2003, Lampila et al. 2005). Second, habitat loss and fragmentation may lead to a reduction of critical resources (e.g. nest sites or food) in small habitat patches (e.g. Burke \& Nol 1998), because smaller patches are less likely to have critical resources than larger ones ("resource concentration hypothesis"; Root 1973, Lampila et al. 2005). Consequently, a negative effect on the demographic parameters associated with food or nest-site availability (e.g. clutch size, fledgling number and mass, pairing success) may be expected (e.g. Burke \& Nol 1998, Luck 2003). Last, increasing the distance among the remaining habitat patches may reduce the connectivity between them ("connectivity disruption hypothesis"). In this sense, a reduction of male pairing success in highly isolated habitat patches may be expected, because these patches may be less accessible to potential mates (Cooper \& Walters 2002). 
In addition to the hypotheses described above, other intrinsic factors may affect the demography of bird populations. Because habitat loss and fragmentation often lead to a reduction in the number of territories and breeding densities in the remaining habitat patches (e.g. Matthysen 1999), these changes may influence some of the demographic components in birds. For example, the lower pairing success observed in relation to habitat fragmentation may also be attributable to female birds using the abundance of territorial males as an index of habitat quality ("conspecific attraction hypothesis"; Villard et al. 1993).

We examined the demographic responses of the middle spotted woodpecker (Dendrocopos medius; hereafter "woodpecker") to habitat fragmentation. In particular, we examined correlative relationships between a set of habitat-patch characteristics (e.g. patch size and isolation, habitat quality) and intrinsic factors (territory number and density), and several demographic parameters associated with the nest predation-parasitism hypothesis (nesting success), resource concentration hypothesis (clutch size, nestling survival, fledgling number and mass, pairing success) and connectivity disruption hypothesis (pairing success). The woodpecker is a resident primary cavity-nester associated with old deciduous forests of the western Palaeartic (Pasinelli 2000, 2003). Habitat loss and fragmentation is a serious threat to the persistence of its populations (Müller 1982, Pettersson 1985, Pasinelli 2003). In deciduous forests, the species has been shown to be an excellent indicator of avian species richness and abundance (Roberge \& Angelstam 2006). Understanding the effects of habitat fragmentation on the demographic parameters of woodpeckers may also have implications for conservation of other European forest birds.

\section{METHODS}

\subsection{Study species and area}

The woodpecker is a medium-sized ( $\sim 55 \mathrm{~g}$ ), forest specialist mainly associated with old oak forests of the western Palaearctic (Pasinelli 2000, 2003). Its social system is characterized by monogamy (Michalek \& Winkler 2001) and territoriality in spring (Pasinelli et al. 2001). Both parents share breeding duties (Michalek \& Winkler 2001). Each year they build a new cavity and raise a single brood (Pasinelli 2001, 2003). 
From 2000 to 2005, we recorded data on demographic parameters of the woodpecker in an $880-\mathrm{km}^{2}$ study area located in the Cantabrian Mountains, northwest Spain (centered on $42^{\circ} 44^{\prime} \mathrm{N}, 5^{\circ} 1^{\prime} \mathrm{W}$ ), which is the southwestern edge of its distributional range (Pasinelli 2003). In this area, woodpeckers occupy oak (Quercus spp.) dehesas, a traditional sylvopastoral agricultural unit that is composed of old oaks interspersed with pasture, and mature oak forests while avoiding highly degraded oak forests and other forested habitats (Onrubia et al. 2004, Robles et al. 2007a). Potential breeding-habitat patches (i.e. oak dehesas and mature oak forests) cover $\sim 7 \%$ of the area. The remaining area is composed of other forested habitats made up of Pinus pinaster, P. sylvestris, Fagus sylvatica, Populus spp., Salix spp., Fraxinus spp., Q. rotundifolia and nonforest habitats (pastures, scrublands, cereal croplands, urban, rocky areas). On the basis of observations of color-banded individuals, we found that woodpeckers do not include more than one habitat patch in their territories (Robles et al. unplubl. data).

\subsection{Demographic parameters}

We recorded data on pairing success of the woodpeckers from 33 habitat patches (6-874 ha, mean $\pm \mathrm{SE}=92.9 \pm 26.9$ ha) inspected 4.2 years, on average, between 2000 and 2005. Because of time restrictions, nine patches (61-275 ha) could not be fully surveyed every year but $\geq 50 \%$ of their surface were inspected each year. In addition, approximately $300-450$ ha of the largest patch ( 874 ha) were surveyed every year. Habitat patches were monitored four to six times from the start of pair formation in February to early March until the beginning of egg laying in early May, which coincided with the peak of intraspecific aggression (Pasinelli et al. 2001) and detectability in this species (Kosiński et al. 2004). "Kweek" and rattle calls (see Pasinelli 2003) were played back to locate territory owners. Once woodpeckers were detected, we stopped the playback to avoid attracting birds from nearby territories (Kossenko \& Kaygorodova 2001). Woodpeckers were followed and signs of activity (visual and auditory) and intraspecific interactions were recorded on 1:4000-1:10000 scale maps (Robles \& Olea 2003). Two birds were considered paired if they were observed, on at least three different visits, foraging or resting together $(<30 \mathrm{~m})$ and with no aggressive 
interactions; excavating nesting holes; copulating; or displaying prior to copulating. Additional visits were made during the breeding season (early May to early July) to confirm the pairing status of birds. No birds classified as unpaired during the prebreeding period were seen with a mate in the breeding season, and woodpeckers classified as paired at that time were observed either breeding or accompanied by the mate during the breeding season (see below). In some cases, one to three woodpeckers were observed visiting to some patches only once or twice. Subsequent visits were made to confirm territorial settlement and pairing status in these patches, but no birds were found despite intensive searches (up to nine visits were made). These "transient" birds occupying temporally vacant patches (Robles \& Olea 2003), and "floaters" wandering through the territories of other owners, were excluded from the analyses of pairing success (i.e. only territorial birds were included).

In a subsample of habitat patches, exhaustive searches were done to locate as many nests as possible during the breeding season (Table 1). Seventy-four nests were found during the nest-building, egg-laying and incubation, and nestling periods. Nesting success could not be assessed in two breeding cavities with nestlings because of logistic and time restrictions. Pairs were scored as successful if they produced fledglings or large nestlings (assessed from changes in the begging calls of the young; see Pasinelli 2001, 2003) or unsuccessful if they failed before producing large nestlings.

In a subsample of accessible nests, clutch size, nestling survival (proportion of hatchlings that fledged), and fledgling number were estimated by using a dentist's mirror and a lamp (Table 1). One case in which the female disappeared during the laying period was excluded of clutch-size analyses. The number of hatchlings was determined by daily visits to the nests when hatching date approached. Fledglings were counted three to eight days before fledging. We checked some nests again before fledging but did not find any differences in brood sizes. Because we found no dead young inside the nest after fledging ( $n=25$ inspected nests), the number of large nestlings was assumed to be an adequate estimation of fledgling number.

In 37 accessible nests, one to eight days before fledging, we cut a hole into the nest chamber, weighed the nestlings and individually color banded them, and then returned them to the nest and closed the hole. Parents brought food normally the 
following days, and all the nestlings survived to fledging date. A similar method has been used successfully in other cavity nesters, such as the lesser spotted woodpecker (D. minor; Wiktander et al. 2001), the black-backed woodpecker (Picoides arcticus; see Ibarzabal \& Tremblay [2006] and references therein) or the European nuthatch (Sitta europaea; Pravosudov 1993). Data from one nest inspected in the middle stage of the nestling period were excluded from the analyses of fledgling number and mass, because we did not know whether all the birds fledged. Nests were monitored daily to determine the fledging date. In inaccessible nests, fledging date was estimated as the day when neither begging calls of the nestlings nor feeding by parents was observed (Pasinelli 2001).

Table 1. Demographic parameter (percentage of successful or mean \pm SE and ranges) of middle spotted woodpeckers examined from 2000 to 2005 in the Cantabrian Mountains (NW Spain). Numbers of patches examined are given in parentheses. See text for explanation of demographic parameters.

\begin{tabular}{lcccc}
\hline Parameters & Study years & Sample sizes & Successful (\%) & \\
\hline Paring success & $2000-2005$ & 228 males (33) & 83.3 \\
Nesting success & $2000-2005$ & 72 nests (14) & 81.9 \\
Nesting survival & $2002-2005$ & 26 nests (10) & $74.4 \%$ of 94 hatchlings & \\
& & & Mean \pm SE & Range \\
\hline Clutch size & $2002-2005$ & 40 nests (12) & $5.1 \pm 0.1$ & $3-7$ \\
Fledgling number & $2001-2005$ & 40 nests (13) & $3.1 \pm 0.2$ & $1-5$ \\
Fledgling mass & $2001-2005$ & 36 nests (13) & $50.6 \pm 0.8$ g & $39.3-59.0$ \\
Fledgling date & $2000-2005$ & 56 nests (13) & $21 \pm 1$ June & 8 June to 13 July \\
\hline
\end{tabular}

\subsection{Habitat variables and intrinsic factors}

Habitat patches (i.e. oak dehesas and mature oak forests, but no other type of forests; see above) were determined from aerial photographs of the Junta de Castilla y León $(2001,2002,2004)$, with verifications in the field. Patch sizes (SIZE) were calculated using ArcGIS 8.1 (ESRI, <www.esri.com>). The proportion of open habitat (vS forested habitat) in contact with the perimeter of the patches (OPENEDGE) was calculated, because the type of edge habitat may affect nest-predation responses (Chalfoun et al. 2002). Distance from nests to nearest patch edge (DISTEDGE) was also calculated to examine the potential effect of edge on reproductive success. 
No other woodpecker populations have been found to the south, east, or west of the study area, but the population continues to the north in the Cantabrian Mountains. Thus, all potential habitat patches within the study area, and a 5-km-wide zone around the north edge, were inspected at least once a year to provide adequate estimations of patch isolation. Several measures of isolation were calculated:

Regional isolation.- Because of the presence of additional populations to the north, north-south coordinates were calculated as a general estimation of regional isolation (RI) (see Matthysen [1999] for a similar study of European nuthatches).

Proximity index.- The proximity index (PROX) available in FRAGSTATS, version 3.3 (McGarigal et al. 2002) was calculated as follows:

$$
\operatorname{PROX}=\sum_{i}\left(s_{i} / d_{i}^{2}\right)
$$

where $s_{i}$ is the size of the patch $i$ and $d_{i}$ is the distance from the focal patch to the patch i (including all habitat patches occupied by woodpeckers within the study area and the 5-km-wide zone around the northern edge). A higher index value indicates a lower degree of isolation (Gustafson \& Parker 1992; see Matthysen [1999] for a similar index).

Distance to nearest source.- All woodpeckers in patches with at least four territories were paired (see below). Therefore, only patches with at least four territories were considered "sources", and the distance to the nearest source (S4) was calculated.

Several measures of habitat structure were recorded. Habitat patches were classified as dehesas or mature forests depending on the type of sylvopastoral management (SYMA) (Robles et al. 2007a). Previous analyses in a smaller area within the study area did not show a significant influence of the sylvopastoral management scheme on nesting success and fledgling number (Robles et al. 2007a). Potential foraging and cavity-tree densities were calculated by establishing a network of 0.04-ha circular plots $100 \mathrm{~m}$ apart (Robles et al. 2007a) in the areas occupied by woodpeckers. We calculated the density of large oaks ( $\geq 37 \mathrm{~cm}$ diameter at breast height [DBH], measured at $1.3 \mathrm{~m}$ above ground) as an estimate of foraging tree availability (FORAG), and the density of oaks $\geq 22 \mathrm{~cm} \mathrm{DBH}$ that were dead, decaying, or with holes as an 
estimation of nesting tree availability (NEST) (Robles et al. 2007a). Both metrics of tree density have been shown to influence territorial settlement (Robles et al. 2007a) and size of home ranges in the spotted woodpecker (Pasinelli 2000) and may affect the birds' demographic variables. Nevertheless, previous analyses within the study area have not shown a significant influence of these tree densities on fledgling number (Robles et al. 2007a).

The number and density of territories were calculated to assess the potential influence of conspecific attraction on pairing success of woodpeckers. In the habitat patches where the entire area was inspected, the number and density of territories were calculated each year. In the 10 patches where the entire area was not inspected every year (see above), these parameters were calculated for at least one year on the basis of at least three visits, which was sufficient to accurately estimate breeding density (Kosiński et al. 2004).

\subsection{Statistical analyses}

The relationship between demographic parameters and the habitat variables were analyzed using generalized linear mixed models (GLMMs) fitted with the glmmPQL function from MASS library in R statistical software (<www.R-project.org $>$ ). Mixed models allow both fixed and random terms to be fitted. Random term in our models take into account multiple measurements within the same patches (Shall 1991). Thus, patch identity was fitted as a random term. Different explanatory variables were fitted as fixed terms in the models according to their potential influence on the demographic parameters. Year, patch size (SIZE) and habitat-structure variables (SYMA, FORAG, NEST) were fitted as fixed terms in all the models, except for fledging-date analyses, in which only year and patch size were included. Isolation variables (S4, PROX, RI) were also included as explanatory variables in the analyses of pairing success. The proportion of open habitat along the edge (OPENEDGE) was fitted as a fixed term in the analyses of pairing and nesting success, and the distance from nests to edgehabitat (DISTEDGE) was fitted in the nesting-success analyses. The number and density of territories were fitted as fixed terms in the pairing-success analyses to test the conspecific attraction hypothesis. 
Generalized linear mixed models allow the use of different error functions according to the structure of the response variables (Venable \& Ripley 2002). Thus, nesting and pairing success were analyzed using a binomial error distribution. We included the stages at which the nests were found (nest building, egg laying and incubation, and nestling periods) as a fixed term to control for their potential influence on the variation in nesting success, but no a significant relationship was found $(P=$ 0.67). Therefore, the data of all the nests were included in the nesting-success analyses. Data from 2005 were not included in the analyses of pairing success, because $\sim 100 \%$ of territories (38 of 39) were occupied by paired woodpeckers. Nestling survival was also analyzed by using a binomial error distribution, in which the number of fledglings was modeled as the response term and the number of hatchlings fitted as the binomial denominator. In the analyses of fledging number (only successful nests) and clutch size, a Poisson error distribution was used. Average fledgling mass and fledging date were assessed by using a Gaussian error distribution. In the fledging mass analyses, brood size and the number of days from observations to fledging date were also introduced as fixed terms.

Explanatory variables were fitted to the data by performing a forward stepwise procedure (e.g. Donázar et al. 1993, Carrete \& Donázar 2005). Highly correlated variables $\left(r_{s} \geq|0.6|\right)$ were not included simultaneously in the same model, to avoid multicolinearity. Each explanatory variable was first tested by considering their linear, quadratic and cubic terms based on a conditional $F$ test. The most significant term was incorporated in the model, and the significance of the remaining variables tested again until no significant variables at the 0.05 level could be added. Interactions of significant terms were assessed.

\section{RESULTS}

\subsection{Pairing success}

Overall, 190 of 228 woodpeckers (83.3\%) obtained a mate. From observations of woodpeckers in nine territories in which the sex of the birds could be determined by experienced observers, unpaired woodpeckers were males. In addition, 12 more birds were classified as males by inexperienced observers. In the remaining 17 cases, sex 
could not be determined because of high vegetation cover, low-light conditions, or elusive birds. We assumed, therefore, that all unpaired territorial woodpeckers were males.

The GLMM analyses of pairing success produced three alternative models because the variables patch size, territory number and PROX were highly correlated $\left(r_{s} \geq 0.6, P\right.$ $<0.001$ ) and, therefore, could not be entered in the same model. Year had a strong influence on pairing success, even excluding the data from 2005 (Table 2). The proportion of paired males increased from $77.1 \%$ in 2000 to $97.4 \%$ in 2005 (annual mean $\pm S E=83.1 \pm 3.2 \%$; Fig. 1 ). In addition to the year effect, the first model included SIZE through its interaction with year as a significant explanatory term (Table 2). Inspections of the parameter estimates suggest a positive relationship between SIZE and pairing success in all years (logit estimates: 0.11-0.16, all $P<0.01$ ) except for 2004, when the estimate was close to zero $(0.003 \pm 0.006, P>0.6)$. The second model included number of territories and its interaction with year as significant explanatory terms (Table 2). Woodpeckers in patches with a higher number of territories had higher probabilities of acquiring a mate. In particular, males occupying habitat patches with only one territory had the lowest annual probability of pairing (63.8\%), whereas territorial males in habitat patches with $\geq 4$ territories were paired every year (Fig. 2). The influence of territory number on pairing success was stronger in 2000-2002 (estimates: 1.70-2.69, all $P<0.05$ ), whereas the parameter estimates in 2003 and 2004 were not significantly different from zero (estimates: $0.91 \pm 0.59$ and $0.20 \pm 0.22$, respectively, $P>0.1$ ). The third model included PROX through its interaction with year as a significant term (Table 2). Similarly to the previous model, PROX had a stronger positive influence on pairing success in 2000-2002 (estimates: 0.31-1.13, $P=0.01-0.09$ ) than in 2003 and 2004 (estimates: $0.05 \pm 0.05$ and $0.02 \pm 0.02$, respectively, $P>0.3$ ). Nevertheless, the raw data (Fig. 3) show that unpaired birds were associated with smaller patches (i.e. with fewer territories) and lower PROX values in all years. Although we have no explanation for the between-year variation, our data show that pairing success was higher in larger and better-connected (i.e. higher PROX values) patches in most, if not all, years. Regional isolation (RI) was marginally significant (estimate $\pm \mathrm{SE}=0.00006 \pm 0.00004, P=0.08$ ) when it was added to the second model, 
but $P$ values were $>0.1$ when they were added to the first and third models. The remaining patch characteristics and territory density had low influence on the probability of pairing (all $P>0.1$ ).

Table 2. Results of GLMM analysis that explain pairing success of middle spotted woodpeckers. Pairing status was examined for 189 territorial males in 32 habitat patches from 2000 to 2004 . A binomial error distribution with a logistic link function was used. Patch identity was included as random term.

\begin{tabular}{lrrr}
\hline & \multicolumn{1}{c}{ df } & \multicolumn{1}{c}{$F$} & \multicolumn{1}{c}{$P$} \\
\hline Model 1 & & & \\
Intercept & 1 and 149 & 2.89 & 0.09 \\
SIZE & 1 and 30 & 1.92 & 0.18 \\
YEAR & 4 and 149 & 3.55 & $<0.01$ \\
SIZE * YEAR & 4 and 149 & 7.71 & $<0.01$ \\
Model 2 & & & \\
Intercept & 1 and 148 & 10.87 & $<0.01$ \\
Number of territories & 1 and 148 & 5.89 & 0.02 \\
YEAR & 4 and 184 & 1.99 & 0.10 \\
Number of territories * YEAR & 4 and 184 & 3.05 & 0.02 \\
Model 3 & & & \\
Intercept & 1 and 149 & 3.09 & 0.08 \\
YEAR & 4 and 149 & 3.85 & $<0.01$ \\
PROX & 1 and 30 & 1.55 & 0.22 \\
YEAR * PROX & 4 and 149 & 2.60 & 0.04 \\
\hline
\end{tabular}

Fig. 1. Annual proportions of paired males. Numbers above the bars are the number of males.
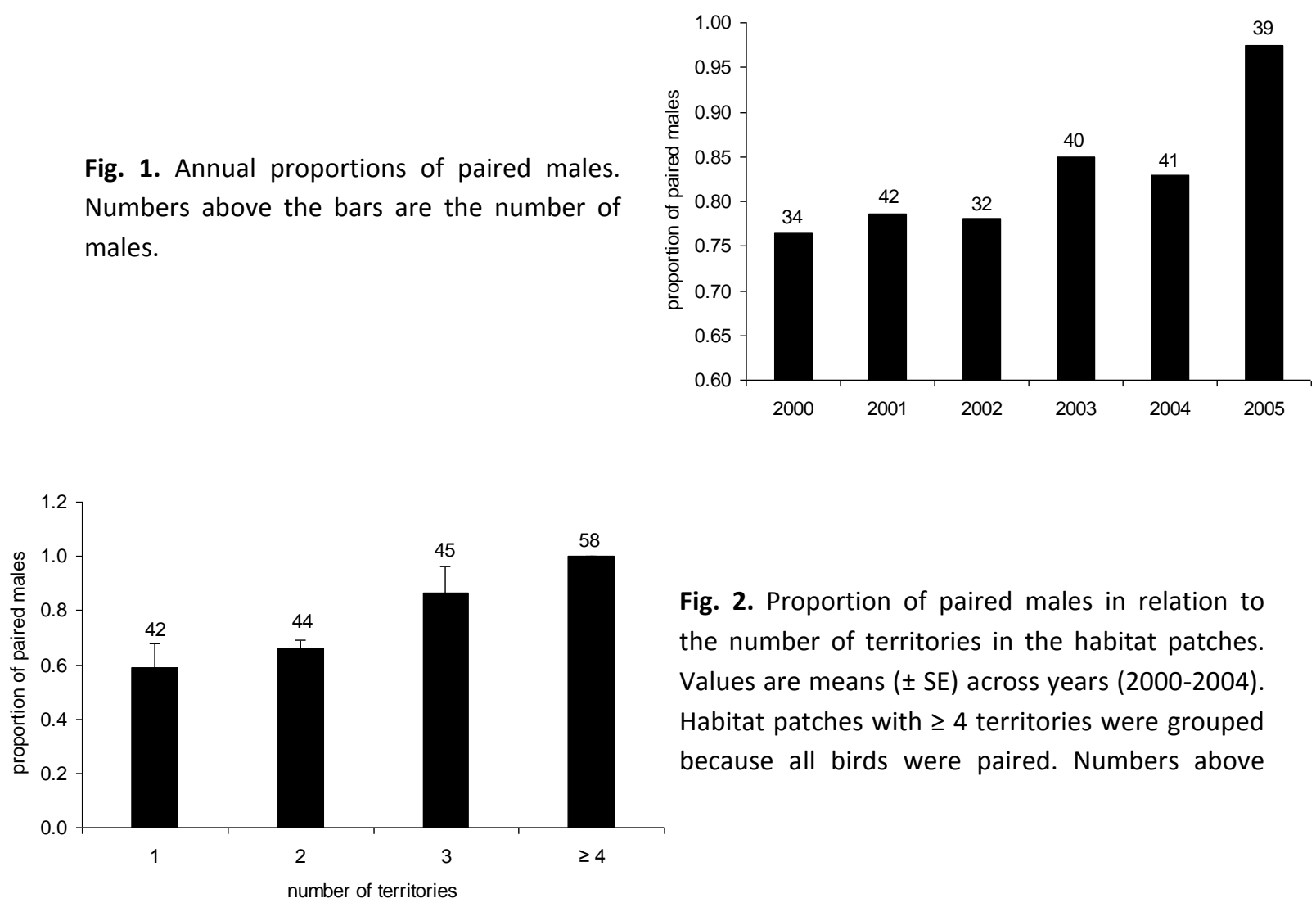

Fig. 2. Proportion of paired males in relation to the number of territories in the habitat patches. Values are means ( \pm SE) across years (2000-2004). Habitat patches with $\geq 4$ territories were grouped because all birds were paired. Numbers above 

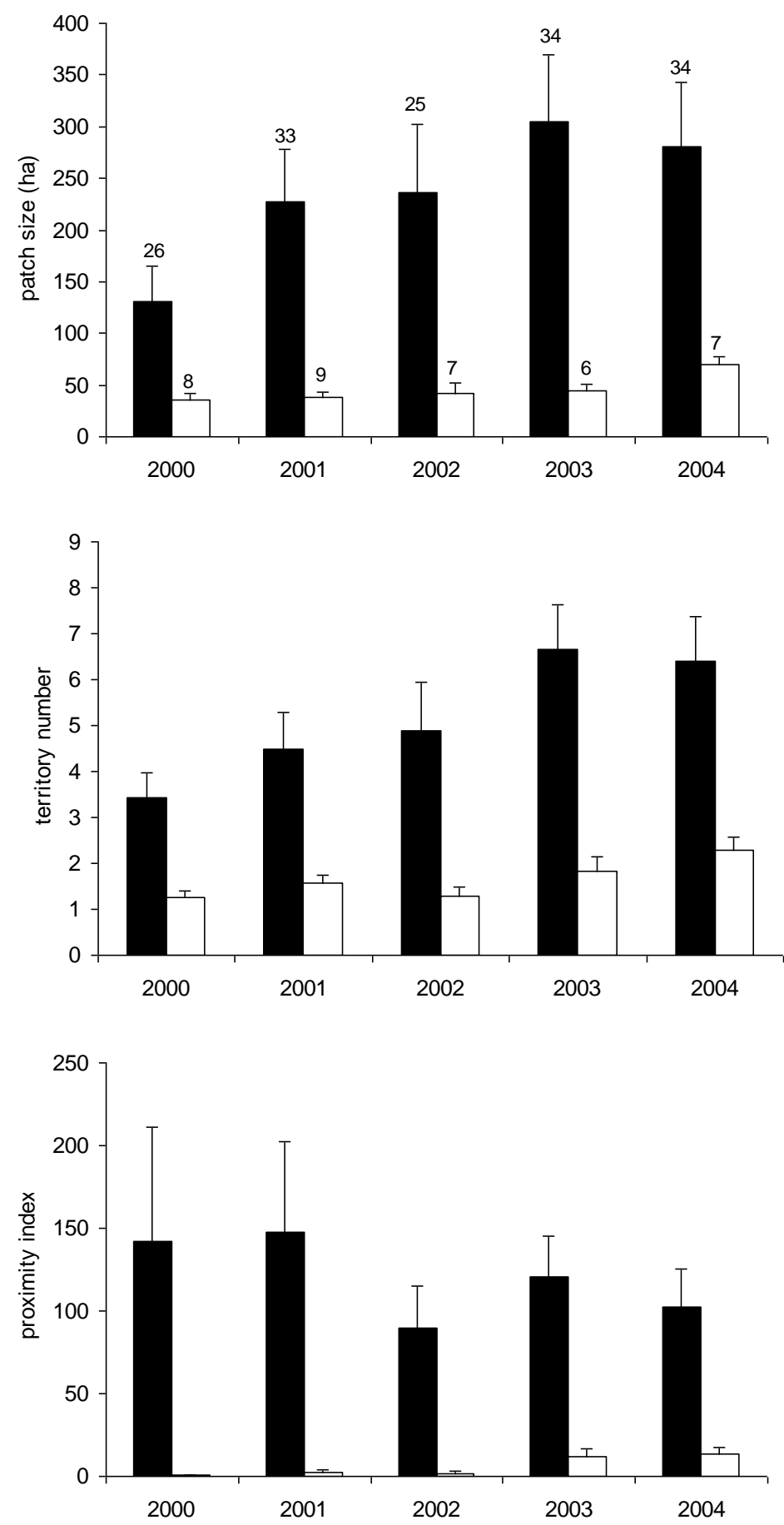

Fig. 3. Average ( $\pm \mathrm{SE}$ ) size, territory number and proximity index in the habitat patches occupied by paired (black bars) and unpaired (white bars) males across the years. Numbers above bars are the number of males. 


\subsection{Reproductive parameters in the nests}

Fifty-nine of 72 nests (82\%) were successful. Causes of breeding failures were determined in some cases. In two cases, females did not lay eggs. These pairs excavated complete nesting holes and were observed defending territories, displaying and copulating, but no eggs were found despite intensive monitoring of the nest during the breeding season. In three cases, the probable cause of breeding failure was the loss of one pair member during the prelaying period (birds displayed and excavated complete nest holes, but no eggs were found), egg-laying period (only one egg was laid) and incubation period (a clutch with seven eggs). In these cases, the remaining member of the pair was seen the following days in the proximity of the nest cavity persistently calling the mate ("kweek call"; see Pasinelli 2003). Another two nests were preyed on by an unknown mammalian carnivore during the end of incubation-hatching period. Low nest-provisioning rates were the possible cause of breeding failure in two nests. Female loss and low feeding rates caused breeding failure in one nest. Causes of breeding failure were unknown in two cases where nestlings were found dead in the breeding cavities. In these cases, no signs of predation were found. In the remaining nest, though a pair was observed around the nest in the breeding season, no food was delivered, and we do not know whether eggs were laid.

Average clutch size was 5.1 eggs (Table 1$)$. Seventy of 94 hatchlings (74.4\%) fledged. Nestling mortality occurred in $46.2 \%$ of the monitored nests $(n=26$; five nests lost one nestling, two lost two nestlings, and another five lost three nestlings). Mean number of fledglings for successful nests was 3.1, average fledgling mass was $50.6 \mathrm{~g}$, and mean fledging date was 21 June (Table 1).

The GLMM analyses failed to find any significant influence of the habitat patch characteristics in all the reproductive parameters examined in the nests. The parameter FORAG had a marginally significant positive influence on nesting success (estimate $\pm \mathrm{SE}=0.02 \pm 0.01, P=0.07$ ). Values for the remaining explanatory variables and analyses were far from significance (all $P>0.1$ ). 


\section{DISCUSSION}

Nest parasitism and predation have been identified as important mechanisms that negatively affect adult survival and reproduction in fragmented habitats (Lampila et al. 2005). Our results, however, did not allow us to confirm the "nest predation-parasitism hypothesis". Nesting success was rather high ( $82 \%$ of nests) and was not strongly affected by variables associated with an increase in predation and parasitism pressures in fragmented habitats (i.e. patch size, proportion of open edge-habitat and distance to edge). Indeed, only two nests $(2.8 \%)$ were depredated, and no nest parasitism was found. The variation in the effect of habitat fragmentation on nesting success among bird species may be explained by the differences in nest sites. Open-nesting birds are often negatively affected by habitat fragmentation because of an increase in predation and parasitism pressures on the nests (e.g. Porneluzi \& Faaborg 1999), but such selection pressures have not been shown to be important mechanisms for reducing nesting success in cavity nesters (see review in Lampila et al. 2005, but see Huhta et al. 2004), because cavities are probably better protected from predators and brood parasites (Matthysen \& Adriaensen 1998). In particular, primary cavity nesters, which usually excavate a new breeding hole each year, such as the woodpecker (Pasinelli 2000,2003 ), are minimally exposed to nest predation (Nilsson et al. 1991, Deng \& Gao 2005).

Following the "resource concentration hypothesis", larger habitat patches likely provide more food and nest sites than smaller ones. Demographic parameters presumably associated with food availability (i.e. clutch size, nestling survival, fledgling number and mass, and possibly nesting success in this population) were not correlated with patch size, which suggests that habitat fragmentation did not reduce food supply in small patches, at least during the breeding season. These results agree with most avian studies (review in Lampila et al. 2005; but see Hinsley et al. 1999) but partly contrast with those of Kossenko (2003), who found significantly higher nestling losses in a woodpecker population in habitat fragments than in a continuous habitat, though most of the losses in the fragments were attributable to nest desertion rather than to low feeding rates. Moreover, potential prey abundance for nestlings was greater in 
fragments than in the continuous habitat in one of the two study years (Kossenko 2003). Therefore, food supply was not reduced as a consequence of fragmentation.

In accordance with the results of Pasinelli (2001), we did not find a significant relationship between the reproductive parameters of the nests and the structure of the habitat (habitat type and densities of potential foraging and cavity trees). Only a weak positive relation $(P=0.07)$ was found between nesting success and the density of potential foraging trees. Nevertheless, the density of these large oaks did not significantly influence the remaining parameters (clutch size, nestling survival, fledging number, and fledgling mass); and given the high nesting success (82\%), these results do not suggest a strong influence of habitat structure on the reproductive output of woodpecker pairs.

According to the "connectivity disruption hypothesis", fewer males in highly isolated habitat patches may pair because these patches may be less easily colonized by potential mates (Dale 2001, Brooker \& Brooker 2002, Cooper \& Walters 2002, Lampila et al. 2005). Woodpeckers in less-isolated patches (high PROX values) had higher probabilities of acquiring a mate, which suggests that a disruption of connectivity may prevent males in highly isolated patches from mating. Removal or translocation experiments are necessary to test this hypothesis (e.g. Cooper $\&$ Walters 2002). However, dispersal is not sex-biased in the middle spotted woodpecker and patch connectivity has little influence on woodpecker dispersal in this study area (Chapter II), suggesting that a disruption in the connectivity is not the mechanism that explains the presence of unpaired territorial males.

Pairing success of woodpecker males was lower in smaller habitat patches. Females may actively avoid pairing with males in small habitat patches because of high pressures of nest predation and brood parasitism (Van Horn et al. 1995, Burke \& Nol 1998) near the edges ("habitat selection hypothesis"; see Villard et al. 1993). However, because distance to edge and proportion of open-edge habitat did not have a significant effect on nesting success or pairing success, this explanation seems unlikely. Thus, an increase in nest predation and parasitism pressures near edges is not an important mechanism influencing pairing success in this population. In fact, Kosiński \& Winiecki (2004) found a preference in woodpeckers for nesting near the edges, which 
is probably related to their foraging behavior. Besides, female dispersers do not prefer large patches to settle in this study area (Chapter II), further suggesting that active avoidance of small patches by females is an unlikely explanation for the low pairing success of woodpeckers in small habitat patches.

Given that woodpeckers are monogamous and that only unpaired territorial males have been observed, a female-biased adult mortality in more fragmented habitats may be expected, as suggested by studies of other bird species (e.g. Gibbs \& Faaborg 1990, Githiru \& Lens 2006). Nevertheless, woodpecker survival is not sex-biased in this area (Robles et al. 2007b).

Another potential factor influencing pairing success of birds is "conspecific attraction" (Smith \& Peacock 1990). Territorial songbirds use the presence and abundance of other conspecifics when deciding where to settle (Dolíguez et al. 2004, Ward \& Schlossberg 2004). Conspecific attraction has been suggested as a potential explanation for the variation in pairing success in fragmented versus continuous habitats in ovenbirds (Seiurus aurocapillus; Villard et al. 1993). According to this hypothesis, females actively prefer to mate with males in patches with a higher abundance of conspecifics. All unpaired woodpeckers were found in small habitat patches with only one to three territories. Thus, females may use the proximity and the number of neighbor territorial conespecifics as an index of quality when deciding on a mate. Consequently, small patches with few neighbors would be judged to be of low quality. In support of this hypothesis, some unpaired males in small habitat patches were visited by potential mates for a few days in the pair-formation season, which suggests that conspecific attraction (or mate selection) is a potential explanation of the low pairing success of males observed in small patches. Besides, female dispersers prefer to settle in high density patches (Chapter II), further supporting the conspecific attraction hypothesis.

\section{REFERENCES}

BROOKER, L. \& BROOKER, M. 2002. Dispersal and population dynamics of the bluebreasted fairy-wrens, Malurus pulcherrimus, in fragmented habitat in western Australian wheatbelt. Wildlife Research 29: 225-233. 
BURKE, D. M. \& NoL, E. 1998. Influence of food abundance, nest-site selection and forest fragmentation on breeding ovenbirds. The Auk 115: 96-104.

CARlson, A. \& G. AulÉn, G. 1992. Territorial dynamics in an isolated white-backed woodpecker Dendrocopos leucotos population. Conservation Biology 6: 450-454.

CARRETE, M. \& DonázAR, J. A. 2005. Application of central-place foraging theory shows the importance of Mediterranean dehesas for the conservation of the cinereous vulture, Aegypius monachus. Biological Conservation 126: 582-590.

Chalfoun, A. D., Thompson III, F. R. \& Ratnaswamy, M. F. 2002. Nest predators and fragmentation: a review and meta-analysis. Conservation Biology 16: 306-318.

COOPER, C. B. \& WALters, J. R. 2002. Experimental evidence of disrupted dispersal causing decline of an Australian passerine in fragmented habitat. Conservation Biology 16: 471-478.

DALE, S. 2001. Female-biased dispersal, low female recruitment, unpaired males, and the extinction of small and isolated bird populations. Oikos 92: 344-356.

DENG, W. H. \& GAO, W. 2005. Edge effects on nesting success of cavity-nesting birds in fragmented forests. Biological Conservation 126: 363-370.

Doligez, B., PÄrt, T., DAnchin, E., Clobert, J. \& Gustafsson, L. 2004. Availability and use of public information and conspecific density for settlement decisions in the collared flycatcher. Journal of Animal Ecology 73: 75-87.

DonÁzar, J. A., Hiraldo, F. \& Bustamante, J. 1993. Factors influencing nest site selection, breeding density and breeding success in the bearded vulture (Gypaetus barbatus). Journal of Applied Ecology 30: 504-514.

Donovan, T. M., Lamberson, R. H., Kimber, A., Thompson III, F. R. \& FaAborg J. 1995. Modelling the effects of habitat fragmentation on source and sink demography of neotropical migrant birds. Conservation Biology 9: 1396-1407.

GIBBS, J. P. \& FAABORG, J. 1990. Estimating the viability of ovenbird and Kentucky warbler populations in forest fragments. Conservation Biology 4: 193-196.

GITHIRU, M. \& LENS, L. 2006. Annual survival and turnover rates of an Afrotropical robin in a fragmented forest. Biodiversity and Conservation 15: 3315-3327. 
GUSTAFSON, E. J. \& PARKER, G. R. 1992. Relationships between landcover proportion and indices of landscape spatial pattern. Landscape Ecology 7: 101-110.

Hinsley, S. A., ROtheRY, P. \& Bellamy, P. E. 1999. Influence of woodland area on breeding success in great tits Parus major and blue tits Parus caeruleus. Journal of Avian Biology 30: 271-281.

Huhta, E., Aho, T., Jäntti, A., Suorsa, P., Kuitunen, M., Nikula, A. \& Hakkarainen, H. 2004. Forest fragmentation increases nest predation in Eurasian treecreepers. Conservation Biology 18: 148-155.

Ibarzabal, J. \& TRemblay, J. A. 2006. The hole saw method for accessing woodpecker nestlings during developmental studies. Annales Zoologici Fennici 43: 235-238.

KOSIŃSKI, Z. \& WINIECKI, A. 2004. Nest-site selection and niche partitioning among the great spotted woodpecker Dendrocopos major and middle spotted woodpecker Dendrodopos medius in riverine forest of Central Europe. Ornis Fennica 81: 145-156.

KosińSKI, Z., KEMPA, M. \& HYBSZ, R. 2004. Accuracy and efficiency of different techniques for censusing territorial middle spotted woodpeckers Dendrocopos medius. Acta Ornithologica 39: 29-34.

KOSSENKO S. M. 2003. A study of mechanisms underlying habitat fragmentation effects on the middle spotted woodpecker Picoides medius: A progress report. In: Pechacek, P. \& d'Oleire-Oltmanns, W. (Eds.), International Woodpecker Symposium. Forschungs-bericht, 48 Nationalparkverwaltung Berchtesgaden, Berchtesgaden, pp. 97-103.

Kossenko S. M. \& KAYgorodova, E. Y. 2001. Effect of habitat fragmentation on distribution, density and breeding performance of the middle spotted woodpecker Dendrocopos medius in the Nerussa-Desna woodland. Entomological Review 81: S161-S166.

Lampila, P., MönkKönen, M. \& DesRochers, A. 2005. Demographic responses by birds to forest fragmentation. Conservation Biology 19: 1537-1546.

Lens, L., Van Dongen, S., Norris, K., Guitiru, M. \& Matthysen, E. 2002. Avian persistence in fragmented rainforest. Science 298: 1236-1238. 
LuCK, G. W. 2003. Differences in the reproductive success and survival of the rufous treecreeper (Climacteris rufa) between a fragmented and unfragmented landscape. Biological Conservation 109: 1-14.

Matthysen, E. 1999. Nuthatches (Sitta europaea: Aves) in forest fragments: demography of a patchy population. Oecologia 119: 501-509.

Matthysen, E. \& Adriaensen, F. 1998. Forest size and isolation have no effect on reproductive success of Eurasian nuthatches (Sitta europaea). The Auk 115: 955963.

McGarigal, K., Cushman, S. A., Neel, M. C. \& Ene, N. 2002. FRAGSTATS: spatial pattern analysis program for categorical maps, version 3.0. University of Massachusetts, Amherst.

MiCHALEK, K. G. \& WinkLER, H. 2001. Parental care and parentage in monogamous great spotted woodpeckers (Picoides major) and middle spotted woodpeckers ( $P$. medius). Behaviour 138: 1259-1285.

MülLER, W. 1982. Die besiedlung der eichenwälder in Kanton Zürich durch den mittelspechts Dendrocopos medius. Der Ornithologische Beobachter 79: 105-119.

NILSSON, S. G., JOHNSON, K. \& TJERNBERG, M. 1991. Is avoidance by black woodpeckers of old nest holes due to predators? Animal Behavior 41: 439-441.

Onrubia, A., Robles, H., Salas, M., González-Quirós, P. \& Olea, P. P. 2004. Pico mediano, Dendrocopos medius. In: Madroño, A., González, C. \& Atienza, J. C. (Eds.), Libro Rojo de las Aves de España. Dirección General para la Biodiversidad-SEO/BirdLife, Madrid, pp. 304-307.

PASINelLI, G. 2000. Oaks (Quercus sp.) and only oaks? Relations between habitat structure and home range size of the middle spotted woodpecker (Dendrocopos medius). Biological Conservation 93: 227-235.

PASINELLI, G. 2001. Breeding performance of the middle spotted woodpecker Dendrocopos medius in relation to weather and territory quality. Ardea 89: 353-361.

PASINELLI, G. 2003. Dendrocopos medius middle spotted woodpecker. BWP Update 5: 49-99. 
Pasinelli, G., Hegelbach, J. \& Reyer, H. U. 2001. Spacing behavior of the middle spotted woodpeckers in central Europe. Journal of Wildlife Management 65: 432-441.

Pettersson, B. 1985. Extinction of an isolated population of the middle spotted woodpecker Dendrocopos medius (L.) in Sweden and its relation to general theories on extinction. Biological Conservation 32: 335-353.

Porneluzi, P. A. \& FAABORG, J. 1999. Season-long fecundity, survival, and viability of ovenbirds in fragmented and unfragmented landscapes. Conservation Biology 13: 1151-1161.

Pravosudov, V. V. 1993. Breeding biology of the Eurasian nuthatch in northeastern Siberia. Wilson Bulletin 105: 475-482.

Roberge, J. M. \& ANGelSTAM, P. 2006. Indicator species between resident forest birds - A cross-regional evaluation in northern Europe. Biological Conservation 130: 134-147.

Robles, H. \& OleA, P. P. 2003. Distribución y abundancia del pico mediano (Dendrocopos medius) en una población meridional de la Cordillera Cantábrica. Ardeola 50: 275280.

Robles, H., Ciudad, C., Vera, R., Olea, P. P., Purroy, F. J. \& Matthysen, E. 2007a. Sylvopastoral management and conservation of the middle spotted woodpecker at the south-western edge of its distribution range. Forest Ecology and Management 242: $343-352$.

Robles, H., Ciudad, C., Vera, R. \& Baglione, V. 2007b. No effect of habitat fragmentation on post-fledging, first-year and adult survival in the middle spotted woodpecker. Ecography 30: 685-694.

Root, R. B. 1973. Organization of a plant-arthropod association in simple and diverse habitats: the fauna of collards (Brassica oleraceae). Ecological Monographs 45: 95120.

Saunders, D. A., Hobbs, R. J. \& Margules, C. R. 1991. Biological consequences of ecosystem fragmentation: a review. Conservation Biology 5: 18-32.

SCHALL, R. 1991. Estimation of generalised linear mixed models with random effects. Biometrika 78: 719-727. 
SMith, A. T. \& PeACOCK, M. M. 1990. Conspecific attraction and the determination of metapopulation colonization rates. Conservation Biology 4: 320-323.

Stephens, S. E., Koons, D. N., Rotella, J. J. \& Willey, D. W. 2003. Effects of habitat fragmentation on avian nesting success: a review of the evidence at multiple spatial scales. Biological Conservation 115: 101-110.

Van Horn, M. A., Gentry, R. M. \& FaAborg, J. 1995. Patterns of ovenbird (Seiurus aurocapillus) pairing success in Missouri forest tracts. The Auk 112: 98-106.

Venables, W. N. \& Ripley, B. D. 2002. Modern applied statistics with S. Fourth edition. Springer, New York.

Villard, M.-A., Martin, P. R. \& Drummond, C. G. 1993. Habitat fragmentation and pairing success in the ovenbird (Seiurus aurocapillus). The Auk 110: 759-768.

Walters, J. R., Ford, H. A. \& CoOper, C. B. 1999. The ecological basis of sensitivity of brown treecreepers to habitat fragmentation: a preliminary assessment. Biological Conservation 90: 13-20.

Ward, M. P. \& SChlossberg, S. 2004. Conspecific attraction and the conservation of territorial songbirds. Conservation Biology 18: 519-525.

WikTANDER, U., OlsSON, O. \& NilsSON, S. G. 2001. Age and reproduction in lesser spotted woodpeckers (Dendrocopos minor). The Auk 118: 624-635. 
CAPÍTULO II - DISPERSIÓN 


\title{
INFLUENCE OF HABITAT QUALITY, POPULATION DENSITY, PATCH SIZE AND CONNECTIVITY ON MULTIPLE DISPERSAL STAGES IN THE MIDDLE SPOTTED WOODPECKER
}

\begin{abstract}
Most dispersal studies, often based on a single dispersal stage (emigration or settlement of juveniles or adults), have not assessed simultaneously the influence of habitat patch size, connectivity and quality. From a conservation perspective, however, the impacts of patch-size reduction may demand different strategies than those of habitat degradation or isolation. Besides, different conditions may influence dispersal at each stage and/or the same conditions may exert different effects on different dispersal stages. We used an information-theoretic approach to examine the influence of habitat quality, population density, patch size and connectivity on multiple dispersal stages of middle spotted woodpeckers (Dendrocopos medius) in fragmented habitats from Spain (2001-2010) and Russia (1997-2006). Patch connectivity and the proportion of deciduous forest in the surrounding matrix had little influence on dispersal. However, patch size, habitat quality and population density had different effects on several dispersal stages. Patch size had little influence on the emigration from the natal patch by juveniles, the settlement of inter-patch young dispersers and breeding dispersal in the Spanish population, but adults in larger patches were more likely to leave their breeding territory in the high populated Russian area. Juveniles from higher quality habitats were more likely to remain in the natal patch, whereas dispersers tended to settle in better quality patches, showing that habitat degradation promoted dispersal. Regardless habitat characteristics, juveniles preferred patches with high population density to settle in, suggesting that conspecific attraction may play a major role in patch colonization. However, population density had low influence on juvenile emigration from the natal patch. Unlike juveniles, habitat quality and population density had low influence on dispersal in adults, which rarely left the breeding patch. Because different conditions influenced each dispersal stage and some conditions had different effects (strong vs limited influence) on several dispersal stages, this study highlights the importance of assessing simultaneously the effects of habitat quality, population density, patch size and connectivity on multiple dispersal stages to establish effective conservation actions of populations and to a better understanding of the dispersal process.
\end{abstract}




\section{INFLUENCIA DE LA CALIDAD DEL HÁBITAT, LA DENSIDAD DE POBLACIÓN, EL TAMAÑO Y LA CONECTIVIDAD DE LOS PARCHES EN MÚLTIPLES ETAPAS DE DISPERSIÓN EN EL PICO MEDIANO}

RESUMEN.- La mayor parte de los estudios sobre dispersión, basados a menudo en un única etapa dispersiva (emigración o asentamiento de juveniles o adultos), no han analizado simultáneamente la influencia del tamaño, la conectividad y la calidad de los parches de hábitat. Desde el punto de vista de la conservación, sin embargo, los impactos derivados de la reducción del tamaño de los parches pueden requerir diferentes estrategias que los derivados de la degradación del hábitat o el aislamiento. Además, diferentes condiciones pueden influir en la dispersión en cada etapa y/o las mismas condiciones pueden ejercer efectos diferentes en las distintas etapas dispersivas. Usamos un enfoque basado en la teoría de la información para examinar la influencia de la calidad del hábitat, la densidad de la población, el tamaño del parche y la conectividad en múltiples etapas dispersivas del pico mediano (Dendrocopos medius) en hábitats fragmentados de España (2001-2010) y Rusia (1997-2006). La conectividad del parche y la proporción de bosque caducifolio en la matriz circundante tuvieron poca influencia en la dispersión. Sin embargo, el tamaño del parche, la calidad del hábitat y la densidad poblacional tuvieron diferentes efectos en las distintas etapas dispersivas. El tamaño del parche tuvo poca influencia en la emigración de los juveniles desde el parche natal, en el asentamiento de los juveniles en dispersión y en la dispersión de cría en la población española, pero los adultos en los parches más grandes tuvieron mayor probabilidad de abandonar sus territorios de cría en el área altamente poblada de Rusia. Los juveniles originarios de los parches de mayor calidad tuvieron más probabilidad de permanecer en el parche natal, mientras que los dispersantes tendieron a asentarse en parches de mejor calidad, mostrando que la degradación del hábitat estimula la dispersión. Al margen de las características del hábitat, los juveniles prefirieron asentarse en los parches con una elevada densidad de población, sugiriendo que la atracción de coespecíficos puede desempeñar un papel clave en la colonización de los parches. A diferencia de los juveniles, la calidad del hábitat y la densidad poblacional tuvieron poca influencia en la dispersión de los adultos, los cuales raramente abandonan el parche de cría. Puesto que diferentes condiciones influyeron en cada etapa dispersiva y algunas condiciones tuvieron diferentes efectos (fuerte vs baja influencia) en las distintas etapas, este estudio remarca la importancia de evaluar simultáneamente los efectos de la calidad del hábitat, la densidad poblacional, el tamaño del parche y la conectividad en las múltiples etapas dispersivas para establecer acciones de conservación efectivas de las poblaciones y para una mejor comprensión del proceso de dispersión. 


\section{INTRODUCTION}

Dispersal is a crucial process influencing individual fitness, gene flow, population dynamics and species distributions (Hanski \& Gilpin 1997, Clobert et al. 2001, Bowler \& Benton 2005). At the population level, immigration may rescue declining or sink populations from extinction (Brown \& Kodric-Brown 1977, Watkinson \& Sutherland 1995), or favour the (re)colonization of empty patches that balances extinctions of other patches in metapopulations (Hanski \& Gilpin 1997). Conversely, high movement rates may increase simultaneous extinctions by synchronizing the dynamics of local populations (Heino et al. 1997). Given the link between dispersal and population dynamics in spatially structured systems, understanding the causes and consequences of dispersal is essential to predict the response of populations to habitat loss and fragmentation (Bowler \& Benton 2005, Kokko \& López-Sepulcre 2006, Lindenmayer \& Fischer 2006, Clobert et al. 2009).

Most previous studies on dispersal have not assessed simultaneously the effects of habitat loss, fragmentation (i.e. habitat subdivision and isolation of the remaining patches) and degradation, despite these spatial processes may have different effects on behaviour. Habitat loss can favour philopatry due to the incremented emigration cost (Travis \& Dytham 1999), whereas habitat isolation associated with fragmentation can either increase or reduce the cost-benefit ratio of dispersal depending on the extinction risk in the remaining patches and the mortality rate during migration (Heino \& Hanski 2001). On the other hand, habitat degradation can promote dispersal to escape adverse conditions such as the scarcity of food resources (Dickinson \& McGowan 2005, Baglione et al. 2006). From a conservation perspective, the impacts of habitat loss and subdivision associated with the reduction in patch sizes may require different strategies than those of habitat degradation or habitat isolation (Lens et al. 2002, Lindenmayer \& Fischer 2006). Management actions within local areas may remediate habitat degradation, whereas the increment of the amount of habitat at the landscape scale may be needed when the reduction in patch size causes severe impacts, and the improvement of the connectivity among patches or populations may remediate the effects of habitat isolation. 
Dispersal studies have often examined a single dispersal stage (emigration or settlement of juveniles or adults). Studies based on a single stage may lead to unreliable conclusions because different conditions may influence dispersal at each stage and/or the same conditions may exert different effects on dispersal at different stages (Ims \& Hjermann 2001, Bowler \& Benton 2005, Clobert et al. 2009). Thus, studies that consider multiple behavioural stages may provide a better understanding of the dispersal process (Bowler \& Benton 2005).

Dispersal has been shown to be a well documented density-dependent process in insects, but there is no clear picture on how population density influences dispersal in vertebrates (Matthysen 2005). Positive density-dependent emigration may arise as a consequence of increased competition (Matthysen 2005), whereas the inhibition of immigration by resident conspecifics may lead to negative density-dependent dispersal (Lambin et al. 2001, Griesser et al. 2008). Alternatively, positive density-dependent immigration may arise if dispersers use the presence or abundance of conspecifics as an index of habitat quality when deciding to settle (i.e. "the conspecific attraction hypothesis"; Smith \& Peacock 1990).

The middle spotted woodpecker (Dendrocopos medius) is a resident bird associated with old deciduous forests of the western Palaearctic that has been shown to be sensitive to habitat loss, fragmentation and degradation (Pettersson 1985, Kossenko \& Kaygorodova 2001, Robles et al. 2007a, 2008, Ciudad et al. 2009). In this paper we examined dispersal of juvenile and adult middle spotted woodpeckers in fragmented habitats from NW Spain (Cantabrian Mountains) and W Russia (Nerussa-Desna woodland) by assessing the effects of habitat patch size (associated with habitat loss and subdivision), habitat isolation (measured as habitat patch connectivity and the characteristics of the matrix surrounding the patches), habitat degradation (measured as the intrinsic habitat patch quality) and patch population density at several behavioural stages. First, we examined the propensity to leave the natal patch and the settlement of juvenile Cantabrian birds. We expected juvenile woodpeckers to be more prone to leave low quality and high density patches to escape adverse conditions (i.e. limited resources and high competition). Besides, juveniles born in small habitat patches are expected to exhibit philopatry because of the incremented emigration 
cost, whereas the influence of isolation is more difficult to predict and will depend on the extinction risk of the remaining habitat patches and on the mortality rate during migration. On the other hand, we expected that juveniles are more likely to settle in high quality, low density, large and well-connected patches, which are more likely to be found by dispersers and may provide a good vacant habitat where to settle in. However, juveniles may prefer to stay in high density natal patches and to settle in high density patches if the abundance of conspecifics is used by young birds as an index of habitat quality (the conspecific attraction hypothesis). Then, we examined breeding dispersal in both study areas. We expected that adult woodpeckers, which rarely leave the breeding patch, are more prone to leave their breeding territory within high quality, low density and large patches, as breeder will be more likely to find a vacant in a good breeding territory by dispersing within these patches. Because habitat patches from Nerussa-Desna woodland hold substantially higher woodpecker densities than Cantabrian patches, we expected that different factors influence breeding dispersal in both populations. Also, we expected a stronger influence of habitat quality, population density, patch size and connectivity on low competitive juveniles, which are probably more prone to escape adverse conditions by dispersal than territorial adults. Not only emigration and immigration, but also dispersal distances were assessed because all these parameters (emigration, immigration and dispersal distance) may be under selection (Bowler \& Benton 2005) and may be affected by different ecological and evolutionary pressures (e.g. Pasinelli \& Walters 2002, Pasinelli et al. 2004).

\section{METHODS}

\subsection{Study areas}

This study was conducted in the Cantabrian Mountains (NW Spain, $42^{\circ} 44^{\prime} \mathrm{N}, 5^{\circ} 1^{\prime}$ W, 900-1250 $\mathrm{m}$ a.s.I.) and the Nerussa-Desna woodland (W Russia, $52^{\circ} 32^{\prime} \mathrm{N}, 34^{\circ} 05^{\prime} \mathrm{E}$, 130-270 $\mathrm{m}$ a.s.l.; Fig. 1). The same woodpecker subspecies (D. m. medius) resides in both areas (Pasinelli 2003). 
The Cantabrian population of middle spotted woodpecker is located at the southwestern edge of its distribution range (Robles et al. 2007a; Fig. 1). This study area $\left(\sim 750 \mathrm{~km}^{2}\right)$ comprises interspersed patches of forest, pastures, scrublands, cereal croplands, urban and rocky areas. Potential breeding habitats for this woodpecker are old-growth deciduous oak forests mainly dominated by Quercus pyrenaica (Robles \& Olea 2003, Robles et al. 2007a). Heavily-disturbed young oak patches and other forested habitats (Pinus pinaster, P. sylvestris, Fagus sylvatica, Populus sp., Salix sp., Fraxinus sp., Q. rotundifolia) are avoided (Onrubia et al. 2004, Robles et al. 2007a). Suitable breeding habitat patches (i.e. old oak forests patches), which hold substantially higher density of large oaks ( $\geq 37 \mathrm{~cm} \mathrm{DBH}$ ) than young oak forest patches (Robles et al. 2007a), cover $\sim 4 \%$ of the area.

The Nerussa-Desna woodland study area $\left(\sim 450 \mathrm{~km}^{2}\right)$ is located at the north-eastern part of the distribution range of middle spotted woodpeckers (Fig. 1). This area is composed by a mosaic of patches of forests, swamps, pastures, cereal croplands and rural areas. Potential breeding habitats for this woodpecker are old-growth oak and oak-ash forests mainly dominated by $Q$. robur and, to a lesser extent, by Fraxinus excelsior (Kossenko \& Kaygorodova 2001, 2007). Heavily-disturbed young oak patches and other forested habitats without oaks (Betula sp., Pinus sylvestris, Alnus glutinosa, Populus tremula, Picea abies, F. excelsior, Tilia cordata) are usually not used for breeding (Kossenko \& Kaygorodova 2001, 2007). However, breeding woodpeckers occasionally use forests without oaks that adjoin old oak forests. Suitable breeding habitat patches (i.e. old oak forest patches; "patches" hereafter) cover $~ 5 \%$ of the area. 


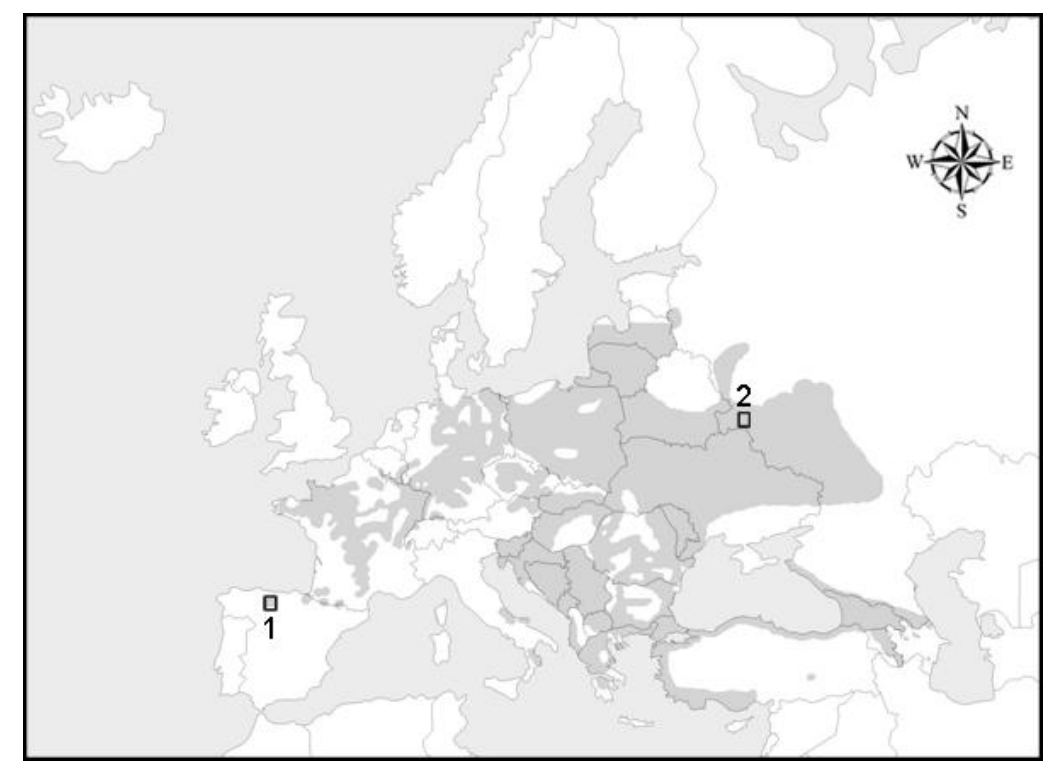

Fig. 1. Distribution range of the middle spotted woodpecker in the Western Palaearctic. The squares show the situation of the Cantabrian (1) and Nerussa-Desna (2) populations.

\subsection{Field methods}

Data on woodpecker dispersal were collected from 2001 to 2010 in the Cantabrian population and from 1997 to 2006 in the Nerussa-Desna woodland. We exhaustively searched for woodpecker nests during nest building-incubation (April-early June) (Kossenko 2003, Robles et al. 2007b, 2008). Most birds were individually colourbanded as nestlings 20-23 days after hatching in the Cantabrian ( $n=172$ nestlings from 18 habitat patches; 2001-2005, 2007 and 2009) and Nerussa-Desna ( $n=415$ nestlings from 9 patches, 1997-2002) populations (Kossenko 2003, Kossenko \& Kaygorodova 2007, Robles et al. 2007b, 2008). Additionally, some adults were captured ( $n=12$ and 65 in the Cantabrian and the Nerussa-Desna populations, respectively) with mist-nets situated in front of the breeding cavities. Blood samples were extracted from the brachial vein of Cantabrian birds for molecular sexing (Robles et al. 2007b). Because sex determination of nestlings resighted as adults in the field (based on differences in the size and the brightness of the red crown patch; see Pasinelli 2003) did not differ from molecular methods, we reasonably assumed that birds were accurately sexed in the Nerussa-Desna woodland, where molecular sexing was not performed and birds were sexed in the field by experienced observers. 
During spring-early summer of each year, we intensively inspected all habitat patches (i.e. old oak forest patches potentially suitable for breeding) within the study areas to locate banded individuals. Habitat patches were monitored 2-6 times ( 20 ha/hour in each visit) from the period of pair formation in February-mid March until the beginning of egg-laying in early May (Kossenko 2003, Robles et al. 2008). Even if all birds within a patch could be observed in the first visit, we performed at least 2-3 visits to see whether new birds colonized the patches later in the pre-breeding season. Detection probability of woodpeckers in a single visit to the habitat patches was 0.962 , and nearly 1.00 when two visits were performed (Robles 2004). If birds could not be properly observed in the first visits, we increased the number of visits to confirm the colour ring combination of banded woodpeckers. Occasionally, observations at the nests in May-early July were also done to confirm the colour ring combinations. In each visit, kweek and rattle calls were played back to find the territory owners as quickly as possible. Once the presence of woodpeckers was detected we stopped using the playback technique to avoid attracting birds from nearby territories (Kossenko \& Kaygorodova 2001, Robles et al. 2008). Woodpeckers were followed and signs of activity (visual and auditive) and intra-specific interactions were recorded (Robles \& Olea 2003, Kossenko 2003, Robles et al. 2008). By using these methods, we could accurately estimate the number of territories in the habitat patches (Kosiński et al. 2004, Robles et al. 2008).

\subsection{Natal dispersal distance and emigration from the natal patch}

Natal dispersal was defined as the movement performed by an individual from its birthplace to the site of first potential breeding (Greenwood 1980). Dispersal distances were measured from the natal nest either to the first breeding nest or to the centroid of the breeding territory if the breeding nest was unknown. Middle spotted woodpeckers reach reproductive competence in year following fledging (Pasinelli 2003). Overall, 60 banded nestlings were later observed in the adulthood. Most juveniles $(n=54)$ were resighted the following spring after fledging, five birds were missed in their first reproductive year but resighted in their second one, and the remaining juvenile was resighted four years after fledging. Birds were probably missed 
or the colour ring combinations could not be determined due to inadequate observation conditions (i.e. high vegetation cover, low light conditions and/or elusive behaviour of the birds), although we cannot discard that some birds stayed in other areas before being resighted. Results did not change qualitatively when temporally missing birds were excluded.

We tested the influence of several environmental factors on natal dispersal (dispersal distance and emigration propensity from the natal patch) for the Cantabrian population exclusively, as dispersal was recorded for only 17 juveniles born in four patches in the Nerussa-Desna woodland. Linear mixed effects models (LME) were used to examine natal dispersal distance. We also examined the propensity to disperse out of the natal patches, as inter-patch dispersal may favour the persistence of metapopulations (Hanski \& Gilpin 1997) and rescue declining or sink populations from extinction (Brown \& Kodric-Brown 1977, Watkinson \& Sutherland 1995). The propensity to disperse out of the natal patches was analysed by generalized linear mixed models (GLMM) with binomial error distributions and logistic link functions (inter-patch disperser 1, non-disperser 0). Because most juveniles dispersed out of the natal territory (41 of 43 cases), no analyses on the propensity to disperse out of the natal territory were done. We assumed that birds could assess the characteristics of the natal patch and not only those of the natal territory, which is reasonable because juveniles of many organisms, including the middle spotted woodpecker, perform exploratory movements out of the natal territory before dispersal (Haughland \& Larsen 2004, Selonen \& Hanski 2006, authors' unpublished data). Consequently, several habitat patch-related variables were fitted as fixed terms in both dispersal distance and emigration analyses: patch size, patch connectivity, patch quality and population density (number of territories/10 ha) in the natal patch (Fig. 2a-c). Natal patch size was calculated with ArcGIS 9.2 (ESRI, <www.esri.com>) from aerial photographs verified in the field (Robles et al. 2008). Patch connectivity was calculated by using the "proximity index" in FRAGSTATS version 3.3 (McGarigal et al. 2002) as follows:

$$
\operatorname{PROX}=\sum_{i}\left(s_{i} / d_{i}^{2}\right)
$$


where $s_{i}$ is the size of the patch $i$, and $d_{i}$ is the distance from the focal patch to the patch i (including all habitat patches occupied by woodpeckers within a 5215 meterswide zone around the natal patch, i.e. the median dispersal distance for inter-patch dispersers). Increasing values indicate lower degree of isolation. We obtained qualitatively similar results when other buffers were used for calculation of the proximity index. We also calculated the proportion of deciduous forests (young oak and riverine forests) within the $5215 \mathrm{~m}$ buffer area around the natal patch to assess the influence of the matrix on natal dispersal, as young oak and riverine forests, even if unsuitable for breeding, may mitigate dispersal costs associated with fragmentation by providing food and coverage to juvenile woodpeckers during inter-patch movements (Robles et al. 2007b, Ciudad et al. 2009, Chapter III). The density of large oaks ( $\geq 37 \mathrm{~cm}$ $\mathrm{DBH}$, diameter at $1.3 \mathrm{~m}$ above ground) was taken as a measure of the intrinsic habitat patch quality, as it provides foraging opportunities to postfledging juveniles and breeding adults and is also correlated to the density of potential nesting trees (Robles et al. 2007a, Ciudad et al. 2009, Chapter III). The abundance of large oaks has been shown to influence the probability of occupancy (Robles et al. 2007a, Chapter IV) and home range sizes in the middle spotted woodpecker (Pasinelli 2000). Large oak density was estimated by establishing a network of 0.04 ha circular plots $\geq 100 \mathrm{~m}$ apart (Robles et al. 2007a, 2008) in the natal patches. Plots were always regularly spaced, but the number of plots established in each patch varied with the surface and habitat heterogeneity of the patches (Ciudad et al. 2009). Sex was also fitted as a fixed term. Natal patch identity $(n=15)$, and brood identity $(n=33)$ nested within patch identity, were included as random terms to control for multiple observations within the same patches and broods in the analyses of dispersal distances, but brood identity was not included in the analyses of emigration to allow model convergence. Consequently, only one randomly-chosen sibling per brood was included in emigration analyses. 

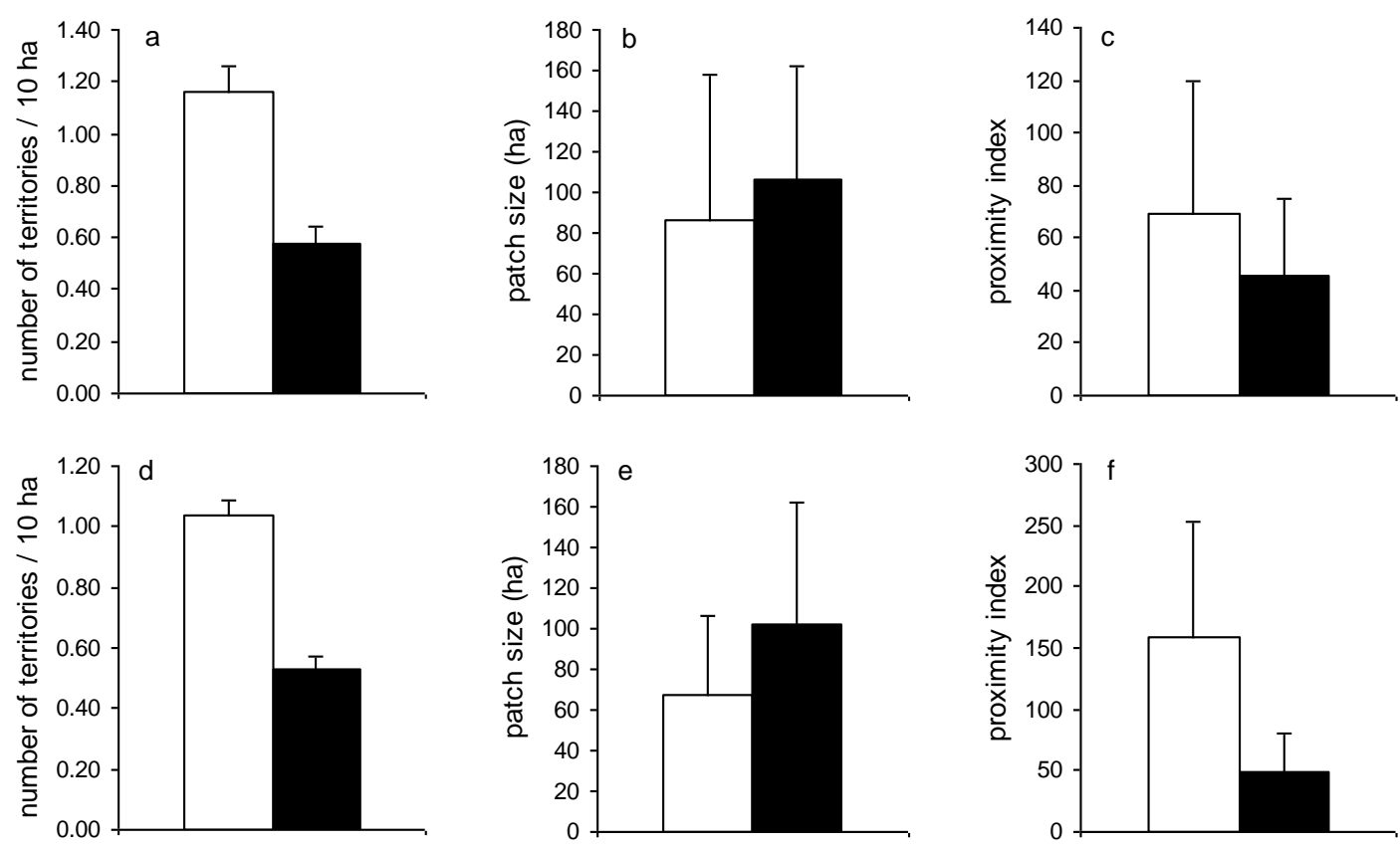

Fig. 2. Mean $(+\mathrm{SE})$ population density (number of territories/10 ha), size (in ha) and connectivity (proximity index) of the patches where natal (a-c) and breeding (d-f) dispersal events were observed in the Nerussa-Desna (white bars) and Cantabrian (black bars) study areas. In Nerussa-Desna, natal and breeding dispersal were estimated from 4 and 8 patches, respectively. In the Cantabrian area, natal and breeding dispersal were estimated from 15 and 14 patches.

\subsection{Settlement of inter-patch juvenile dispersers}

Binomial GLMMs were used to assess the influence of several environmental factors on the settlement of juveniles that left the natal patch in the Cantabrian population. No analyses were performed for the Nerussa-Desna population because of small sample sizes (five settlement patches for females and two for males). The size, connectivity, quality and population density of every settlement patch, in addition to the proportion of deciduous forest surrounding the settlement patch, were compared to those characteristics of the five closest patches where juveniles did not settle. Besides, the dispersal distance was fitted as a fixed term. We found similar results when the characteristics of the settlement patch were compared to those of the one closest and the three closest patches where juveniles did not settle. Because juvenile woodpeckers visit the patches around the settlement patch in different directions during the early postfledging period (Ciudad et al. 2009, Chapter III, authors' unpublished data), we reasonably assume that the patches surrounding the settlement patch were available to woodpeckers. Population density was measured in the natal 
year, as juvenile woodpeckers search for a future breeding site and can reach the settlement patch in the early postfledging period (Ciudad et al. 2009, Chapter III). We found similar results when we used population density in year when settlement was confirmed. The identity of the settlement area (i.e. the settlement patch and the nearby patches) was included as a random term to control for multiple observations within the same areas. The settlement of females ( $n=12$ settlement patches) and males $(n=9)$ was analyzed separately. If several individuals settled in the same patch, the settlement of one randomly-chosen male and female was considered in analyses (i.e. each patch was associated with the settlement of maximum one male and one female).

\subsection{Breeding dispersal distance and emigration from the breeding territory}

Breeding dispersal was defined as the movement performed by an individual between consecutive breeding sites (Greenwood \& Harvey 1982). Dispersal distances were measured between subsequent breeding nests or between centroids of breeding territories. We recorded 131 breeding dispersal events (72 and 59 in Nerussa-Desna and Cantabrian populations, respectively). Middle spotted woodpeckers raise one brood per year (Pasinelli 2003). Most adults were resighted the following spring ( $n=$ 124), four were missed the subsequent breeding season but resighted the following one, two were missed by two years, and the remaining adult by four years. Birds were probably missed or colour ring combinations could not be determined due to inadequate observation conditions. Results did not change qualitatively when temporally missing birds were excluded.

The influence of several factors on breeding dispersal distance (LME) and emigration propensity from the breeding territory (binomial GLMM) was examined separately for each study area, as different sets of predictors were available for Nerussa-Desna and Cantabrian populations. Size, connectivity and population density of the origin patch, in addition to individual sex, were fitted as fixed terms in analyses of both populations. We assume that birds could assess the characteristics of the breeding patch and not only those of the breeding territory. Indeed, all three radiotracked adults in the Cantabrian Mountains performed extraterritorial 
movements within the breeding patch (authors' unpublished data). In the NerussaDesna woodland, patch size was calculated from forestry maps verified in the field (Kossenko \& Kaygorodova 2001, 2007), whereas patch connectivity (i.e. the proximity index) was calculated within a 3560 meters-wide zone around the breeding patch (i.e. the median dispersal distance for inter-patch dispersers in Nerussa-Desna). Also, habitat patch quality and the proportion of deciduous forest surrounding the breeding patch were included as fixed terms in analyses of the Cantabrian population. Patch identity ( $n=14$ and 8 patches in Cantabrian and Nerussa-Desna populations, respectively) and individual identity ( $\mathrm{n}=30$ and 32 individuals, respectively) were included as random terms to control for multiple observations within the same patches and individuals (median number of observations per individual $=2$, range $=1$ 6). No analyses on emigration propensity from the breeding patch were done because of the small number of inter-patch dispersers in both Cantabrian (five cases) and Nerussa-Desna (two) populations.

Then, we assessed potential differences in the size, connectivity and population density of the patches used for analyses of breeding dispersal between Nerussa-Desna and Cantabrian areas, which can help to understand why different factors influenced breeding dispersal in both areas. Differences in the connectivity and the size of the patches were analysed by generalized linear models (GLM) with study area as predictor. Differences in patch population density between areas were analysed by LME with study area fitted as a fixed term and patch identity as a random term to control for multiple observations of density within the same patches.

\subsection{Model selection and statistical inferences}

We used an information-theoretic approach to assess which variables and models best explained the data (Burnham \& Anderson 2002). Unlike the conventional null hypothesis testing approach, the information-theoretic approach, which recognises the uncertainly associated with biological data and does not rely on arbitrary significance levels, allows calculating model-averaged parameter estimates and standard errors by considering non-exclusive candidate models. This is particularly relevant when several factors may influence the dependent variable (Stephens et al. 
2005, Garamzsegi et al. 2009). We run a set of models for each analysis previously indicated except for the comparison of patch size, connectivity and population density between Nerussa-Desna and Cantabrian areas, as only one predictor (study area) was included in these analyses. Because the information available about the system is scarce, we could not apply specific models based on previous knowledge (Stephens et al. 2005). Thus, every set of models contained all the possible combinations of the specific variables. Model selection followed Akaike's Information Criterion corrected for small sample sizes (AICC) and Akaike model weights (Burnham \& Anderson 2002). Akaike model weights quantify the support of every model by the data, being 1 the sum of all weights. Models with $\triangle \mathrm{AICC}<2$ compared to the model with smallest AICC (i.e. the "best model") are considered to be well supported by the data (Burnham \& Anderson 2002). To assess model fit of the high ranked models, the deviance $R^{2}$ analog was calculated as

$$
R^{2}=1-\left(\text { deviance }_{\text {model }}\right)^{2} /\left(\text { deviance }_{\text {maximum }}\right)^{2},
$$

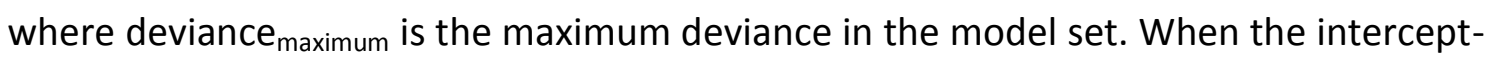
only model was not included within the high ranked models (i.e. $\Delta \mathrm{AICC}>2$ ), modelaveraged parameter estimates and standard errors for each variable were calculated across the set of all candidate models that contained all the possible combinations of the specific variables. We also calculated the relative importance of each variable by summing the weights over all the models containing such variable (Burnham \& Anderson 2002).

Most predictor variables for each analysis were weakly correlated (i.e. $r_{s} \leq|0.55|$ ), showing that multicollinearity was not a problem. The exception was the correlation between patch size and connectivity in the analysis of breeding dispersal propensity $\left(r_{s}\right.$ $=0.72$ and -0.64 in Nerussa-Desna and Cantabrian populations, respectively). Before analyses, continuous variables were standardized to have zero mean and variance of one. Because of the small sample sizes, effects of year, interactions between predictors, and non-linear relationships (e.g. by adding quadratic or cubic terms) were not tested in any analyses. All statistical analyses were performed in R 2.10.1 ( $R$ Development Core Team 2009). 


\section{RESULTS}

\subsection{Natal dispersal}

Median natal dispersal distance was $2393 \mathrm{~m}$ (quartiles $=473$ and 3481, $\mathrm{n}=17$ ) and $3500 \mathrm{~m}$ (quartiles $=1056$ and 7908, $\mathrm{n}=43$ ) in Nerussa-Desna and Cantabrian populations, respectively (Fig. 3a). Most juveniles emigrated out of the natal territory (94.1\% and $95.3 \%$ in Nerussa-Desna and Cantabrian populations, respectively), often out of the natal patch (41.2\% and $74.4 \%)$. Median dispersal distance for inter-patch dispersers was $3560 \mathrm{~m}$ (quartiles $=2848$ and 10410, $\mathrm{n}=7$ ) and $5215 \mathrm{~m}$ (quartiles = 1816 and 8449, $n=32$ ) in Nerussa-Desna and Cantabrian populations, respectively. Median dispersal distance for juveniles that did not leave the natal patch was $667 \mathrm{~m}$ (quartiles $=399$ and $1840, \mathrm{n}=10$ ) and $400 \mathrm{~m}$ (quartiles $=280$ and $644, \mathrm{n}=11$ ), respectively.
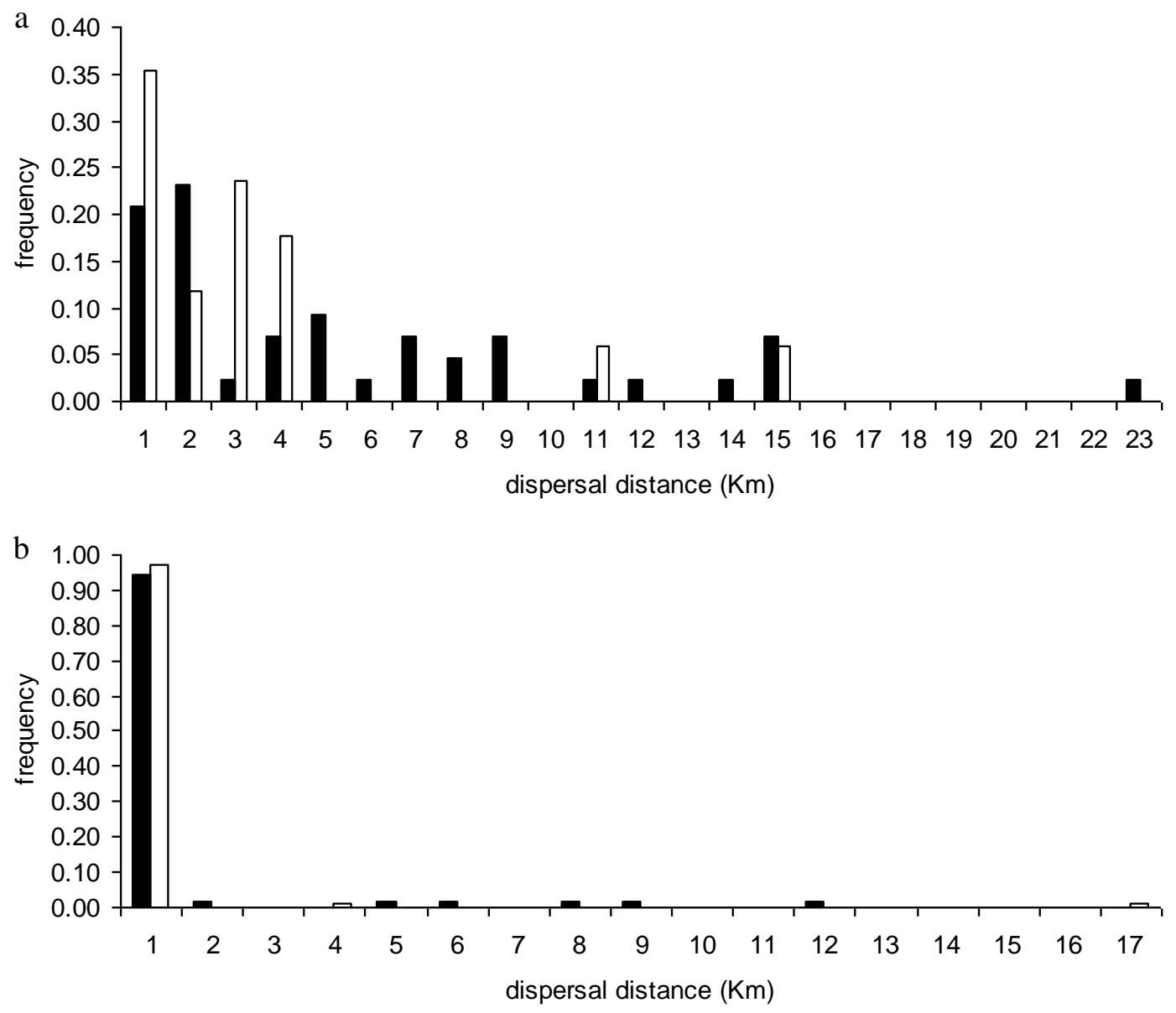

Fig. 3. Frequency of observed natal (a) and breeding (b) dispersal distances (in $\mathrm{Km}$ ) of middle spotted woodpeckers monitored at Nerussa-Desna (white bars, $n=17$ and 72 movements for natal and breeding dispersal, respectively) and Cantabrian (black bars, $n=43$ and 59) study areas. 
Emigration from the natal patch, dispersal distance and settlement in the

\section{Cantabrian population}

Model selection of analyses of emigration propensity from the natal patch yielded several high ranked models containing different combinations of habitat quality, patch size and population density as predictors (Table 1, see Appendix 1 for the full model set). Habitat quality had a high relative importance value and was included in the three highest ranked models (Tables 1 and 2). Juveniles born in high quality habitats had low probability of emigration out of the natal patch (Table 2, Fig. 4). Patch size and population density had lower relative importance values than habitat quality and considerably smaller model-averaged parameter estimates compared to their associated standard errors (Tables 2), indicating little influence of both variables on emigration. Patch connectivity, sex and the proportion of deciduous forest within the matrix were not included in the high ranked models, had low relative importance values and small model-averaged parameter estimates compared to their associated standard errors (Tables 1 and 2), indicating little influence of these variables on emigration.

Table 1. Model selection of analyses examining emigration propensity out of the natal patch ( $n=24$ juvenile dispersers vs 9 philopatric juveniles) in the Cantabrian population by binomial GLMMs. Patch identity $(n=15)$ was fitted as a random term. Models with $\Delta A I C c<2$ to the best model within the set of candidate models are indicated. Models are ranked according to their Akaike weight (Weight). $K$ : number of parameters, AICC: AIC corrected for small sample size, $\triangle \mathrm{AICC}$ : difference in AICC to the best model.

\begin{tabular}{lcccccc}
\hline Selected models & Deviance & $K$ & AICc & $\Delta$ AICc & Weight & $R^{2}$ \\
\hline Habitat quality, patch size & 25.93 & 4 & 35.02 & 0.00 & 0.157 & 0.546 \\
Habitat quality, population density & 26.99 & 4 & 36.08 & 1.06 & 0.093 & 0.508 \\
Habitat quality, patch size, population density & 24.97 & 5 & 36.64 & 1.62 & 0.070 & 0.579 \\
\hline
\end{tabular}


Table 2. Model-averaged parameter estimates and their associated standard errors (relative importance values in brackets) for variables included in the analyses of emigration propensity from the natal patch in the Cantabrian population.

\begin{tabular}{lr}
\hline Variable & \multicolumn{1}{c}{ Estimate \pm SE } \\
\hline Habitat quality & $-1.080 \pm 0.853(0.78)$ \\
Patch size & $-0.821 \pm 1.080(0.64)$ \\
Population density & $0.500 \pm 0.741(0.45)$ \\
Patch connectivity & $-0.118 \pm 0.278(0.30)$ \\
Sex & $0.089 \pm 0.307(0.23)$ \\
Deciduous forest & $-0.054 \pm 0.171(0.23)$ \\
\hline
\end{tabular}

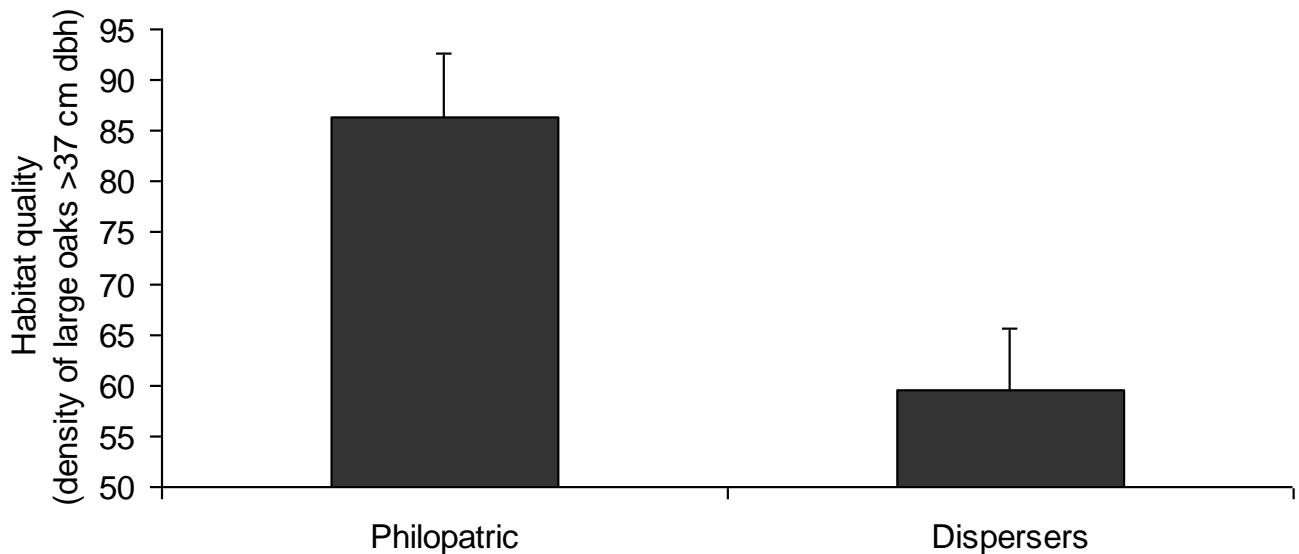

Fig. 4. Mean (+SE) habitat quality (number of large oaks $>37 \mathrm{~cm} \mathrm{DBH/ha)} \mathrm{for} \mathrm{natal} \mathrm{patches} \mathrm{occupied} \mathrm{by}$ juveniles that emigrated out of the natal patch ( $n=9$ juveniles from 5 patches) and for patches occupied by philopatric juveniles ( $n=24$ juveniles from 13 patches) included in analyses of emigration from the natal patch in the Cantabrian population.

In analyses of natal dispersal distance, the intercept-only model was one of the highest ranked models $(\triangle \mathrm{AICC}=1.082)$, indicating that predictors had low influence. Similarly, the intercept-only model was one of the highest ranked models $(\triangle \mathrm{AICc}=$ 1.793) when only inter-patch dispersers were included in analyses. 
Model selection of male settlement analyses yielded several high ranked models containing different combinations of all the predictors except dispersal distance and the proportion of deciduous forest within the matrix (Table 3, see Appendix 2 for the full model set). Patch size, population density and habitat quality had high relative importance values (Table 4). Males preferred high density patches to settle (Table 4, Fig. 5a). Patch size and habitat quality had slightly smaller parameter estimates than their associate standard errors (Table 4), suggesting a limited influence of both variables. If anything, males preferred to settle in large and high quality patches, as indicated by the positive parameter estimates for patch size and habitat quality (Table 4). The relative importance values of dispersal distance, patch connectivity and the proportion of deciduous forest within the matrix were low $(<0.45)$, and their modelaveraged estimates were considerably smaller than the associated standard errors (Table 4), further indicating low influence of these variables.

Table 3. Model selection of analyses examining male ( $n=9$ settlement patches vs 45 nearby patches) and female ( $n=12$ settlement patches vs 60 nearby patches) settlement in the Cantabrian population by binomial GLMMs. The identity of the settlement area (every settlement patch and the closest five patches) was fitted as a random term. The rest as in Table 1.

\begin{tabular}{|c|c|c|c|c|c|c|c|}
\hline Sex & Selected models & Deviance & $K$ & AICc & $\triangle \mathrm{AICC}$ & Weight & $R^{2}$ \\
\hline \multirow[t]{9}{*}{ Males } & Population density, Patch size & 38.33 & 4 & 47.15 & 0.00 & 0.086 & 0.380 \\
\hline & Population density, Habitat quality, Patch connectivity, Patch size & 33.94 & 6 & 47.73 & 0.58 & 0.064 & 0.514 \\
\hline & Population density, Patch connectivity, Patch size & 36.51 & 5 & 47.76 & 0.61 & 0.063 & 0.437 \\
\hline & Habitat quality, Patch size & 39.12 & 4 & 47.93 & 0.78 & 0.058 & 0.354 \\
\hline & Population density, Habitat quality, Patch size & 36.80 & 5 & 48.05 & 0.89 & 0.055 & 0.428 \\
\hline & Habitat quality & 41.76 & 3 & 48.24 & 1.09 & 0.050 & 0.263 \\
\hline & Habitat quality, Patch connectivity, Patch size & 37.16 & 5 & 48.41 & 1.26 & 0.046 & 0.417 \\
\hline & Population density, Habitat quality & 39.63 & 4 & 48.45 & 1.30 & 0.045 & 0.337 \\
\hline & Poulation density & 42.21 & 3 & 48.69 & 1.54 & 0.040 & 0.248 \\
\hline \multirow[t]{5}{*}{ Females } & Population density, Habitat quality & 54.54 & 4 & 63.13 & 0.00 & 0.127 & 0.293 \\
\hline & Population density, Habitat quality, Patch connectivity, Patch size & 50.98 & 6 & 64.27 & 1.14 & 0.072 & 0.383 \\
\hline & Population density & 58.02 & 3 & 64.37 & 1.24 & 0.069 & 0.200 \\
\hline & Population density, Patch size & 56.10 & 4 & 64.70 & 1.57 & 0.058 & 0.252 \\
\hline & Population density, Habitat quality, Patch size & 53.83 & 5 & 64.74 & 1.61 & 0.057 & 0.312 \\
\hline
\end{tabular}


Table 4. Model-averaged parameter estimates and their associated standard errors (relative importance values in brackets) for variables included in analyses of male and female settlement in the Cantabrian population.

\begin{tabular}{lcc}
\hline Variable & Males & Females \\
\hline Population density & $0.546 \pm 0.528(0.66)$ & $0.599 \pm 0.368(0.85)$ \\
Habitat quality & $0.493 \pm 0.544(0.59)$ & $0.421 \pm 0.421(0.64)$ \\
Patch size & $0.616 \pm 0.694(0.67)$ & $0.240 \pm 0.382(0.43)$ \\
Patch connectivity & $-0.278 \pm 0.577(0.38)$ & $-0.183 \pm 0.380(0.35)$ \\
Deciduous forest & $-0.017 \pm 0.149(0.24)$ & $-0.008 \pm 0.102(0.24)$ \\
Dispersal distance & $0.004 \pm 0.116(0.24)$ & $0.018 \pm 0.107(0.24)$ \\
\hline
\end{tabular}

Similar to males, model selection of female settlement analyses yielded several high ranked models containing combinations of all the predictors except dispersal distance and the proportion of deciduous forest within the matrix (Table 3, see Appendix 3 for the full model set). Population density had the highest relative importance value $(0.85)$ and was included in all the highest ranked models. Females preferred to settle in high density patches (Table 4, Fig. 5b). The high relative importance value of habitat quality and its positive model-averaged estimate also show that females preferred to settle in high quality patches (Table 4, Fig. 5c). The relative importance values of dispersal distance, the proportion of deciduous forest within the matrix, patch size and connectivity were low $(<0.5)$, and their small model-averaged estimates compared to the standard errors (Table 4) indicate low influence of these variables. 

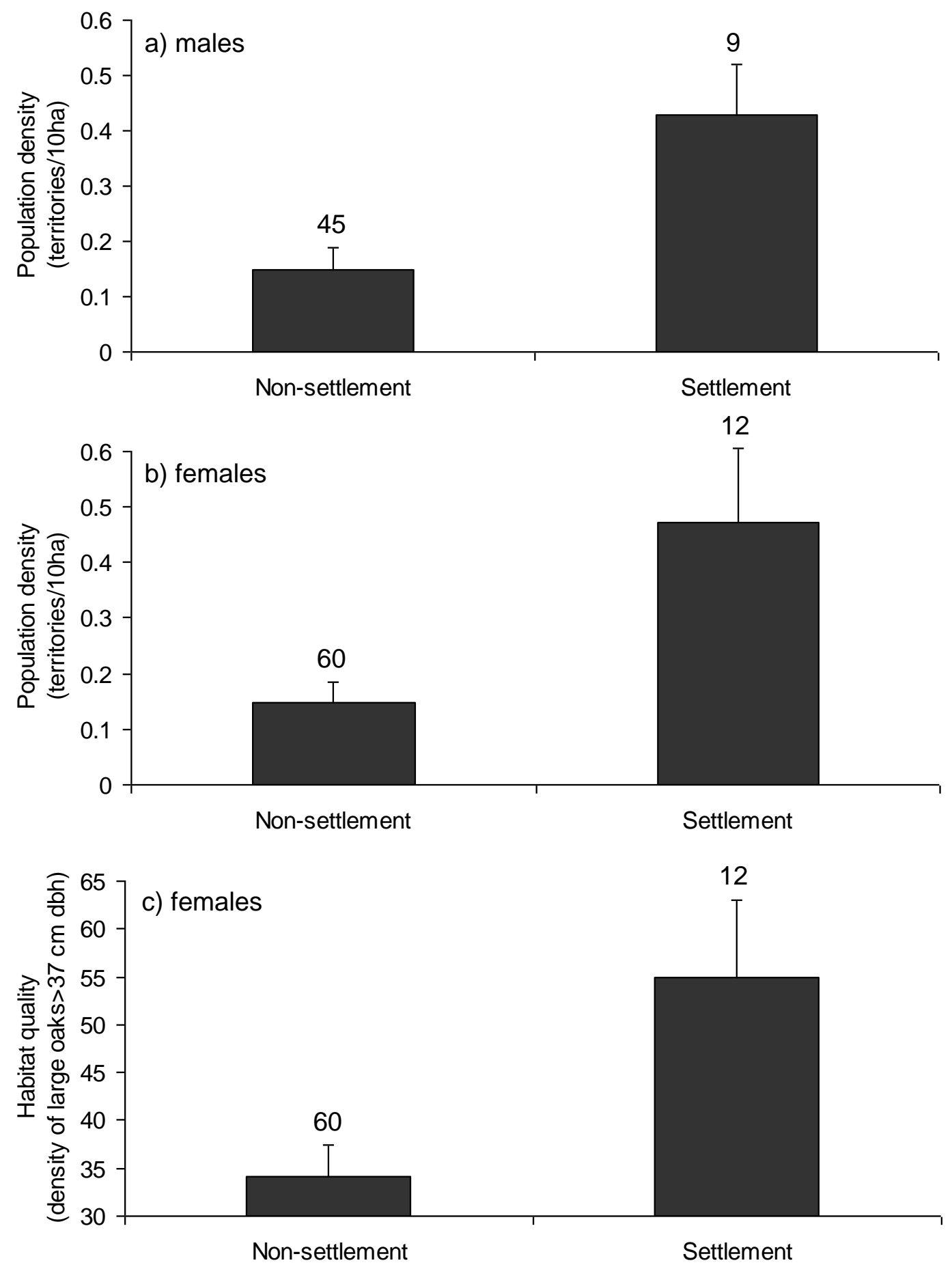

Fig. 5. Mean ( $+\mathrm{SE}$ ) population density (number of territories/10 ha) and habitat quality (number of large oaks>37 cm DBH/ha) of settlement and non-settlement patches for juvenile males (a) and females (b and c). Numbers above bars are the number of patches. 


\subsection{Breeding dispersal}

Median breeding dispersal distance was $181 \mathrm{~m}$ (quartiles $=78$ and 335, $\mathrm{n}=72$ ) and $114 \mathrm{~m}$ (quartiles $=67$ and 320, $\mathrm{n}=59$ ) in Nerussa-Desna and Cantabrian populations, respectively (Fig. 3b). Some adults left the breeding territory $(30.6 \%$ and $25.0 \%$ in Nerussa-Desna and Cantabrian populations, respectively), but emigration out of the breeding patch was rather uncommon ( $2.8 \%$ and $8.9 \%$, respectively). Considering only birds that dispersed out of the breeding territory, median dispersal distance was $379 \mathrm{~m}$ (quartiles $=255$ and 567, $\mathrm{n}=22$ ) and $616 \mathrm{~m}$ (quartiles $=353$ and 5644, $\mathrm{n}=14$ ) in Nerussa-Desna and Cantabrian populations, respectively. Median dispersal distance for philopatric woodpeckers was $128 \mathrm{~m}$ (quartiles $=50$ and $233, \mathrm{n}=50$ ) and $79 \mathrm{~m}$ (quartiles $=54$ and $137, n=45$ ), respectively.

Emigration from the breeding territory and dispersal distance in the Cantabrian population

In analyses of emigration propensity from the breeding territory, the intercept-only model was the second best model with $\triangle \mathrm{AICc}=0.126$, indicating that predictors had low influence.

In analyses of dispersal distance, the intercept-only model was one of the highest ranked models $(\triangle \mathrm{AICC}=1.136)$, indicating that predictors had low influence. Analyses of dispersal distance considering only the displacements of dispersers were not possible because of the small number of dispersal events $(n=14)$.

Emigration from the breeding territory and dispersal distance in the Nerussa-Desna population

The best model explaining emigration propensity from the breeding territory included patch size (Table 5, see Appendix 4 for the full model set). The high relative importance value of patch size and its positive model-averaged parameter estimate show that woodpeckers in large patches were more prone to emigrate (Table 6, Fig. 6). Patch connectivity, population density and sex had low relative importance values and 
small model-averaged parameter estimates compared to their standard errors (Table $6)$, suggesting low influence of these variables.

Table 5. Model selection of analyses examining emigration propensity from the breeding territory ( $n=22$ dispersal events vs 50 philopatric events) in the Nerussa-Desna population by binomial GLMMs. Patch identity $(n=8)$ and individual identity $(n=32)$ were fitted as random terms. The rest as in table 1.

\begin{tabular}{lcccccc}
\hline Selected models & Deviance & $K$ & AICc & $\Delta$ AICc & Weight & $R^{2}$ \\
\hline Patch size & 81.38 & 4 & 89.98 & 0.00 & 0.290 & 0.112 \\
Patch size, Patch connectivity & 81.02 & 5 & 91.93 & 1.95 & 0.110 & 0.120 \\
\hline
\end{tabular}

Table 6. Model-averaged parameter estimates and their associated standard errors (relative importance values in brackets) for variables included in the analyses of emigration propensity from the breeding territory in the Nerussa-Desna population.

\begin{tabular}{lc}
\hline Variables & Estimate \pm SE \\
\hline Patch size & $0.516 \pm 0.443(0.70)$ \\
Patch connectivity & $0.095 \pm 0.183(0.32)$ \\
Population density & $0.086 \pm 0.181(0.30)$ \\
Sex & $-0.003 \pm 0.137(0.24)$ \\
\hline
\end{tabular}

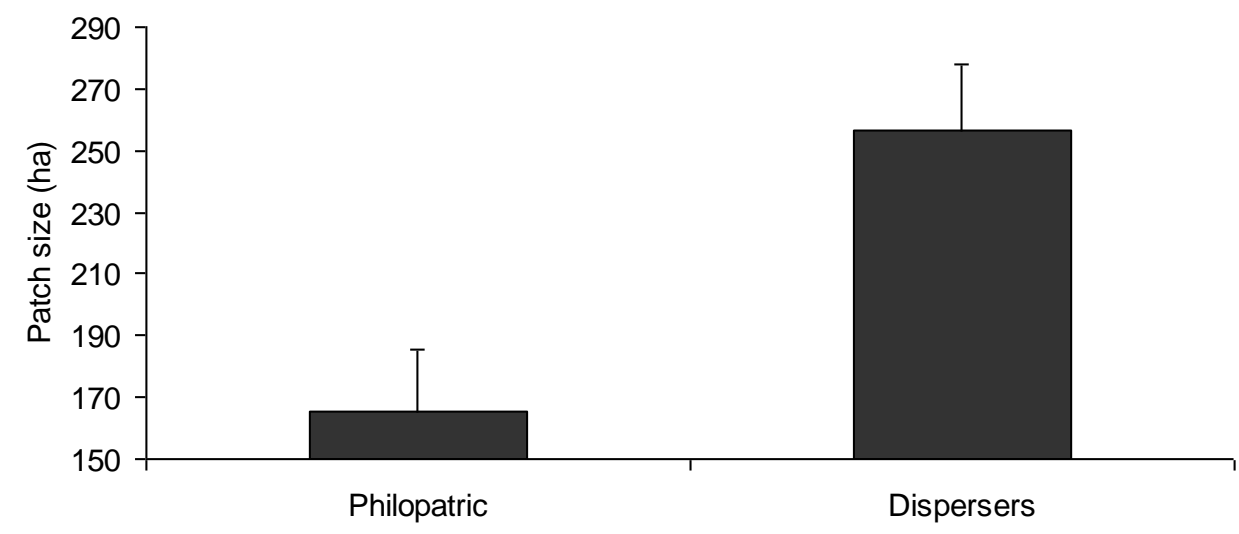

Fig. 6. Mean ( $+S E$ ) patch size (in ha) for adults that emigrated out of the breeding territory ( $n=22$ movements performed by 16 adults from 4 patches) and for philopatric adults ( $n=50$ movements performed by 26 adults from 8 patches) in the Nerussa-Desna population. 
In analyses of dispersal distance, the intercept-only model was one of the highest ranked models $(\triangle \mathrm{AICC}=1.270)$, indicating that predictors had low influence. Analyses of dispersal distance considering only dispersers were not possible because of the small number of patches $(n=4)$ occupied by dispersing adults.

Differences in patch size, connectivity and population density between Cantabrian and Nerussa-Desna study areas

Patches in Nerussa-Desna were better connected (GLM with study area as predictor: parameter estimate $\pm \mathrm{SE}=1.101 \pm 0.490, t=2.247, P=0.036)$ and had higher woodpecker density (LME: parameter estimate $\pm \mathrm{SE}=0.422 \pm 0.141, t=2.990, P$ $=0.007, \mathrm{n}=35$ cases from 14 patches in the Cantabrian area and 28 cases from 8 patches in Nerussa-Desna) than those in Cantabrian Mountains (Fig. 2d and 2f). Differences in the size of the patches between areas were rather small (GLM: parameter estimate $\pm \mathrm{SE}=-0.225 \pm 0.237, t=-0.950, P=0.353$; Fig. 2e).

\section{DISCUSSION}

This study examines the effects of habitat quality, population density, patch size and connectivity on emigration, settlement and dispersal distance of juvenile and adult middle spotted woodpeckers. Habitat patch connectivity and the proportion of deciduous forest within the surrounding matrix had little influence on dispersal parameters. However, patch size, habitat quality and population density had different effects on dispersal at several behavioural stages examined. In juveniles from the Cantabrian population, patch size had little influence on the emigration from the natal patch or the settlement of inter-patch dispersers, but adult woodpeckers in large patches were more likely to leave the breeding territory in Nerussa-Desna. Moreover, juveniles born in higher quality habitats were more likely to remain in the natal patch, whereas female dispersers tended to settle in better quality patches, but habitat quality did not have a strong influence on breeding dispersal. On the other hand, population density had low influence on emigration propensity of juveniles and adults, but young woodpeckers preferred to settle in high density patches. Thus, different 
conditions influenced dispersal at each behavioural stage (emigration or settlement of juveniles or adults) and some conditions had different effects (strong vs limited influence) on different dispersal stages. These results, therefore, highlight the importance of assessing simultaneously the influence of habitat quality, population density, patch size and connectivity on multiple dispersal stages to a better understanding of the dispersal process. In the following sections we discuss separately the effects of patch size, patch connectivity, habitat quality and population density on woodpecker dispersal, with relevant conservation implications.

\subsection{Effects of patch size on natal and breeding dispersal}

Habitat loss has been suggested to promote philopatry by increasing the cost of emigration (Travis \& Dytham 1999). However, our results did not support this hypothesis, as patch size reduction due to habitat loss did not decrease emigration of juveniles (i.e. the main dispersers) from the natal patch, and young woodpeckers frequently left the natal patch. Conversely, in Nerussa-Desna woodland, adult woodpeckers in large patches were more prone to leave the breeding territory, apparently supporting the idea that the reduction in patch sizes limited emigration. However, most adults performed within-patch movements (70 of 72) rather than interpatch displacements between subsequent breeding seasons, so emigration out of the patches was not reduced.

Differences in the influence of patch size on the propensity to leave the breeding territory between Cantabrian and Nerussa-Desna populations may be explained by differences in population densities between these areas. In the high populated breeding patches of the Nerussa-Desna woodland, larger patches may be more likely to hold vacant territories than smaller ones, as larger patches provide more space where to settle in. Thus, emigration by breeders was mainly conditioned by patch size. Conversely, patch size had little influence in the low populated Cantabrian Mountains, perhaps because both small and large patches provide opportunities (vacant territories) for breeding dispersal. Alternatively, the strong influence of patch size in Nerussa-Desna may arise if there is a high variation in habitat quality of breeding territories within large patches but not within small patches, so within-patch dispersal 
may be a more successful strategy in larger patches. Information on habitat quality of territories in patches of Nerussa-Desna is necessary to assess this hypothesis.

\subsection{Effects of patch connectivity on inter-patch dispersal}

Patch connectivity and the proportion of deciduous forest within the surrounding matrix had little influence on dispersal distance, emigration or settlement of juvenile woodpeckers, apparently suggesting that habitat isolation did not disrupt inter-patch mobility. This may arise because the degree of patch isolation in this area may not suffice to alter woodpecker dispersal, or because the forested matrix may mitigate dispersal cost in the Cantabrian area. Nevertheless, given our small sample sizes and the inherent difficulty to measure real connectivity, these results should be taken with caution. Besides, habitat isolation may have a strong influence on dispersal in other middle spotted woodpecker populations subjected to severe patch isolation.

Our results contrast with those of Cooper \& Walters (2002) showing experimentally that a disruption in the connectivity in fragmented habitats led to short natal dispersal distances and low recruitment of females in the cooperatively breeding brown treecreeper (Climacteris picumnus). Between-studies differences may arise because, unlike non-cooperative species, competition for breeding status in social groups may lead to short dispersal distances and low individual interchange between populations of cooperatively breeding species, as experience and previous familiarity with the social group appears to play an important role to gain breeding positions (Yáber \& Rabenold 2002). Consequently, social resistance to immigration can threaten the persistence of populations by reducing gene flow and potential demographic rescue, particularly in fragmented habitats (Yáber \& Rabenold 2002).

Previous studies have shown an increment of natal dispersal distances in large fragmented study areas in comparison to small continuous ones in Eurasian nuthatches (Sitta europaea) and Florida scrub-jays (Aphelocoma coerulenses) (Matthysen et al. 1995, Breininger 1999, Coulon et al. 2010). However, such study approach may lead to confounding results because dispersal distances estimated in small study areas are expected to be shorter than those in larger areas, as more long 
dispersal events are missed out of small plots (Koenig et al. 1996). Our estimations on woodpecker dispersal support this hypothesis. Indeed, a substantial lower proportion of juveniles were resighted as adults in the Nerussa-Desna population (4.1\% of 415 young) compared to the Cantabrian Mountains (25.0\% of 172), probably because more birds dispersed out of the smaller Nerussa-Desna study area (450 vs $750 \mathrm{~km}^{2}$ ). Consequently, the distribution of dispersal distances is probably more biased to short dispersal events in the Nerussa-Desna woodland compared to Cantabrian Mountains (see Fig. 3a), as more inter-patch dispersal events were observed in the latter area (41.2\% vs $74.4 \%)$. Unlike the Nerussa-Desna population, the apparent survival observed in the Cantabrian population suffices to allow its persistence (Robles et al. 2007b), suggesting that, even if some birds could disperse out of the study area, our data provide a good approach to dispersal distance distribution in the Cantabrian Mountains. Future research should compare dispersal distance distributions in large study areas of similar size between fragmented and more continuous habitats to assess whether habitat loss and fragmentation alter dispersal at the landscape level. Alternatively, differences in the proportion of inter-patch dispersers between areas may arise if the survival rate during dispersal is considerably lower in the NerussaDesna population, or if the immigration rate that compensates the mortality of woodpeckers in the Nerussa-Desna population is lower than that in the Cantabrian population. Further research is needed to assess these hypotheses.

\subsection{Effects of habitat quality on natal and breeding dispersal}

Habitat degradation, measured as patch quality, promoted dispersal of juvenile woodpeckers, as emigration was negatively related to natal patch quality and female settlement was reduced in low quality patches. Habitat quality had lower influence on the settlement of juvenile males, perhaps due to the smaller sample size used in analysis of males compared to that of females, but the high relative importance value of habitat quality suggest that males also tended to settle in high quality patches. These results agree previous studies where natal dispersal has been shown to be a strategy to escape adverse conditions such as the scarcity of food resources (Dickinson \& McGowan 2005, Baglione et al. 2006). However, breeding dispersal was little 
affected by habitat quality, probably because low competitive juveniles are more prone to escape adverse conditions by dispersal than territorial adults.

\subsection{Density-dependent dispersal}

Natal dispersal distance and emigration out of the natal patch were not densitydependent, but juvenile woodpeckers preferred high density patches to settle in. This result may seem counterintuitive, as immigration of dispersers is expected to be inhibited by resident conspecifics (Lambin et al. 2001, Griesser et al. 2008). Immigration into high density patches may arise if dispersers are attracted by conspecifics when deciding where to settle in. Indeed, conspecific attraction is a behavioural mechanism used for territorial migratory birds to choose where to settle (Doligez et al. 2004, Ward \& Schlossberg 2004, Fletcher 2009), and we suggest that it may apply also to resident birds.

\subsection{Conservation implications}

Understanding the ecological processes behind the decline and the persistence of populations is essential to optimise the limited resources available for conservation. The improvement of habitat patch quality can favour the settlement of inter-patch dispersers in fragmented habitats. Habitat quality may be improved by selective cutting of small-diameter oaks, which would reduce competition and allow the growth of the remaining trees, with benefits to both breeding adults and postfledging juvenile woodpeckers (Ciudad et al. 2009, Chapter III). The habitat improvement for this indicator and umbrella species (Angelstam et al. 2004, Roberge \& Angelstam 2006) can benefit also other organisms that depend on old-growth oaks in Europe (Ciudad et al. 2009, Chapter III). On the other hand, conspecific attraction may provide a valuable tool for the conservation of woodpecker populations, as vocalizations might be used to attract juveniles to high quality empty areas (e.g. Ward \& Schlossberg 2004). Nevertheless, the use of conspecific cues with conservation purposes requires caution because of the risk of attracting birds to ecological traps where their fitness can be seriously restricted (Ahlering \& Faaborg 2006). Future investigations should assess 
simultaneously the effects of patch size, patch connectivity, habitat quality and population density on multiple dispersal stages to establish effective conservation actions of populations in fragmented habitats.

\section{REFERENCES}

Ahlering, M. A. \& FAABORG, J. 2006. Avian habitat management meets conspecific attraction: If you build it, will they come? The Auk 123: 301-312.

Angelstam, P., Roberge, J. M., Lõhmus, A., Bergmanis, M., Brazaitis, G., Dönz-Breuss, M., KosińSKI, Z., LÃRmanis, V., LÛKInS, M., MiKusińSKI, G., RaČInSKIS, E., StrazdS, M. \& TRYJANOWSKI, P. 2004. Habitat modelling as a tool for landscape-scale conservation a review of parameters for focal forest birds. Ecological Bulletin 51: 427-453.

Baglione, V., Canestrari, D., Marcos, J. M. \& Ekman, J. 2006. Experimentally increased food resources in the natal territory promotes offspring philopatry and helping in cooperatively breeding carrion crows. Proceedings of the Royal Society of London $B$ 273: 1529-1535.

Bowler, D. E. \& Benton, T. G. 2005. Causes and consequences of animal dispersal strategies: relating individual behaviour to spatial dynamics. Biological Reviews 80 : 205-225.Breininger, D. R. 1999. Florida scrub-jay demography and dispersal in a fragmented landscape. The Auk 116: 520-527.

BRoWN, J. H. \& KODRIC-BRown, A. 1977. Turnover rates in insular biogeography: effect of immigration on extinction. Ecology 58: 445-449.

Burnham, K. P. \& ANDERSON, D. R. 2002. Model selection and multi-model inference: a practical information-theoretic approach. Springer, New York.

Ciudad, C., Robles, H. \& Matthysen, E. 2009. Postfledging habitat selection of juvenile middle spotted woodpeckers: a multi-scale approach. Ecography 32: 676-682.

Clobert, J., Danchin, E., Dhondt, A. A. \& Nichols, J. D. 2001. Dispersal. Oxford University Press, New York. 
Clobert, J., Le Galliard, J-F., Cote, J., Meylan, S. \& Massot, M. 2009. Informed dispersal, heterogeneity in animal dispersal syndromes and the dynamics of spatially structured populations. Ecology Letters 12: 197-209.

CoOPeR, C. B. \& WAlters, J. R. 2002. Experimental evidence of disrupted dispersal causing decline of an Australian passerine in fragmented habitat. Conservation Biology 16: 471-478.

Coulon, A., Fitzpatrick, J. W., Bowman, R. \& Lovette, I. J. 2010. Effects of habitat fragmentation on effective dispersal of Florida scrub-jays. Conservation Biology 24: 1080-1088.

DICKInSON, J. L. \& McGowAN, A. 2005. Winter resource wealth drives delayed dispersal and family-group living in western bluebirds. Proceedings of the Royal Society of London B 272: 2423-2428.

Doligez, B., PÄrt, T., DANChin, E., Clobert, J. \& Gustafsson, L. 2004. Availability and use of public information and conspecific density for settlement decisions in the collared flycatcher. Journal of Animal Ecology 73: 75-87.

FLETCHER JR., R. J. 2009. Does attraction to conspecifics explain the patch-size effect? An experimental test. Oikos 118: 1139-1147.

Garamszegl, L. Z., Calhim, S., Dochtermann, N., Hegyı, G., Hurd, P. L., Jørgensen, C., Kutsukake, N., lajeunesse, M. J., Pollard, K. A., Schielzeth, H., Symonds, M. R. E. \& NAKAgaWA, S. 2009. Changing philosophies and tools for statistical inferences in behavioral ecology. Behavioral Ecology 20: 1363-1375.

GreenWoOd, P. J. 1980. Mating systems, philopatry and dispersal in birds and mammals. Animal Behaviour 28: 1140-1162.

Greenwood, P. J. \& Harvey, P. H. 1982. The natal and breeding dispersal of birds. Annual Review of Ecology and Systematics 13: 1-21.

Griesser, M., Nystrand, M., Eggers, S. \& EkMan, J. 2008. Social constrains limit dispersal and settlement decisions in a group-living bird species. Behavioral Ecology 19: 317324. 
HANSKI, I. \& GILPIN, M. E. 1997. Metapopulation biology: ecology, genetics and evolution. Academic Press, San Diego.

HAUGhLAND, D. L. \& LARSEN, K. W. 2004. Exploration correlates with settlement: red squirrel dispersal in contrasting habitats. Journal of Animal Ecology 73: 1024-1034.

HeINO, M. \& HANSKI, I. 2001. Evolution of migration rate in a spatially realistic metapopulation model. American Naturalist 157: 495-511.

Heino, M., KaitAla, V., RANTA, E. \& Lindström, J. 1997. Synchronous dynamics and rates of extinctions in spatially structured populations. Proceedings of the Royal Society London B 264: 481-486.

IMS, R. A. \& HJermanN, D. Ø. 2001. Condition-dependent dispersal. In: Clobert, J., Danchin, E., Dhondt, A. A. \& Nichols, J. D. (Eds.), Dispersal. Oxford University Press, New York, pp. 203-216.

Koenig, W. D., Van Vuren, D. \& Hooge, P. N. 1996. Detectability, philopatry, and the distribution of dispersal distances in vertebrates. Trends in Ecology and Evolution 11: $514-517$.

KoKKo, H. \& López-SePUlCRe, A. 2006. From individual dispersal to species ranges: perspectives for a changing world. Science 313: 789-791.

KosIŃSKI, Z., KEMPA, M. \& HYBSZ, R. 2004. Accuracy and efficiency of different techniques for censusing territorial middle spotted woodpeckers Dendrocopos medius. Acta Ornithologica 39: 29-34.

KOSSENKO S. M. 2003. A study of mechanisms underlying habitat fragmentation effects on the Middle Spotted Woodpecker Picoides medius: A progress report. In: Pechacek, P. \& d'Oleire-Oltmanns, W. (Eds.), International Woodpecker Symposium. Forschungs-bericht, 48 Nationalparkverwaltung Berchtesgaden, Berchtesgaden, pp. 97-103.

Kossenko S. M. \& KAYgOROdOVA, E. Y. 2001. Effect of habitat fragmentation on distribution, density and breeding performance of the Middle Spotted Woodpecker Dendrocopos medius in the Nerussa-Desna woodland. Entomological Review 81: S161-S166. 
Kossenko, S. M. \& Kaygorodova, E. Y. 2007. Reproduction of the Middle Spotted Woodpecker Dendrocopos medius in the Nerussa-Desna woodland, SW Russia, with particular reference to habitat fragmentation, weather conditions and food supply. Ardea 95: 177-189.

Lambin, X., Aars, J. \& Piertney, S. B. 2001. Dispersal, intraspecific competition, kin competition and kin facilitation: a review of the empirical evidence. In: Clobert, J., Danchin, E., Dhondt, A. A. \& Nichols, J. D. (Eds.), Dispersal. Oxford University Press, New York, pp. 110-122.

Lens, L., Van Dongen, S., Norris, K., Guitiru, M. \& Matthysen, E. 2002. Avian persistence in fragmented rainforest. Science 298: 1236-1238.

LINDENMAYER, D. B. \& FISCHER, J. 2006. Habitat fragmentation and landscape change: an ecological and conservation synthesis. Island Press, Washington.

MATTHYSEn, E. 2005. Density-dependent dispersal in birds and mammals. Ecography 28: 403-416.

Matthysen, E., Adriaensen, F. \& Dhont, A. A. 1995. Dispersal distances of nuthatches, Sitta europaea, in a highly fragmented forest habitat. Oikos 72: 375-381.

McGarigal, K., Cushman, S. A., Neel, M. C. \& Ene, N. 2002. FragstatS: Spatial pattern analysis program for categorical maps, version 3.0. University of Massachusetts, Amherst.

Onrubia, A., Robles, H., Salas, M., González-Quirós, P. \& Olea, P. P. 2004. Pico Mediano, Dendrocopos medius. In: Madroño, A., González, C. \& Atienza, J. C. (Eds.), Libro Rojo de las Aves de España. Dirección General para la Biodiversidad-SEO/BirdLife, Madrid, pp. 304-307.

PASINELLI, G. 2000. Oaks (Quercus sp.) and only oaks? Relations between habitat structure and home range size of the middle spotted woodpecker (Dendrocopos medius). Biological Conservation 93: 227-235.

PASINELLI, G. 2003. Dendrocopos medius Middle Spotted Woodpecker. BWP Update 5: 49-99. 
Pasinelli, G. \& Walters, J. R. 2002. Social and environmental factors affect natal dispersal and philopatry of male red-cockaded woodpeckers. Ecology 83: 22292239.

Pasinelli, G, SChiegG, K. \& Walters, J. R. 2004. Genetic and environmental influences on natal dispersal distance in a resident bird species. American Naturalist 164: 660669.

Pettersson, B. 1985. Extinction of an isolated population of the middle spotted woodpecker Dendrocopos medius (L.) in Sweden and its relation to general theories on extinction. Biological Conservation 32: 335-353.

R Development Core Team. 2009. R: A Language and Environment for Statistical Computing. R Foundation for Statistical Computing, Vienna, Austria.

Roberge, J. M. \& ANGelSTAM, P. 2006. Indicator species between resident forest birds - A cross-regional evaluation in northern Europe. Biological Conservation 130: 134-147.

RoBles, H. 2004. Distribución y estrategias de la vida del pico mediano en una población fragmentada. El papel de la estructura del habitat. PhD thesis. León University, León.

Robles, H. \& OleA, P. P. 2003. Distribución y abundancia del pico mediano (Dendrocopos medius) en una población meridional de la Cordillera Cantábrica. Ardeola 50: 275280.

Robles, H., Ciudad, C., Vera, R., Olea, P. P., Purroy, F. J. \& Matthysen, E. 2007a. Sylvopastoral management and conservation of the middle spotted woodpecker at the south-western edge of its distribution range. Forest Ecology and Management 242: $343-352$.

Robles, H., Ciudad, C., Vera, R. \& Baglione, V. 2007b. No effect of habitat fragmentation on post-fledging, first-year and adult survival in the middle spotted woodpecker. Ecography 30: 685-694.

Robles, H., Ciudad, C., Vera, R., Olea, P. P. \& Matthysen, E. 2008. Demographic responses of middle spotted woodpeckers (Dendrocopos medius) to habitat fragmentation. The Auk 125: 131-139. 
Selonen, V. \& HANSKI, I. K. 2006. Habitat exploration and use in dispersing juvenile flying squirrels. Journal of Animal Ecology 75: 1440-1449.

SMIth, A. T. \& PeAcock, M. M. 1990. Conspecific attraction and the determination of metapopulation colonization rates. Conservation Biology 4: 320-323.

Stephens, P. A., BuskiRk, S. W., Hayward, G. D. \& Martínez del Río, C. 2005. Information theory and hypothesis testing: a call for pluralism. Journal of Applied Ecology 42: 412.

Travis, J. M. J. \& DYthaM, C. 1999. Habitat persistence, habitat availability and the evolution of dispersal. Proceedings of the Royal Society of London B 266: 723-728.

Ward, M. P. \& SChlossberg, S. 2004. Conspecific attraction and the conservation of territorial songbirds. Conservation Biology 18: 519-525.

WATKInSON, A. R. \& SUtherLAND, W. J. 1995. Sources, sinks and pseudo-sinks. Journal of Animal Ecology 64: 126-130.

YÁBER, C. M. \& RABENOLD, K. N. 2002. Effects of sociality on short-distance, female-biased dispersal in tropical wrens. Journal of Animal Ecology 71: 1042-1055. 
Appendix 1. Full model set of analyses examining emigration propensity out of the natal patch in Table 1.

\begin{tabular}{|c|c|c|c|c|c|}
\hline Selected models & Deviance & $K$ & $\mathrm{AICc}$ & $\triangle \mathrm{AICc}$ & Weight \\
\hline Habitat quality, patch size & 25.93 & 4 & 35.0 & 0.00 & 0.157 \\
\hline Habitat quality, population density & 26.99 & 4 & 36.1 & 1.06 & 0.093 \\
\hline Habitat quality, patch size, population density & 24.97 & 5 & 36.6 & 1.62 & 0.070 \\
\hline Habitat quality, patch size, deciduous forest & 25.75 & 5 & 37.4 & 2.40 & 0.047 \\
\hline Habitat quality, patch size, sex & 25.77 & 5 & 37.4 & 2.42 & 0.047 \\
\hline Patch size & 30.81 & 3 & 37.4 & 2.42 & 0.047 \\
\hline Habitat quality, population density, patch connectivity & 25.78 & 5 & 37.4 & 2.43 & 0.047 \\
\hline Habitat quality, population density, patch size & 25.89 & 5 & 37.5 & 2.54 & 0.044 \\
\hline Habitat quality, population density, sex & 26.55 & 5 & 38.2 & 3.20 & 0.032 \\
\hline Habitat quality, population density, deciduous forest & 26.86 & 5 & 38.5 & 3.51 & 0.027 \\
\hline Patch size, patch connectivity & 29.69 & 4 & 38.8 & 3.75 & 0.024 \\
\hline Habitat quality & 32.36 & 3 & 39.0 & 3.98 & 0.022 \\
\hline Habitat quality, patch size, population density, deciduous forest & 24.69 & 6 & 39.1 & 4.07 & 0.021 \\
\hline Habitat quality, patch size, population density, sex & 24.77 & 6 & 39.2 & 4.16 & 0.020 \\
\hline Patch size, deciduous forest & 30.17 & 4 & 39.3 & 4.24 & 0.019 \\
\hline Habitat quality, patch size, population density, patch connectivity & 24.89 & 6 & 39.3 & 4.28 & 0.019 \\
\hline Population density, patch connectivity & 38.47 & 4 & 39.6 & 4.53 & 0.016 \\
\hline Habitat quality, deciduous forest, population density, patch connectivity & 25.38 & 6 & 39.8 & 4.77 & 0.015 \\
\hline Patch size, sex & 30.78 & 4 & 39.9 & 4.85 & 0.014 \\
\hline Patch size, population density & 30.81 & 4 & 39.9 & 4.87 & 0.014 \\
\hline Habitat quality, patch connectivity, population density, sex & 25.63 & 6 & 40.0 & 5.02 & 0.013 \\
\hline Habitat quality, patch size, deciduous forest, sex & 25.64 & 6 & 40.0 & 5.03 & 0.013 \\
\hline Habitat quality, patch size, patch connectivity, sex & 25.65 & 6 & 40.1 & 5.04 & 0.013 \\
\hline Habitat quality, patch size, patch connectivity, deciduous forest & 25.70 & 6 & 40.1 & 5.08 & 0.012 \\
\hline Patch connectivity & 33.60 & 3 & 40.2 & 5.22 & 0.012 \\
\hline Habitat quality, patch connectivity & 31.26 & 4 & 40.3 & 5.32 & 0.011 \\
\hline Habitat quality, sex & 31.75 & 4 & 40.8 & 5.82 & 0.009 \\
\hline Patch size, patch connectivity, deciduous forest & 29.21 & 5 & 40.9 & 5.86 & 0.008 \\
\hline Habitat quality, population density, & 26.49 & 6 & 40.9 & 5.88 & 0.008 \\
\hline Patch size, patch connectivity, population density & 29.36 & 5 & 41.0 & 6.01 & 0.008 \\
\hline Habitat quality, deciduous forest & 32.23 & 4 & 41.3 & 6.30 & 0.007 \\
\hline Patch size, patch connectivity, sex & 29.69 & 5 & 41.3 & 6.34 & 0.007 \\
\hline Patch connectivity, population density, deciduous forest & 29.96 & 5 & 41.6 & 6.61 & 0.006 \\
\hline Patch size, population density, deciduous forest & 30.17 & 5 & 41.8 & 6.82 & 0.005 \\
\hline Patch size, sex, deciduous forest & 30.17 & 5 & 41.8 & 6.82 & 0.005 \\
\hline Habitat quality, patch size, patch connectivity, deciduous forest, population density & 24.56 & 7 & 41.9 & 6.84 & 0.005 \\
\hline Habitat quality, patch size, sex, deciduous forest, population density & 24.57 & 7 & 41.9 & 6.85 & 0.005 \\
\hline Habitat quality, patch size, sex, patch connectivity, population density & 24.74 & 7 & 42.0 & 7.02 & 0.005 \\
\hline Population density, patch connectivity, sex & 30.45 & 5 & 42.1 & 7.10 & 0.005 \\
\hline Population density, patch size, sex & 30.78 & 5 & 42.5 & 7.43 & 0.004 \\
\hline Intercept-only model & 38.15 & 2 & 42.5 & 7.44 & 0.004 \\
\hline Habitat quality, sex, patch connectivity, deciduous forest, population density & 25.34 & 7 & 42.6 & 7.61 & 0.003 \\
\hline Patch connectivity, sex & 33.58 & 4 & 42.7 & 7.64 & 0.003 \\
\hline Patch connectivity, sex, habitat quality & 31.00 & 5 & 42.7 & 7.65 & 0.003 \\
\hline Patch connectivity, deciduous forest & 33.58 & 4 & 42.7 & 7.65 & 0.003 \\
\hline Population density & 36.19 & 3 & 42.8 & 7.81 & 0.003 \\
\hline Habitat quality, patch connectivity, deciduous forest & 31.17 & 5 & 42.8 & 7.82 & 0.003 \\
\hline Habitat quality, patch connectivity, deciduous forest, patch size, sex & 25.54 & 7 & 42.8 & 7.82 & 0.003 \\
\hline Habitat quality, deciduous forest, sex & 31.45 & 5 & 43.1 & 8.10 & 0.003 \\
\hline Patch size, patch connectivity, deciduous fore & 28.77 & 6 & 43.2 & 8.16 & 0.003 \\
\hline Patch size, patch connectivity, deciduous forest, sex & 29.21 & 6 & 43.6 & 8.59 & 0.002 \\
\hline Patch size, patch connectivity, sex, population density & 29.36 & 6 & 43.8 & 8.74 & 0.002 \\
\hline Deciduous forest, patch connectivity, sex, population density & 29.91 & 6 & 44.3 & 9.29 & 0.002 \\
\hline Deciduous forest, patch size, sex, population density & 30.16 & 6 & 44.6 & 9.55 & 0.001 \\
\hline Sex & 37.97 & 3 & 44.6 & 9.59 & 0.001 \\
\hline Deciduous forest & 38.13 & 3 & 44.8 & 9.74 & 0.001 \\
\hline Habitat quality, patch connectivity, deciduous forest, patch size, sex, population density & 24.50 & 8 & 44.9 & 9.85 & 0.001 \\
\hline Population density, deciduous forest & 36.10 & 4 & 45.2 & 10.16 & 0.001 \\
\hline Patch connectivity, deciduous forest, sex & 33.56 & 5 & 45.2 & 10.21 & 0.001 \\
\hline Population density, sex & 36.14 & 4 & 45.2 & 10.21 & 0.001 \\
\hline Habitat quality, patch connectivity, deciduous forest, sex & 30.83 & 6 & 45.2 & 10.21 & 0.001 \\
\hline Patch connectivity, deciduous forest, patch size, sex, population density & 28.75 & 7 & 46.0 & 11.02 & 0.001 \\
\hline Deciduous forest, sex & 37.94 & 4 & 47.0 & 12.00 & 0.000 \\
\hline Deciduous forest, sex, population density & 36.07 & 5 & 47.7 & 12.72 & 0.000 \\
\hline
\end{tabular}


Appendix 2. Full model set of analyses examining male settlement in Table 3.

\begin{tabular}{|c|c|c|c|c|c|}
\hline Selected models & Deviance & $K$ & $\mathrm{AlCc}$ & $\triangle \mathrm{AICc}$ & Weight \\
\hline Population density, patch size & 38.33 & 4 & 47.2 & 0.00 & 0.086 \\
\hline Population density, habitat quality, patch size, patch connectivity & 33.94 & 6 & 47.7 & 0.58 & 0.064 \\
\hline Population density, patch size, patch connectivity & 36.51 & 5 & 47.8 & 0.61 & 0.063 \\
\hline Population density, habitat quality, patch size & 36.80 & 5 & 48.1 & 0.89 & 0.055 \\
\hline Habitat quality & 41.76 & 3 & 48.2 & 1.09 & 0.050 \\
\hline Habitat quality, patch size, patch connectivity & 37.16 & 5 & 48.4 & 1.26 & 0.046 \\
\hline Population density, habitat quality & 39.63 & 4 & 48.5 & 1.30 & 0.045 \\
\hline Population density & 42.21 & 3 & 48.7 & 1.54 & 0.040 \\
\hline Population density, patch size, deciduous forest & 37.95 & 5 & 49.2 & 2.05 & 0.031 \\
\hline Population density, patch size, dispersal distance & 38.02 & 5 & 49.3 & 2.12 & 0.030 \\
\hline Population density, patch size, patch connectivity, deciduous forest & 35.89 & 6 & 49.7 & 2.53 & 0.024 \\
\hline Population density, patch size, patch connectivity, dispersal distance & 36.12 & 6 & 49.9 & 2.76 & 0.022 \\
\hline Habitat quality, patch size, deciduous forest & 38.89 & 5 & 50.1 & 2.99 & 0.019 \\
\hline Habitat quality, deciduous forest & 41.42 & 4 & 50.2 & 3.08 & 0.018 \\
\hline Habitat quality, dispersal distance & 41.43 & 4 & 50.3 & 3.10 & 0.018 \\
\hline Population density, habitat quality, patch size, patch connectivity, deciduous forest & 33.91 & 7 & 50.4 & 3.20 & 0.017 \\
\hline Population density, habitat quality, patch size, patch connectivity, dispersal distance & 33.94 & 7 & 50.4 & 3.22 & 0.017 \\
\hline Population density, habitat quality, patch size, deciduous forest & 36.77 & 6 & 50.6 & 3.40 & 0.016 \\
\hline Population density, habitat quality, patch size, dispersal distance & 36.78 & 6 & 50.6 & 3.42 & 0.016 \\
\hline Habitat quality, patch connectivity & 41.75 & 4 & 50.6 & 3.42 & 0.016 \\
\hline Deciduous forest, habitat quality, patch size, patch connectivity & 36.84 & 6 & 50.6 & 3.47 & 0.015 \\
\hline Population density, deciduous forest & 41.82 & 4 & 50.6 & 3.49 & 0.015 \\
\hline Dispersal distance, habitat quality, patch size, patch connectivity & 36.98 & 6 & 50.8 & 3.62 & 0.014 \\
\hline Population density, habitat quality, patch connectivity & 39.57 & 5 & 50.8 & 3.67 & 0.014 \\
\hline Population density, habitat quality, dispersal distance & 39.58 & 5 & 50.8 & 3.68 & 0.014 \\
\hline Population density, habitat quality, deciduous forest & 39.63 & 5 & 50.9 & 3.73 & 0.013 \\
\hline Population density, dispersal distance & 42.11 & 4 & 50.9 & 3.77 & 0.013 \\
\hline Population density, patch connectivity & 42.19 & 4 & 51.0 & 3.85 & 0.013 \\
\hline Patch size & 44.53 & 3 & 51.0 & 3.86 & 0.012 \\
\hline Population density, patch size, dispersal distance, deciduous forest & 37.88 & 6 & 51.7 & 4.51 & 0.009 \\
\hline Population density, deciduous forest, patch size, patch connectivity, dispersal distance & 35.84 & 7 & 52.3 & 5.12 & 0.007 \\
\hline Habitat quality, deciduous forest, patch connectivity & 41.40 & 5 & 52.7 & 5.50 & 0.005 \\
\hline Habitat quality, dispersal distance, deciduous forest, patch size & 38.89 & 6 & 52.7 & 5.52 & 0.005 \\
\hline Patch size, patch connectivity & 43.93 & 4 & 52.8 & 5.60 & 0.005 \\
\hline Intercept-only model & 48.66 & 2 & 52.9 & 5.75 & 0.005 \\
\hline Population density, patch connectivity, deciduous forest & 41.80 & 5 & 53.1 & 5.90 & 0.004 \\
\hline Population density, dispersal distance, deciduous forest & 41.82 & 5 & 53.1 & 5.92 & 0.004 \\
\hline Population density, dispersal distance, deciduous forest, habitat quality, patch size, patch connectivity & 33.90 & 8 & 53.1 & 5.95 & 0.004 \\
\hline Population density, dispersal distance, deciduous forest, habitat quality, patch size & 36.77 & 7 & 53.2 & 6.05 & 0.004 \\
\hline Dispersal distance, deciduous forest, habitat quality, patch size, patch connectivity & 36.82 & 7 & 53.3 & 6.10 & 0.004 \\
\hline Patch size, dispersal distance & 44.46 & 4 & 53.3 & 6.13 & 0.004 \\
\hline Population density, dispersal distance, habitat quality, patch connectivity & 39.50 & 6 & 53.3 & 6.13 & 0.004 \\
\hline Population density, dispersal distance, patch connectivity & 42.07 & 5 & 53.3 & 6.17 & 0.004 \\
\hline Population density, dispersal distance, habitat quality, deciduous forest & 39.55 & 6 & 53.3 & 6.19 & 0.004 \\
\hline Patch size, deciduous forest & 44.52 & 4 & 53.3 & 6.19 & 0.004 \\
\hline Population density, deciduous forest, habitat quality, patch connectivity & 39.57 & 6 & 53.4 & 6.21 & 0.004 \\
\hline Patch connectivity & 47.97 & 3 & 54.5 & 7.30 & 0.002 \\
\hline Dispersal distance, deciduous forest, habitat quality, patch connectivity & 41.29 & 6 & 55.1 & 7.93 & 0.002 \\
\hline Patch size, patch connectivity, dispersal distance & 43.86 & 5 & 55.1 & 7.96 & 0.002 \\
\hline Deciduous forest & 48.65 & 3 & 55.1 & 7.98 & 0.002 \\
\hline Dispersal distance & 48.66 & 3 & 55.1 & 7.99 & 0.002 \\
\hline Patch size, patch connectivity, deciduous forest & 43.93 & 5 & 55.2 & 8.03 & 0.002 \\
\hline Population density, dispersal distance, deciduous forest, patch connectivity & 41.80 & 6 & 55.6 & 8.44 & 0.001 \\
\hline Patch size, dispersal distance, deciduous forest & 44.42 & 5 & 55.7 & 8.52 & 0.001 \\
\hline Population density, dispersal distance, deciduous forest, habitat quality, patch connectivity & 39.46 & 7 & 55.9 & 8.75 & 0.001 \\
\hline Patch connectivity, deciduous forest & 47.96 & 4 & 56.8 & 9.63 & 0.001 \\
\hline Patch connectivity, dispersal distance & 47.96 & 4 & 56.8 & 9.63 & 0.001 \\
\hline Dispersal distance, deciduous forest & 48.65 & 4 & 57.5 & 10.32 & 0.000 \\
\hline Dispersal distance, deciduous forest, patch size, patch connectivity & 43.85 & 6 & 57.6 & 10.49 & 0.000 \\
\hline Dispersal distance, deciduous forest, patch connectivity & 47.95 & 5 & 59.2 & 12.05 & 0.000 \\
\hline
\end{tabular}


Appendix 3. Full model set of analyses examining female settlement in Table 3.

\begin{tabular}{|c|c|c|c|c|c|}
\hline Selected models & Deviance & K & $\mathrm{AlCc}$ & $\triangle \mathrm{AICC}$ & Weight \\
\hline Population density, habitat quality & 54.54 & 4 & 63.1 & 0.00 & 0.127 \\
\hline Population density, habitat quality, patch size, patch connectivity & 50.98 & 6 & 64.3 & 1.14 & 0.072 \\
\hline Population density & 58.02 & 3 & 64.4 & 1.24 & 0.069 \\
\hline Population density, patch size & 56.10 & 4 & 64.7 & 1.57 & 0.058 \\
\hline Population density, patch size, habitat quality & 53.83 & 5 & 64.7 & 1.61 & 0.057 \\
\hline Population density, habitat quality, patch connectivity & 54.25 & 5 & 65.2 & 2.03 & 0.046 \\
\hline Population density, habitat quality, dispersal distance & 54.43 & 5 & 65.3 & 2.21 & 0.042 \\
\hline Population density, habitat quality, deciduous forest & 54.54 & 5 & 65.4 & 2.31 & 0.040 \\
\hline Population density, Patch size, patch connectivity & 54.82 & 5 & 65.7 & 2.59 & 0.035 \\
\hline Habitat quality & 59.44 & 3 & 65.8 & 2.67 & 0.034 \\
\hline Population density, deciduous forest & 57.93 & 4 & 66.5 & 3.39 & 0.023 \\
\hline Population density, patch connectivity & 57.95 & 4 & 66.6 & 3.42 & 0.023 \\
\hline Population density, dispersal distance & 57.97 & 4 & 66.6 & 3.43 & 0.023 \\
\hline Population density, habitat quality, dispersal distance, patch size, patch connectivity & 50.85 & 7 & 66.6 & 3.46 & 0.023 \\
\hline Population density, habitat quality, deciduous forest, patch size, patch connectivity & 50.96 & 7 & 66.7 & 3.58 & 0.021 \\
\hline Population density, patch size, deciduous forest & 55.99 & 5 & 66.9 & 3.77 & 0.019 \\
\hline Population density, patch size, dispersal distance & 56.07 & 5 & 67.0 & 3.85 & 0.019 \\
\hline Population density, patch size, deciduous forest, habitat quality & 53.83 & 6 & 67.1 & 3.99 & 0.017 \\
\hline Population density, patch size, dispersal distance, habitat quality & 53.83 & 6 & 67.1 & 3.99 & 0.017 \\
\hline Population density, patch connectivity, dispersal distance, habitat quality & 53.90 & 6 & 67.2 & 4.06 & 0.017 \\
\hline Population density, patch connectivity, deciduous forest, habitat quality & 54.25 & 6 & 67.5 & 4.41 & 0.014 \\
\hline Habitat quality, patch size & 59.07 & 4 & 67.7 & 4.53 & 0.013 \\
\hline Population density, habitat quality, dispersal distance, deciduous forest & 54.42 & 6 & 67.7 & 4.59 & 0.013 \\
\hline Habitat quality, deciduous forest & 59.19 & 4 & 67.8 & 4.67 & 0.012 \\
\hline Population density, patch size, deciduous forest, patch connectivity & 54.53 & 6 & 67.8 & 4.69 & 0.012 \\
\hline Habitat quality, patch connectivity & 59.32 & 4 & 67.9 & 4.79 & 0.012 \\
\hline Habitat quality, dispersal distance & 59.41 & 4 & 68.0 & 4.88 & 0.011 \\
\hline Population density, patch size, dispersal distance, patch connectivity & 54.81 & 6 & 68.1 & 4.97 & 0.011 \\
\hline Habitat quality, patch size, patch connectivity & 57.52 & 5 & 68.4 & 5.29 & 0.009 \\
\hline Population density, dispersal distance, deciduous forest & 57.86 & 5 & 68.8 & 5.63 & 0.008 \\
\hline Population density, deciduous forest, patch connectivity & 57.86 & 5 & 68.8 & 5.64 & 0.008 \\
\hline Population density, dispersal distance, patch connectivity & 57.93 & 5 & 68.8 & 5.70 & 0.007 \\
\hline Intercept-only model & 64.88 & 2 & 69.1 & 5.92 & 0.007 \\
\hline Population density, patch size, deciduous forest, patch connectivity, dispersal distance, habitat quality & 50.81 & 8 & 69.1 & 5.96 & 0.006 \\
\hline Population density, patch size, deciduous forest, dispersal distance & 55.97 & 6 & 69.3 & 6.13 & 0.006 \\
\hline Patch size & 63.21 & 3 & 69.6 & 6.44 & 0.005 \\
\hline Population density, patch size, deciduous forest, dispersal distance, habitat quality & 53.83 & 7 & 69.6 & 6.44 & 0.005 \\
\hline Population density, deciduous forest, patch connectivity, dispersal distance, habitat quality & 53.89 & 7 & 69.6 & 6.51 & 0.005 \\
\hline Patch size, habitat quality, deciduous forest & 58.85 & 5 & 69.8 & 6.63 & 0.005 \\
\hline Patch connectivity, habitat quality, deciduous forest & 59.04 & 5 & 70.0 & 6.81 & 0.004 \\
\hline Patch size, habitat quality, dispersal distance & 59.06 & 5 & 70.0 & 6.84 & 0.004 \\
\hline Deciduous forest, habitat quality, dispersal distance & 59.18 & 5 & 70.1 & 6.96 & 0.004 \\
\hline Patch connectivity, habitat quality, dispersal distance & 59.21 & 5 & 70.1 & 6.99 & 0.004 \\
\hline Population density, patch size, deciduous forest, patch connectivity, dispersal distance & 54.53 & 7 & 70.3 & 7.15 & 0.004 \\
\hline Patch size, deciduous forest, patch connectivity, habitat quality & 57.31 & 6 & 70.6 & 7.47 & 0.003 \\
\hline Patch size, dispersal distance, patch connectivity, habitat quality & 57.50 & 6 & 70.8 & 7.66 & 0.003 \\
\hline Patch connectivity & 64.46 & 3 & 70.8 & 7.68 & 0.003 \\
\hline Population density, patch connectivity, dispersal distance, deciduous forest & 57.82 & 6 & 71.1 & 7.98 & 0.002 \\
\hline Deciduous forest & 64.85 & 3 & 71.2 & 8.07 & 0.002 \\
\hline Dispersal distance & 64.88 & 3 & 71.2 & 8.10 & 0.002 \\
\hline Patch size, patch connectivity & 62.81 & 4 & 71.4 & 8.28 & 0.002 \\
\hline Patch size, dispersal distance & 63.06 & 4 & 71.7 & 8.52 & 0.002 \\
\hline Patch size, deciduous forest & 63.19 & 4 & 71.8 & 8.66 & 0.002 \\
\hline Patch size, deciduous forest, habitat quality, dispersal distance & 58.84 & 6 & 72.1 & 9.00 & 0.001 \\
\hline Patch connectivity, deciduous forest, habitat quality, dispersal distance & 58.96 & 6 & 72.3 & 9.12 & 0.001 \\
\hline Patch connectivity, dispersal distance & 64.43 & 4 & 73.0 & 9.89 & 0.001 \\
\hline Patch connectivity, deciduous forest & 64.43 & 4 & 73.0 & 9.89 & 0.001 \\
\hline Patch size, deciduous forest, patch connectivity, dispersal distance, habitat quality & 57.31 & 7 & 73.1 & 9.92 & 0.001 \\
\hline Dispersal distance, deciduous forest & 64.85 & 4 & 73.5 & 10.31 & 0.001 \\
\hline Patch size, patch connectivity, dispersal distance & 62.67 & 5 & 73.6 & 10.44 & 0.001 \\
\hline Patch size, patch connectivity, deciduous forest & 62.81 & 5 & 73.7 & 10.59 & 0.001 \\
\hline Dispersal distance, deciduous forest, patch size & 63.02 & 5 & 73.9 & 10.80 & 0.001 \\
\hline Dispersal distance, deciduous forest, patch connectivity & 64.39 & 5 & 75.3 & 12.17 & 0.000 \\
\hline Dispersal distance, deciduous forest, patch connectivity, patch size & 62.66 & 6 & 76.0 & 12.82 & 0.000 \\
\hline
\end{tabular}


Appendix 4. Full model set of analyses examining emigration propensity from the breeding territory in Table 5.

\begin{tabular}{lccccc}
\hline Selected models & Deviance & $K$ & AICc & AAICc & Weight \\
\hline Patch size & 81.38 & 4 & 90.0 & 0.00 & 0.290 \\
Patch size, patch connectivity & 81.02 & 5 & 91.9 & 1.95 & 0.110 \\
Patch size, population density & 81.20 & 5 & 92.1 & 2.13 & 0.100 \\
Patch size, sex & 81.38 & 5 & 92.3 & 2.30 & 0.092 \\
Intercept-only model & 86.37 & 3 & 92.7 & 2.74 & 0.074 \\
Patch connectivity & 84.65 & 4 & 93.3 & 3.26 & 0.057 \\
Population density & 84.94 & 4 & 93.5 & 3.56 & 0.049 \\
Patch connectivity, population density & 82.88 & 5 & 93.8 & 3.81 & 0.043 \\
Patch connectivity, population density, patch size & 80.77 & 6 & 94.1 & 4.08 & 0.038 \\
Patch size, patch connectivity, sex & 81.02 & 6 & 94.3 & 4.33 & 0.033 \\
Patch size, population density, sex & 81.20 & 6 & 94.5 & 4.51 & 0.030 \\
Sex & 86.36 & 4 & 95.0 & 4.98 & 0.024 \\
Sex, patch connectivity & 84.62 & 5 & 95.5 & 5.55 & 0.018 \\
Sex, population density & 84.87 & 5 & 95.8 & 5.79 & 0.016 \\
Sex, population density, patch connectivity & 82.60 & 6 & 95.9 & 5.91 & 0.015 \\
Sex, population density, patch connectivity, patch size & 80.76 & 7 & 96.5 & 6.53 & 0.011 \\
\hline
\end{tabular}




\section{CAPÍTULO III - SELECCIÓN DEL HÁBITAT DE LOS JUVENILES}
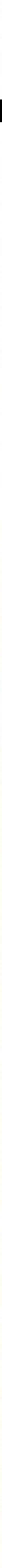


\title{
POSTFLEDGING HABITAT SELECTION OF JUVENILE MIDDLE SPOTTED WOODPECKERS: A MULTI-SCALE APPROACH
}

\begin{abstract}
Despite its relevance for the persistence of populations, the ecological mechanisms underlying habitat use decisions of juvenile birds are poorly understood. We examined postfledging habitat selection of radio-tracked juvenile middle spotted woodpeckers (Dendrocopos medius) at multiple hierarchically-nested spatial scales in NW Spain. At the landscape and home range scales, old oak forest was the most used and selected habitat, young oak forests and pine plantations were avoided, and riverside forests were used as available. At a lower scale, birds selected larger diameter trees for foraging. Home ranges had higher densities of large deciduous trees (mainly oaks Quercus spp., but also poplars Populus spp. and willows Salix spp. $>22 \mathrm{~cm}$ and $>33 \mathrm{~cm} \mathrm{DBH}$ ) selected for foraging by juveniles than non-used areas. These results suggest that foraging conditions might drive, at least partly, habitat use decisions by juvenile birds. We also discuss the potential influence of intraspecific competition, the search for a future breeding territory in the early postfledging period and predation avoidance on habitat use decisions by juvenile birds. Contrary to previous studies on migrant forest birds, postfledging juvenile woodpeckers selected the same habitat as for the breeding adults (i.e. old oak forest), indicating that migrant and resident specialist avian species may require different conservation actions. Conservation strategies of woodpecker populations should consider the protection of old oak forests with high densities of large trees to provide suitable habitat to breeding adults and postfledging juveniles. The habitat improvement for this indicator and umbrella species would also favour other organisms that depend on characteristics of old-growth oak forests.
\end{abstract}

\section{SELECCIÓN DE HÁBITAT DE JUVENILES DE PICO MEDIANO DURANTE EL PERIODO POST-VUELO: UN ENFOQUE A MÚLTIPLES ESCALAS}

RESUMEN.- A pesar de su relevancia para la persistencia de las poblaciones, los mecanismos ecológicos que están detrás de las decisiones de uso del hábitat de los juveniles de aves son escasamente conocidos. Examinamos la selección del hábitat de juveniles radio-marcados de pico mediano (Dendrocopos medius) durante el periodo post-vuelo a múltiples escalas jerárquicamente anidadas en el NW de España. A escalas de paisaje y de área de campeo, los robledales viejos fue el hábitat más usado y seleccionado, los robledales jóvenes y las plantaciones de pinos fueron evitados, y los bosques de ribera fueron usados de acuerdo a su disponibilidad. A una escala menor, las aves seleccionaron los árboles de mayor diámetro para alimentarse. Las áreas de campeo de los juveniles tuvieron mayores densidades de árboles caducifolios grandes (principalmente robles Quercus spp., pero también chopos Populus spp. y sauces Salix spp. $>22 \mathrm{~cm}$ y $>33 \mathrm{~cm}$ DBH) que las áreas no usadas. Estos resultados sugieren que las condiciones de forrajeo pueden dirigir, al menos parcialmente, las decisiones de uso de hábitat de los juveniles. Además discutimos la influencia potencial de la competencia intraespecífica, la búsqueda de futuros territorios de cría durante el periodo post-vuelo y la evitación de la depredación en las decisiones de uso del hábitat de los juveniles. Contrariamente a estudios previos con aves forestales migratorias, los picos juveniles seleccionaron durante el periodo post-vuelo el mismo hábitat que el de los adultos reproductores (i.e. robledales viejos), lo cual indica que las especies de aves especialistas migratorias y residentes pueden requerir diferentes acciones de conservación. Las estrategias de conservación de las poblaciones de pico mediano deberían considerar la protección de los robledales viejos con elevadas densidades de árboles grandes que proveen de hábitat adecuado tanto a los adultos reproductores como a los juveniles. La mejora del hábitat para esta especie indicadora y paraguas podría favorecer también a otros organismos que dependen de las características de los robledales maduros. 


\section{INTRODUCTION}

Animal conservation requires the protection of critical resources through all life stages (Anders et al. 1998, Vega Rivera et al. 1998). In birds, most studies have investigated habitat use by adults during the breeding season, whereas juvenile requirements in the postfledging period are poorly known (Vega Rivera et al. 1998). As juvenile survival and recruitment are important components of population growth (Porneluzi \& Faaborg 1999), the protection of habitats where young can cover their requirements has serious implications for the persistence of endangered populations. Indeed, conservation strategies based on the protection of breeding habitats can be unsuccessful in maintaining endangered populations if juveniles use different habitats than those used by adults for breeding (Anders et al. 1998, Vega Rivera et al. 1998, White et al. 2005). A better understanding of the habitat requirements of juvenile birds is therefore needed for establishing suitable conservation actions.

Juvenile birds may undergo high mortality rates due to starvation associated with poor foraging conditions in the postfledging period, either when young are partly fed by the parents or after independence, when juveniles must search for food by themselves farther away from the natal area (Korpimäki \& Lagerström 1988, Wiens et al. 2006). Besides, juveniles in worse body condition are subjected to high predation rates in some bird species (e.g. Naef-Daenzer et al. 2001, Robles et al. 2007a). Thus, food supply, and consequently foraging conditions, are expected to be among the most important environmental factors influencing habitat selection by juvenile birds (Vega Rivera et al. 1998, White et al. 2005). Besides, other factors such as predation, intraspecific competition or the search for a future breeding territory may also influence habitat use decisions in birds (Vega Rivera et al. 1998, Lambin et al. 2001, White et al. 2005).

So far, only a few studies have examined habitat use of juvenile birds (Anders et al. 1998, Ganey et al. 1998, Vega Rivera et al. 1998, Overskaug et al. 1999, Lang et al. 2002, Cohen \& Lindell 2004, Kershner et al. 2004, Berkeley et al. 2007). These studies suggest that juvenile habitat use decisions are driven by food supply and foraging conditions, but paradoxically, there is a lack of information on foraging habitat selection of juvenile birds, necessary to shed light on this hypothesis. White et al. 
(2005) provided one exception, as they examined foraging habitat selection of juvenile Swainson's thrushes (Catharus ustulatus) at the patch scale. However, studies conducted at a single spatial scale are limited because differences in scale can affect results and their interpretation (Swenson 1993). A better approach is to investigate habitat selection at multiple hierarchically-nested spatial scales (Swenson 1993, Rolstad et al. 2000, Luck 2002).

We examined habitat selection of radio-tracked juvenile middle spotted woodpeckers (Dendrocopos medius) at multiple hierarchically-nested spatial scales in Cantabrian Mountains (NW Spain). The middle spotted woodpecker is a resident bird associated with old deciduous forests of the western Palaearctic (Pasinelli 2000, 2003, Robles et al. 2007b) that has been shown to be sensitive to anthropogenic habitat changes (Pettersson 1985, Robles et al. 2007b, 2008). Its habitat specialisation is based on the preference for large diameter rough-bark deciduous trees for foraging (Pasinelli \& Hegelbach 1997, Hertel 2003, Robles et al. 2007b). The first weeks after fledging are critical for juvenile survival, with fledglings in poor body condition experiencing higher mortality rates (Robles et al. 2007a). At the largest scale we assessed home range selection within the surrounding landscape, then we assessed selection of woodland type within the home range, and lastly we assessed foraging tree selection. We also compared, based on foraging tree selection, the structure of the vegetation between home ranges and non-used areas by juvenile woodpeckers. Because this woodpecker is an indicator of bird species richness and abundances in Palaearctic deciduous forests (Roberge \& Angelstam 2006), understanding habitat use decisions by juvenile middle spotted woodpeckers in the postfledging period may have implications for conservation of other forest birds in Europe.

\section{METHODS}

\subsection{Study area}

The study was carried out in a $500 \mathrm{Km}^{2}$ area in the southern Cantabrian Mountains (NW Spain, $42^{\circ} 41^{\prime} \mathrm{N}, 5^{\circ} 2^{\prime} \mathrm{W}, 900-1250 \mathrm{~m}$ a.s.l.). This area is composed by a mosaic of patches of forests, scrublands, pastures, cereal croplands, rocky and urban areas. 
Potential breeding habitats for the middle spotted woodpecker are mature oak (Quercus spp.) forests and oak dehesas, a traditional forested pasture where large trees are preserved for acorn production and for sheltering the livestock (Robles et al. 2007b). Heavily-disturbed young oak forests and other forested habitats (pine plantations Pinus spp. and riverside forests Populus spp., Salix spp., Fraxinus spp.) are not used for breeding (Robles \& Olea 2003, Onrubia et al. 2004, Robles et al. 2007b).

\subsection{Bird banding, radiotracking and home range estimation}

This study is based on the data gathered from 13 fledglings marked in 8 nests (one to three birds per brood) when they were 20-23 days old (Robles et al. 2007a). The fledglings were radiotracked during the postfledging period (late spring-summer) of 2003 ( $n=1$ fledgling), 2004 ( $n=7$ fledglings from 4 broods) and 2005 ( $n=5$ fledglings from 3 broods). Transmitters BD-2 (Holohil Systems Ltd., Canada) that weigh either 1.6 $\mathrm{g}$ or $1.8 \mathrm{~g}$ ( $3 \%$ of average nestling mass) were attached with a leg-loop elastic harness to the young (Robles et al. 2007a). Average nestling weight (53 g) at the time of radioattachment was similar to that of adult woodpeckers (Pasinelli 2003). Juveniles were sexed by molecular methods (Robles et al. 2007a). Juveniles were located once daily after fledging with four-element hand-held Yagi antennas and RX-98 tracking receivers (Televilt, Sweden) until the death of the bird (one fledgling was predated), the end of the transmitter battery life ( $n=11$ fledglings) or the disappearance of the radio-signal ( $n=1$ ) (Robles et al. 2007a). Subsequent locations of each individual were alternated between morning and afternoon to ensure that birds were checked during different day time periods (White et al. 2005). Birds were located by the homing method (Fuller et al. 2005). Locations were confirmed by visual and/or auditive contact. In most cases (> 99\%), we could encircle the tree where the birds were in. In the remaining few cases, we could estimate the location of the birds within a circle $<30 \mathrm{~m}$. Locations were recorded by a global positioning system (GPS, model garmin e-legend) with an error $<20$ m estimated from experimental trials.

We estimated home ranges using 95\% fixed Kernel estimator in Ranges V (Kenward \& Hodder 1996). To determine the independence of home ranges that overlapped, we used the "dynamic interaction analysis" in Ranges V (Kenward \& Hodder 1996). This 
analysis provides a "cohesion index" for the tendency of pairs of animals to be close together at the same time by comparing the observed and possible distances between animals. The observed and possible distances are compared by Jacobs' index, which ranges from +1 (maximum positive association) to -1 (maximum negative association), 0 representing a chance association. Two pairs of siblings were not independent (index $\geq 0.8$ ), so we randomly discarded one individual of each pair. The remaining 11 home ranges were independent (index $<0.2$ ). Using data sets containing < 30 locations may bias home range estimations because kernel range estimates are positively biased for small sample sizes (Worton 1987). Thus, we also discarded another individual because only 22 locations could be recorded. Overall, habitat selection was examined for 10 individuals from 8 broods, and home ranges were calculated based on 66 (range $=35$ 82) locations on average.

\subsection{Home range selection}

At the landscape scale, we examined whether juveniles established the home ranges at random ("second-order selection" sensu Johnson 1980). We estimated the availability of each habitat type separately for every bird. To do this, we defined a circle centred on the centroid of the home range and with radius 1.5 times the maximum distance to its edge (Menzel et al. 2001 provide a similar method). Then, we compared the proportion of each type of habitat within the home range (usage) and within the circle that enclosed the home range (availability). We found qualitatively similar habitat selection results when using $1.5 x$ and $2 x$ radii, but we used $1.5 x$ for all juveniles because a $2 x$ map was missing for two juveniles. We believe using a defined centroid is more accurate than considering as available the habitat within the whole study area, because the entire area was probably not available to every individual (Aebischer et al. 1993, Jones 2001).

A detailed habitat map was generated at scale 1:2000 from geo-referenced aerial photographs of the Junta de Castilla y León (2001, 2002 and 2004) by using ArcGIS ver. 9.2 (ESRI, <www.esri.com>). Map reliability was verified in the field. We categorised five habitat types: old oak forests (mature oak forest and oak dehesas), young oak forests, pine plantations (Pinus spp), riverside forests (dominated by Populus spp., with 
Salix spp. and Fraxinus spp. in lower proportion), and open habitats (scrublands, pastures, cereal croplands, rocky and urban areas). Open habitats were excluded from the analysis because only forested habitats are used by the forest-specialist middle spotted woodpecker.

Habitat selection was investigated by compositional analysis (Aebischer et al. 1993) in Resource Selection for Windows beta 8.4 (Leban 1999). Using individuals rather than locations as unit samples, compositional analysis ranks habitats in selection order using the log ratios from used to available values for each habitat, and has the advantage of avoiding the non-independence of proportions of habitat use. Zero proportions were replaced with 0.00001 (Leban 1999). Additionally, an absolute selection value for each habitat type was obtained using the Jacobs' (1974) index, calculated as

$$
J=(r-p) /[(r+p)-2 r p]
$$

where $r$ and $p$ are the proportions of used and available habitat, respectively. An index value of 0 indicates no selection, +1 maximum selection and -1 maximum avoidance. To assess statistical significance we tested whether the $95 \%$ confidence intervals of the obtained values included zero using a one-sample t-test.

\subsection{Selection within home ranges}

At a finer scale, we assessed habitat selection by juvenile woodpeckers within home ranges ("third-order selection" sensu Johnson 1980). Usage was considered as the proportion of locations in each habitat type and availability as the proportion of each type of habitat in the home range. Data analysis follows the same procedures as for home range selection.

We performed an additional analysis to test whether the results on habitat selection were consistent between sexes and study scales (home range and landscape). The response variable was the Jacobs' index for old oak forest (i.e. the most selected habitat), and its relation with the explanatory variables was modeled by using linear mixed effects (LME) models (Pinheiro \& Bates 2000). LME models were fitted with the "Ime" function in S-Plus 2000 (MathSoft, Seattle, WA, USA). Data of all the 13 juveniles were included in the analysis, and individual identity nested within 
brood identity, in addition to brood identity, were fitted as random terms to control for multiple measurements within the same individuals and broods.

\subsection{Foraging tree selection}

At the finest scale, we assessed the foraging tree selection in the woodlands used by juvenile woodpeckers within the home ranges ("fourth-order selection" sensu Johnson 1980). Once a bird was located, data on foraging tree use were recorded when possible. To reduce dependence between observations only one observation per tree was considered, and observations from different trees were distanced at least 10 minutes (Rudolph et al. 2002, Robles et al. 2007b). We collected data from 369 foraging trees used by 13 juveniles and in each case identified the closest non-used tree. We only considered oaks, poplars (Populus spp.) and willows (Salix spp.) $\geq 7 \mathrm{~cm}$ $\mathrm{DBH}$ (diameter at breast height, measured at $1.3 \mathrm{~m}$ above ground) as available, because other tree species and smaller trees were not used by the woodpeckers. We recorded the species, diameter $(\mathrm{DBH})$ and condition (alive or decayed: trunk partially debarked and/or with polyporous fungi and/or completely dead) of each tree.

The characteristics of the trees used and non-used for foraging was compared by generalized linear mixed models (GLMM) with a binomial error distribution and a logistic link function. GLMM were fitted with the gImmPQL function from MASS library in R statistical software (<www.R-project.org $>$ ). The binomial dependent variable was tree-use ( 1 used, 0 non-used). The tree species, tree diameter and tree condition were fitted as fixed terms. We collected data from two trees per every foraging location (the used tree and the closest non-used tree). Thus, foraging location identity was included as a random term to control for multiple observations within the same locations. Individual identity was also included as a random term to control for multiple measurements within the same individuals.

\subsection{Vegetation structure}

Based on the results of foraging tree selection, we characterised the vegetation structure in home ranges $(n=10)$ and in areas not used by juveniles $(n=7)$. Non-used 
areas ( $\sim 30$ ha each) were randomly chosen within the circles enclosing post-dispersal habitat availability at the landscape scale. Vegetation structure was determined by establishing a network of circular plots of 0.04 ha (11.2 $\mathrm{m}$ radius) $\geq 100 \mathrm{~m}$ apart in each area (home range or non-used area) (Robles et al. 2007b). The number of plots (7 - 53) varied with the surface and habitat heterogeneity of the home ranges and non-used areas. The species, diameter and condition of all the trees were recorded in each plot. Only oaks, poplars and willows measuring $\geq 10 \mathrm{~cm} \mathrm{DBH}(97 \%$ of the foraging trees had $\geq 10 \mathrm{~cm} \mathrm{DBH}$ ) were considered, as other tree species were not used by juvenile woodpeckers for foraging.

We measured several habitat structure variables to quantify important features of large and decayed trees: (1) the density of trees $\geq 22 \mathrm{~cm} \mathrm{DBH} \mathrm{(75 \%} \mathrm{of} \mathrm{the} \mathrm{foraging}$ trees had $\geq 22 \mathrm{~cm} \mathrm{DBH}$ ) and (2) $\geq 33 \mathrm{~cm} \mathrm{DBH}$ (i.e. the median DBH of the foraging trees), (3) the basal area $\left(\mathrm{m}^{2} \mathrm{ha}^{-1}\right)$ of trees $\geq 10 \mathrm{~cm} \mathrm{DBH}$, and (4) the density of decayed trees $\geq 10 \mathrm{~cm}$ DBH. The differences in habitat structure between home ranges and non-used areas were tested using Mann-Whitney U-test in SPSS 14.0 (SPSS 2005).

\section{RESULTS}

\subsection{Home range selection}

At the landscape scale, home ranges were not randomly established $(\lambda=0.16, \mathrm{df}=$ 3, $P<0.001)$. The compositional analysis revealed that old oak forests were significantly selected over all the remaining habitats (young oak forests, riverside forests and pine plantations), and young oak forests over pine plantations (Table 1). The results of the Jacobs' index indicated that old oak forests were the only positively selected habitat, while young oak forests and pine plantations were significantly avoided, and riverside forests were used according to availability (Fig. 1).

\subsection{Selection within home ranges}

Habitat use within home ranges differed significantly from a random pattern $(\lambda=$ $0.19, \mathrm{df}=3, P<0.001$ ). Old oak forests were significantly selected over all the remaining habitats (Table 1). The results of the Jacobs' index indicated that juvenile 
woodpeckers positively selected old oak forests and significantly avoided young oak forests and pine plantations. Riverside forests were used as available (Fig. 1).

The selection for old oak forests was consistent between sexes (parameter estimate $\pm \mathrm{SE}=-0.032 \pm 0.034 \mathrm{df}=4, t=-0.937, P=0.402$ ). Old oak forests were more positively selected at the landscape scale than at the home range scale (parameter estimate $\pm \mathrm{SE}=-0.139 \pm 0.030, \mathrm{df}=12, t=-4.725, P<0.001 ;$ Fig. 1$)$.

Table 1. Compositional selection rankings for second- and third-order habitat selection (home range selection and selection within home ranges, respectively) by 10 juvenile middle spotted woodpeckers. Habitats (old oak forest, young oak forest, pine plantation, riverside forest) were ranked from 0 to 3 (most positively selected). Different letters indicate differences in use among habitats at $P \leq 0.05$. Selection ranking is meaningless for habitats with the same letter (Aebischer et al. 1993).

\begin{tabular}{lccccc}
\hline & & \multicolumn{5}{c}{ Habitat type } \\
\cline { 3 - 6 } & $\chi_{3}^{2}$ & Old oak & Young oak & Pine & Riverside \\
\hline Second-order selection & 18.31 & $3 a$ & $2 b$ & oc & $1 b c$ \\
Third-order selection & 16.86 & $3 a$ & $2 b$ & 0b & $1 b$ \\
\hline
\end{tabular}

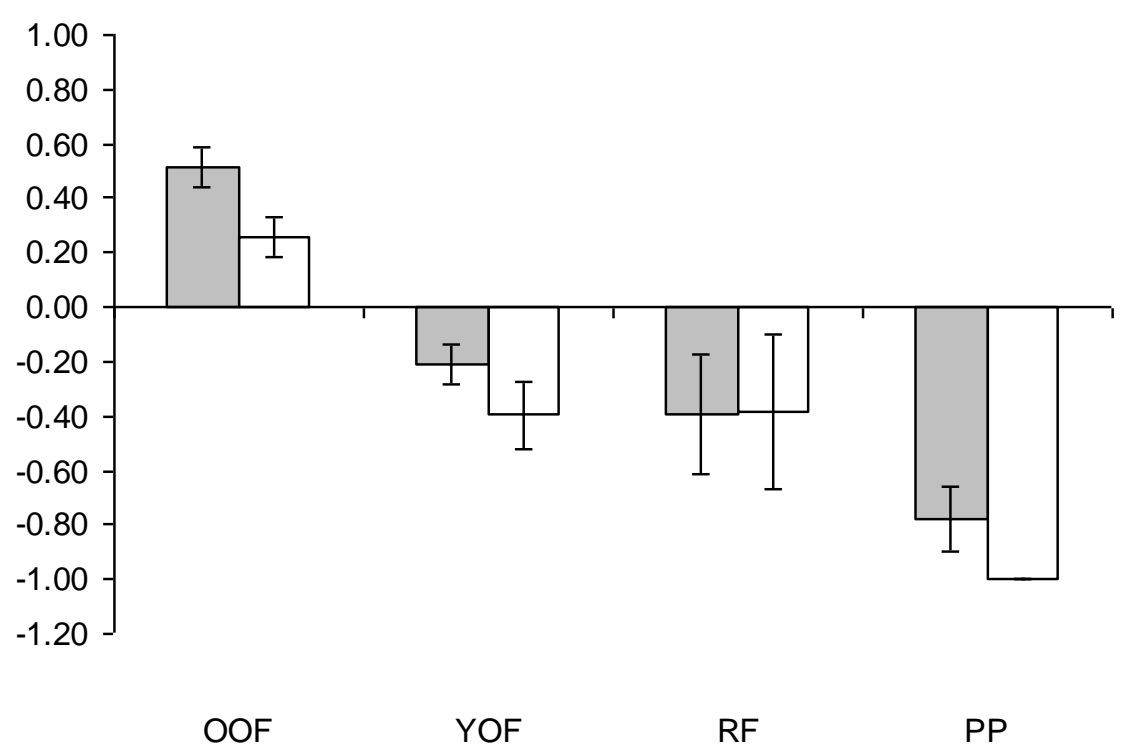

Fig. 1. Mean $( \pm S E)$ values of Jacobs' index for each habitat used by juvenile middle spotted woodpeckers showing second- and third-order (filled and white bars, respectively) habitat selection (home range selection and selection within home ranges, respectively). The value +1 is maximum selection and -1 is maximum avoidance; 0 indicates no selection. Numbers show the number of birds used in calculations. Asterisks indicate significant differences from zero $(P<0.05)$. OOF: old oak forest, YOF: young oak forest, RF: riverside forest, PP: pine plantation. 


\subsection{Foraging tree preferences}

Juvenile woodpeckers foraged on oaks, poplars and willows, whereas pines and ashes were not used. Seventy five per cent of the used trees were alive. GLMM analysis indicated that tree diameter through its interaction with tree condition significantly affected the use of trees (Table 2). Birds selected decayed trees and larger diameters of living trees for foraging (Table 2, Fig. 2). Results were consistent between tree species (all $P>0.05$; Table 2 ).

Table 2. GLMM results comparing 369 trees used by 13 juvenile middle spotted woodpeckers for foraging and 369 non-used trees. A binomial error distribution and a logistic link function were used. Tree diameter at breast height (DBH), tree condition (decayed, alive) and tree species (poplar, oak, willow) were fitted as fixed terms. Individual and foraging location identity were included as random terms to control for multiple observations within the same individuals and foraging locations.

\begin{tabular}{lccrrr}
\hline & Parameter & SE & df & \multicolumn{1}{c}{$t$} & $P$ \\
\hline Intercept & 1.202 & 0.649 & 364 & 1.854 & 0.065 \\
DBH & -0.006 & 0.006 & 364 & -1.045 & 0.297 \\
Tree condition (alive) & -1.873 & 0.416 & 364 & -4.498 & 0.000 \\
DBH x tree condition (alive) & 0.037 & 0.008 & 364 & 4.623 & 0.000 \\
Tree species (oak) & -0.326 & 0.537 & 364 & -0.608 & 0.544 \\
Tree species (willow) & -1.668 & 1.276 & 364 & -1.307 & 0.191 \\
\hline
\end{tabular}

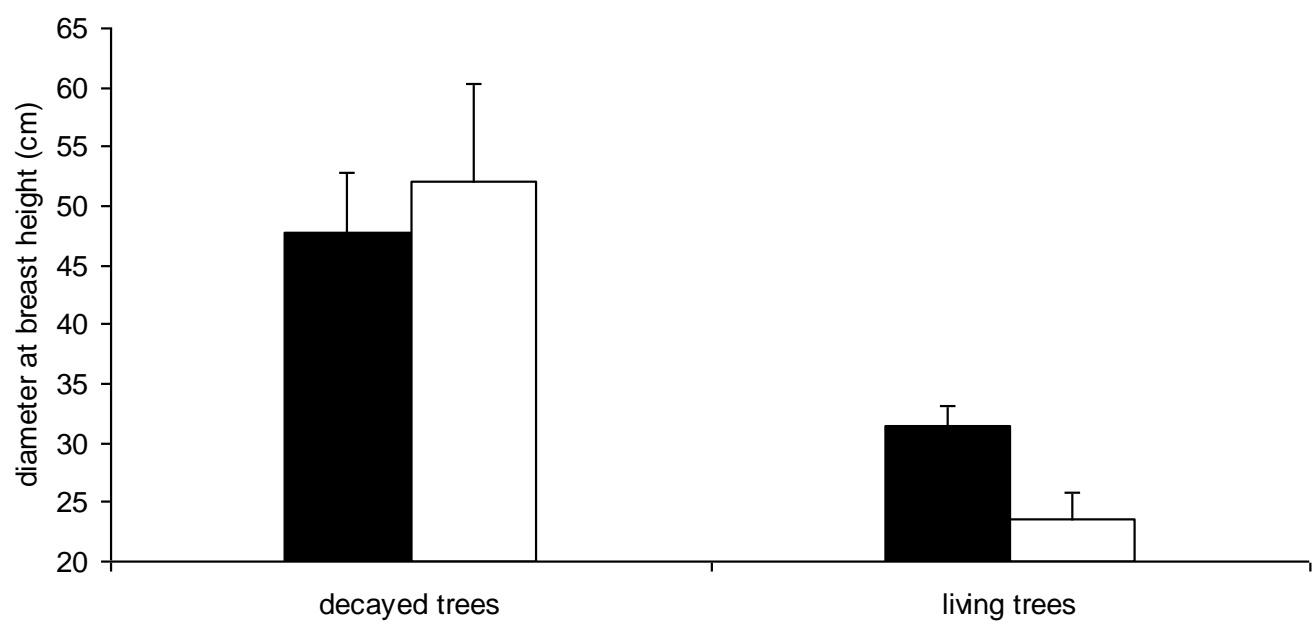

Fig. 2. Average (+SE) diameter at breast height of the trees used (black bars) and non-used (white bars) for foraging by 13 juvenile middle spotted woodpeckers. 


\subsection{Vegetation structure}

Home ranges had higher tree basal areas (median [range] $=15.3 \mathrm{~m}^{2} \mathrm{ha}^{-1}[7.56-$ 28.7] vs $\left.5.9 \mathrm{~m}^{2} \mathrm{ha}^{-1}[2.5-8.9], U=1.0, P<0.001\right)$, densities of trees $>22 \mathrm{~cm} \mathrm{DBH}$ (median [range] $=99.2$ trees ha $^{-1}[58.9-291.5]$ vs 11.7 trees ha ${ }^{-1}[0.0-50.0], U=0.0, P$ $<0.001$ ) and $>33 \mathrm{~cm} \mathrm{DBH}$ (median [range] = 35.6 trees ha $^{-1}[15.4-81.3$ ] vs 0.0 trees $\left.\mathrm{ha}^{-1}[0.0-8.3], U=0.0, P<0.001\right)$ than non-used areas, whereas the density of decayed trees did not differ significantly between areas (median [range] $=21.6$ trees ha ${ }^{-1}\left[3.5\right.$ - 79.0] vs 9.4 trees ha $\left.{ }^{-1}[0.0-79.2], U=23.0, P=0.241\right)$.

\section{DISCUSSION}

We provide, to our knowledge, the first study that examines habitat selection by juvenile birds at multiple hierarchically-nested spatial scales. Our results support the idea that foraging conditions may drive, at least partly, habitat use decisions by juvenile birds in the postfledging period. Old oak forest was the only positively selected habitat at the landscape and home range scales, and riverside forests were used as available, whereas young oak forests and pine plantations were avoided. Within oak and riverside forests, juveniles selected large deciduous trees for foraging. Pine plantations were not used for foraging and a juvenile was found only once in a small pine plantation surrounded by old oak forest. Previous studies have shown that old oak and riverside forests with large rough-bark deciduous trees provide higher foraging opportunities to adult middle spotted woodpeckers than young oak forests and pine plantations (Pasinelli \& Hegelbach 1997, Hertel 2003, Robles et al. 2007b). Moreover, home ranges had significantly higher densities of large trees selected for foraging by the birds (oaks, poplars and willows $>22$ and $>33 \mathrm{~cm} \mathrm{DBH}$ ) than the non-used areas, showing that juvenile woodpeckers actively chose good foraging habitats.

Habitat use by young birds may also be the result of the search for a future breeding site in the early postfledging period ("hypothesis of breeding territory selection"; Vega Rivera et al. 1998). Four of the 5 juveniles re-sighted the following spring were found in patches previously visited within the first three months after fledging, and the remaining individual bred in a patch close to other patches already 
visited (distances between the natal nest and the first breeding territory ranged from 0.9 to $4.8 \mathrm{~km}$ ), supporting the idea that juvenile woodpeckers might be searching for future breeding sites early after independence. Although more research is needed to shed light on this suggestion, these results match those of Eurasian nuthatches (Matthysen 1987) and some Parus species (Matthysen 1990), but contrast with recent studies on juvenile Neotropical migrant birds finding little support to this hypothesis (Lang et al. 2002, Keshner et al. 2004, White et al. 2005), which may be explained by the differences in life history traits among bird species. Nuthatches, woodpeckers and some Parus species are faithful to their territories year round, so the choice of an area where to settle is of great importance to juveniles because it provides foraging opportunities during the non-breeding season and will become a breeding territory in spring (Matthysen 1987, 1990, Pasinelli et al. 2001). Conversely, a better strategy for juvenile migrant birds may be to search for habitats with rich food resources where they can store fat and moult in the limited time available before migration (Vega Rivera et al. 1998, White et al. 2005).

Breeding adults and postfledging juveniles of migrant forest bird species often use different habitats, probably because of changes in food availability among habitats from breeding to postfledging seasons (Anders et al. 1998, Vega Rivera et al. 1998, White et al. 2005). However, in resident forest specialists such as the middle spotted woodpecker, the same habitat provides the most suitable foraging opportunities to breeding adults and postfledging juveniles. Indeed, juvenile woodpeckers mostly used (76\% of radio-locations) and positively selected old oak forest in the postfledging period, the same habitat as for the breeding adults (Robles et al. 2007b). From a conservation point of view, management actions of resident bird populations should focus on the improvement of the key habitat for both adults and juveniles, whereas the preservation of a mosaic of habitats for breeding, postbreeding and postfledging birds may be needed for migrant species (Anders et al. 1998, Vega Rivera et al. 1998, White et al. 2005).

Other factors may also influence juvenile habitat use decisions in the postfledging period. Because juveniles of many bird species, including the middle spotted woodpecker, undergo high predation rates during the first weeks after fledging 
(Anders et al. 1997, Naef-Daenzer et al. 2001, Götmark 2002, Cohen \& Lindell 2004, Kershner et al. 2004, Berkeley et al. 2007, Robles et al. 2007a), young may choose those habitats that provide the highest shelter from predators ("predator avoidance hypothesis"; White et al. 2005). Within our study area, pine plantations provide the most coverage and have considerably lower abundance and species richness of predators than old oak forests (unpubl.), so a higher selection of these plantations over old oak forests would be expected to avoid predators, which proved untrue.

Intraspecific competition is a selection pressure that may also drive habitat use decisions in birds (Lambin et al. 2001). All the young left the natal territory after independence, when young must compete for suitable foraging habitat with other conspecifics beyond the safety of the natal area. Supporting this hypothesis, some juveniles were chased by adult territorial woodpeckers after the beginning of dispersal. Nevertheless, information on aggressive interactions is limited, and more research, including home range overlap between juveniles and territorial birds, is needed to shed light on this hypothesis.

Within oak and riverside forests, juvenile woodpeckers selected large and decayed trees for foraging. Given that decayed trees have larger diameters than living trees, the selection for the former may be due to their larger diameter rather than to their condition. Supporting this hypothesis, we did not find significant differences in the density of decayed trees between home ranges and non-used areas. Nevertheless, because almost $25 \%$ of the foraging trees were dead trees, the role of dead wood for foraging juveniles may be relevant and deserves more research. Even though dead substrates seems to play a minor role for foraging middle spotted woodpeckers due to their search-and-probe strategy, dead wood is well known to provide refuge for larvae of many arthropods which may be potential prey for this woodpecker after their emergence (Pasinelli \& Hegelbach 1997, Pasinelli 2000).

An important step to establish appropriate management measures for conservation of avian populations is to identify suitable habitats for juvenile birds (Vega Rivera et al. 1998, White et al. 2005). Juvenile woodpeckers selected old oak forest. Riverside forest was used according to its availability, and large diameter poplars and willows were selected for foraging, indicating that riverside forests with large trees may also 
provide foraging opportunities to juvenile woodpeckers in the postfledging period. Conversely, young oak forests and pine plantations were avoided, suggesting that they are unsuitable habitats for juvenile woodpeckers. At a lower spatial scale, suitable densities of large trees in oak and riverside forests must be maintained to provide foraging opportunities to fledglings. As reference values, home ranges had a mean density of 141 tress $>22 \mathrm{~cm} \mathrm{DBH}$ and 44 trees $>33 \mathrm{~cm} \mathrm{DBH}$ per ha ${ }^{-1}$.

The importance of old oak forests in relation to other forested habitats is based on their higher densities of large oaks, which provide suitable foraging substrates to juveniles and breeding adults (Robles et al. 2007b). The loss of traditional sylvopastoral practices associated with rural abandonment in last decades threatens the persistence of old oak forests in Cantabrian Mountains (Robles et al. 2007b), with negative consequences on breeding and postfledging habitats for juvenile and adult middle spotted woodpeckers. The habitat improvement for this indicator and umbrella species (Angelstam et al. 2004, Roberge \& Angelstam 2006) based on the preservation of old oak forests with high densities of large trees would also favour other forest organisms such as birds (Camprodón 2001), carabids (Taboada et al. 2006a, b) or saproxylic beetles (Ranius \& Jansson 2000) and, in the case of Pyrenean oak dehesas, preserve a cultural heritage exclusive to Iberia (Luis-Calabuig et al. 1993, Blanco et al. 1997, Camprodón 2001).

\section{REFERENCES}

Aebischer, N. J., Robertson, P. A. \& Kenward, R. E. 1993. Compositional analysis of habitat use from animal radio-tracking data. Ecology 74: 1313-1325.

Anders, A. D., DeArborn, D. C., FAaborg, J. \& Thompson III, F. R. 1997. Juvenile survival in a population of Neotropical migrant birds. Conservation Biology 11: 698-707.

Anders, A. D., FAaborg, J. \& Thompson III, F. R. 1998. Postfledging dispersal, habitat use, and home-range size of juvenile wood thrushes. The Auk 115: 349-358.

ANGELSTAM, P. ET AL. 2004. Habitat modelling as a tool for landscape-scale conservation - a review of parameters for focal forest birds. Ecological Bulletin 51: 427-453. 
Berkeley, L. I., McCarty, J. P. \& Wolfenbarger, L. L. 2007. Postfledging survival and movement in dickcissels (Spiza americana): implications for habitat management and conservation. The Auk 124: 396-409.

Blanco, E., Casado, M. A., Costa, M., Escribano, R., Génova, M., Gómez, A., Gómez, F., Moreno, J. C., Morla, C., Regato, P. \& Sáinz, H. 1997. Los bosques ibéricos. Una interpretación geobotánica. Planeta, Barcelona.

CAMPRODÓN, J. 2001. Tratamientos forestales y conservación de la fauna vertebrada. In: Camprodón, J. \& Plana, E. (Eds.), Conservación de la biodiversidad y gestión forestal. Edicions Universitat de Barcelona, pp. 135-179.

Cohen, E. B. \& LindelL, C. A. 2004. Survival, habitat use, and movements of fledgling white-throated robins (Turdus assimilis) in a Costa Rican agricultural landscape. The Auk 121: 404-414.

Fuller, M. R., Millspaugh, J. J., Church, K. \& Kenward, R. 2005. Wildlife radiotelemetry. In: Braun, C. E. (Ed.), Techniques for wildlife investigations and management. The Wildlife Society, Bethesda, USA, pp. 377-417.

Ganey, J. L., Block, W. M., Dwyer, J. K., Strohmejer, B. E. \& Jenness, J. S. 1998. Dispersal movements and survival rates of juvenile Mexican spotted owls in northern Arizona. Wilson Bulletin 110: 206-217.

GötMARK, F. 2002. Predation by sparrowhawks favours early breeding and small broods in great tits. Oecologia 130: 25-32.

HeRTEL, F. 2003. Habitatnutzung und Nahrungserwerb von Buntspecht Picoides major, Mittlespecht Picoides medius und Kleiber Sitta europaea in bewirtschafteten und unbewirtschafteten Buchenwäldern des nordostdeutschen Tieflandes. Vogelwelt 124: $111-132$.

JACOBS, J. 1974. Quantitative measurement of food selection. Oecologia 14: 413-417.

JoHnson, D. H. 1980. The comparison of usage and availability measurements for evaluating resource preference. Ecology 61: 65-71.

JONES, J. 2001. Habitat selection studies in avian ecology: a critical review. The Auk 118: 557-562. 
KenWARd, R. E. \& Hodder, K. H. 1996. Ranges V. An analysis system for biological location data. ITE, Wareham, UK.

Kershner, E. L., Walk, J. W. \& WARneR, R. E. 2004. Postfledging movements and survival of juvenile eastern meadowlarks (Sturnella magna) in Illinois. The Auk 121: 11461154.

KORPIMÄKI, E. \& LAGERSTRÖM, M. 1988. Survival and natal dispersal of fledglings of Tengmalm's owl in relation to fluctuating food conditions and hatching date. Journal of Animal Ecology 57: 433-441.

Lambin, X., Aars, J. \& Piertney, S. B. 2001. Dispersal, intraspecific competition, kin competition and kin facilitation: a review of the empirical evidence. In: Clobert, J., Danchin, E., Dhondt, A. A. \& Nichols, J. D. (Eds.), Dispersal. Oxford University Press, New York, pp. 110-122.

Lang, J. D., Powell, L. A., Krementz, D. G. \& Conroy, M. J. 2002. Wood thrush movements and habitat use: effects of forest management for redcockaded woodpeckers. The Auk 119: 109-124.

LEBAN, F. 1999. Resource Selection for Windows. Version 1.00 (Beta 8.4 - May 28, 1999). <www.cnrhome.uidaho.edu/fishwild/Garton/tools >.

LUCK, G. 2002. The habitat requirements of the rufous treecreeper (Climacteris rufa). 1. Preferential habitat use demonstrated at multiple spatial scales. Biological Conservation 105: 383-394.

luis-Calabuig, E., Tárrega, R., Calvo, L., Díez, C., Marcos, E., Valbuena, L. \& Alonso, I. 1993. Análisis fisionómico de los ecosistemas de Quercus pyrenaica Willd. en la cuenca del Duero. Congreso Forestal Español. Lourizán, Pontevedra.

MATTHYSEN, E. 1987. Territory establishment of juvenile nuthatches after fledging. Ardea 75: 53-57.

MatThysen, E. 1990. Nonbreeding social organization in Parus. Current Ornithology 7: 210-249. 
Menzel, M. A., Menzel, J. M., Ford, W. M., Edwards, J. W., Carter, T. C., Churchill, J. B. \& KILGO, J. 2001. Home range and habitat use of male Rafinesque's big-eared bats (Corynorhinus rafinesquii). American Midland Naturalist 145: 402-408.

NAef-Daenzer, B., Widmer, F. \& Nuber, M. 2001. Differential post-fledging survival of great and coal tits in relation to their condition and fledging date. Journal of Animal Ecology 70: 730-738.

Onrubia, A., Robles, H., Salas, M., González-Quirós, P. \& Olea, P. P. 2004. Pico Mediano, Dendrocopos medius. In: Madroño, A., González, C. \& Atienza, J. C. (Eds.), Libro Rojo de las aves de España. Dirección General para la Biodiversidad-SEO/BirdLife, Madrid, pp. 304-307.

Overskaug, K., Bolstad, J. P., Sunde, P. \& Oien, I. J. 1999. Fledgling behaviour and survival in northern tawny owls. Condor 101: 169-174.

Pasinelli, G. \& HegelbaCH, J. 1997. Characteristics of tress preferred by foraging middle spotted woodpecker Dendrocopos medius in northern Switzerland. Ardea 85: 203209.

PASINELLI, G. 2000. Oaks (Quercus sp.) and only oaks? Relations between habitat structure and home range size of the middle spotted woodpecker (Dendrocopos medius). Biological Conservation 93: 227-235.

PASINELLI, G. 2003. Dendrocopos medius middle spotted woodpecker. BWP Update 5: 49-99.

Pasinelli, G., Hegelbach, J. \& Reyer, H. U. 2001. Spacing behavior of the middle spotted woodpeckers in central Europe. Journal of Wildlife Management 65: 432-441.

Pettersson, B. 1985. Extinction of an isolated population of the middle spotted woodpecker Dendrocopos medius (L.) in Sweden and its relation to general theories on extinction. Biological Conservation 32: 335-353.

Pinheiro, J. C. \& BAtes, D. M. 2000. Mixed-Effects models in S and S-Plus. Springer, New York. 
Porneluzi, P. A. \& FAABORG, J. 1999. Season-long fecundity, survival, and viability of ovenbirds in fragmented and unfragmented landscapes. Conservation Biology 13: 1151-1161.

RANIUS, T. \& JANSSON, N. 2000. The influence of forest regrowth, original canopy cover and tree size on saproxylic beetles associated with old oaks. Biological Conservation 95: 85-94.

Roberge, J. M. \& ANGelSTAM, P. 2006. Indicator species between resident forest birds - A cross-regional evaluation in northern Europe. Biological Conservation 130: 134-147.

Robles, H. \& OleA, P. P. 2003. Distribución y abundancia del pico mediano (Dendrocopos medius) en una población meridional de la Cordillera Cantábrica. Ardeola 50: 275280.

Robles, H., Ciudad, C., Vera, R. \& Baglione, V. 2007a. No effect of habitat fragmentation on post-fledging, first-year and adult survival in the middle spotted woodpecker. Ecography 30: 685-694.

Robles, H., Ciudad, C., Vera, R., Olea, P. P., Purroy, F. J. \& Matthysen, E. 2007b. Sylvopastoral management and conservation of the middle spotted woodpecker at the south-western edge of its distribution range. Forest Ecology and Management 242: $343-352$.

Robles, H., Ciudad, C., Vera, R., Olea, P. P. \& Matthysen, E. 2008. Demographic responses of middle spotted woodpeckers (Dendrocopos medius) to habitat fragmentation. The Auk 125: 131-139.

Rolstad, J., LøKEN, B. \& RolStAD, E. 2000. Habitat selection as a hierarchical spatial process: the green woodpecker at the northern edge of its distribution range. Oecologia 124: 116-129.

Rudolph, D. C., CONneR, R. N. \& SChAefer, R. R. 2002. Red-cockaded woodpecker foraging behaviour in relation to midstory vegetation. Wilson Bulletin 114: 235-242.

SPSS. 2005. SPSS for windows. SPSS, Chicago, IL.

SWENSON, J. E. 1993. The importance of alder to hazel grouse in Fennoscandian boreal forest: evidence from four levels of scale. Ecography 16: 37-46. 
TaboadA, A., Kofze, D. J., Salgado, J. M. \& TÁrRega, R. 2006a. The influence of habitat type on the distribution of carabid beetles in traditionally managed "dehesa" ecosystems in NW Spain. Entomologica Fennica 17: 284-295.

TaboadA, A., Kofze, D. J., TÁrrega, R. \& Salgado, J. M. 2006b. Traditional forest management: do carabid beetles respond to human-created vegetation structures in an oak mosaic landscape? Forest Ecology and Management 237: 436-449.

Vega Rivera, J. H., Rappole, J. H., McShea, W. J. \& haAs, C. A. 1998. Wood thrush postfledging movements and habitat use in northern Virginia. Condor 100: 69-78.

White, J. D., Gardali, T., Thompson III, F. R. \& FAaborG, J. 2005. Resource selection by juvenile Swainson's thrushes during the post-fledging period. Condor 107: 388-401.

Wiens, J. D., Noon, B. R. \& ReYnolds, R. T. 2006. Post-fledging survival of northern goshawks: the importance of prey abundance, weather, and dispersal. Ecological Applications 16: 406-418.

WORTON, B. J. 1987. A review of models of home range for animal movement. Ecological Modelling 38: 277-298. 


\section{CAPÍTULO IV - OCUPACIÓN, \\ COLONIZACIÓN Y EXTINCIÓN DE \\ LOS PARCHES DE HÁBITAT}
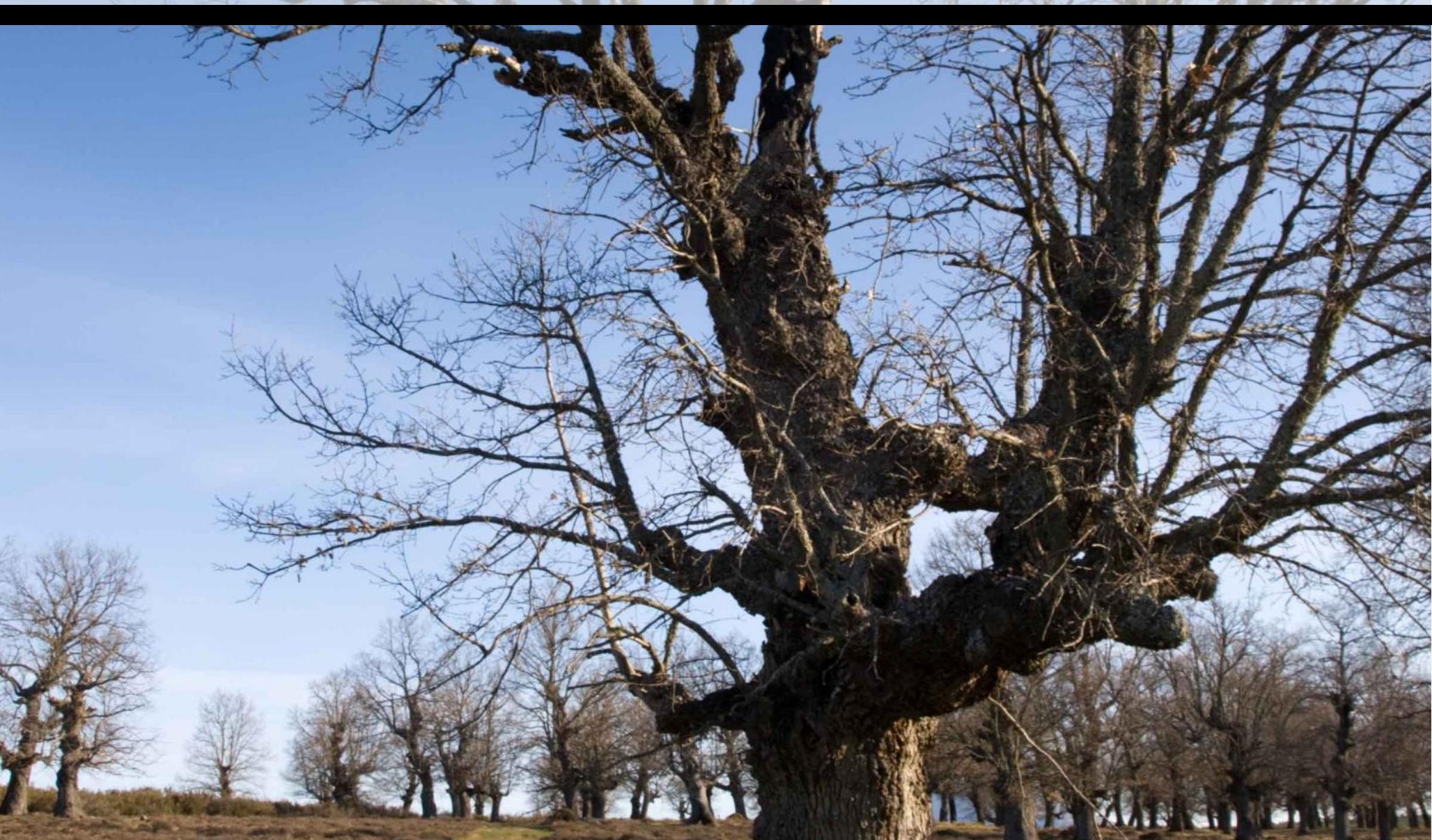


\title{
Testing assumptions of metapopulation models: the influence of habitat quality, population size, patch size and connectivity on occupancy and turnover rates of middle spotted woodpeckers
}

\begin{abstract}
Most models of metapopulation survival assume that colonization rates increase with patch connectivity, whereas extinction rates increase with declining patch size. We used an informationtheoretic approach to test these assumptions in the middle spotted woodpecker (Dendrocopos medius). Patch occupancy was monitored from 2000 to 2010 in the southern Cantabrian Mountains (NW Spain). According to a metapopulation structure, the number of occupied patches was rather stable over time because the extinction rate was balanced by recolonization. Patch extinction was mainly affected by population size but not by patch size, showing that, even if population size was influenced by patch size, the latter is not a good surrogate of population size for metapopulation models. Larger patches were more likely to be colonized, but connectivity had low influence, suggesting that habitat selection drives colonization. Because factors influencing turnover rates may vary depending on different conditions and/or species, the assumptions of metapopulation models should be specifically tested for each study system. Habitat quality variables had low influence on turnover rates. However, patch occupancy was positively related to the density of large oaks, which provides suitable foraging substrate to woodpeckers. Thus, the availability of foraging opportunities may be a critical factor influencing occupancy but, over a threshold in habitat quality, other factors influence turnover rates. Instead of improving patch connectivity, the increment of patch size and quality can favor occupancy and (re)colonization.
\end{abstract}

\section{EVALUANDO LAS ASUNCIONES DE LOS MODELOS METAPOBLACIONALES: LA INFLUENCIA DE LA CALIDAD DEL HÁBITAT, EL TAMAÑO POBLACIONAL, EL TAMAÑO DEL PARCHE Y LA CONECTIVIDAD SOBRE LA OCUPACIÓN Y LAS TASAS DE RENOVACIÓN DE LOS PICOS MEDIANOS}

RESUMEN.- La mayoría de los modelos de la supervivencia de las metapoblaciones asumen que las tasas de colonización se incrementan al aumentar la conectividad de los parches, mientras que las tasas de extinción se incrementan con la reducción del tamaño de los parches. Usamos un enfoque basado en la teoría de la información para probar estas asunciones en el pico mediano (Dendrocopos medius). Monitoreamos la ocupación de los parches de 2000 a 2010 en la vertiente sur de la Cordillera Cantábrica (NW España). De acuerdo a una estructura metapoblacional, el número de parches ocupados se mantuvo más bien estable a lo largo del tiempo debido a que la tasa de extinción fue equilibrada por las recolonizaciones. La extinción de los parches estuvo afectada principalmente por el tamaño poblacional pero no por el tamaño del parche, mostrando que, pese a que el tamaño poblacional estuvo influido por el tamaño del parche, este último no es un buen sustituto del tamaño poblacional para los modelos metapoblacionales. Los parches más grandes tuvieron más probabilidad de ser colonizados, pero la conectividad tuvo una baja influencia, sugiriendo que la selección del hábitat dirige la colonización. Puesto que los factores que influyen en las tasas de renovación pueden variar dependiendo de diferentes condiciones y/o especies, las asunciones de los modelos metapoblacionales deberían ser probadas específicamente para cada sistema de estudio. Las variables de calidad del hábitat tuvieron baja influencia en las tasas de renovación. Sin embargo, la ocupación de los parches estuvo positivamente relacionada con la densidad de robles grandes, los cuales proveen de sustrato adecuado de forrajeo a los picos. Por tanto, la disponibilidad de oportunidades de forrajeo puede ser un factor crítico para la ocupación pero, sobre un umbral de calidad del hábitat, otros factores influyen en las tasas de renovación. En lugar de mejorar la conectividad de los parches, el incremento del tamaño y la calidad de los parches pueden favorecer la ocupación y la (re)colonización. 


\section{INTRODUCTION}

After habitat fragmentation, species may occur in small and separated habitat patches where their survival can be seriously threatened (Lens et al. 2002, Groom et al. 2006, Lindenmayer \& Fischer 2006). The dynamics of these spatially discrete subpopulations have often been studied within a metapopulation framework (Hanki \& Gilpin 1997, Hanski 1999). Most models that assess the survival of metapopulations assume that the probability of colonization increases with patch connectivity, whereas extinction rate increases with reduction of habitat patch size. However, the few empirical studies that have tested such assumptions provide contrasting results. For example, some studies show that colonization rate increases with patch size but not with connectivity (Crooks et al. 2001, Franzén \& Nilsson 2010), or that extinction rate decreases with patch connectivity but not with patch size (Franken \& Hik 2004, Vögeli et al. 2010). Even fewer studies have incorporated measures of habitat quality to examine metapopulation dynamics, also providing contrasting results. Some studies indicate that the intrinsic quality of the habitat patch has as much (or even more) importance as patch size and connectivity on metapopulation dynamics (Fleishman et al. 2002, Franken \& Hik 2004, Franzén \& Nilsson 2010), whereas others show that landscape characteristics are more relevant (Vögeli et al. 2010). Therefore, more studies are needed to identify the most important factors influencing colonization and extinction rates.

Assessing the spatial organization of populations in fragmented habitats is crucial for their conservation (Mayer et al. 2009). Populations in fragmented habitats are often classified as metapopulations, but real systems rarely match metapopulation assumptions in the few studies where they have been tested (Harrison \& Taylor 1997, Mayer et al. 2009). In a metapopulation, habitat patches may support local breeding populations partly isolated from each other, so populations are subjected to extinction and recolonization processes. Recolonizations of extinct populations lead to a longer persistence of the entire metapopulation than local populations, which are subjected to high extinction risks (Levins 1970). Besides metapopulations, other spatial population structures have been described as the "patchy population model" and the "isolated populations model" (Mayer et al. 2009). Unlike a metapopulation, a patchy 
population is a single population formed by well-connected subpopulations subjected to low extinction risk (Harrison 1991). In the model of isolated populations, habitat patches hold completely isolated local populations that will not be recolonized after extinction (Frankham et al. 2002).

The middle spotted woodpecker (Dendrocopos medius) is a resident forest bird that has been shown to be sensitive to habitat loss, fragmentation and degradation (Pettersson 1985a, 1985b, Robles et al. 2007a, 2008, Ciudad et al. 2009). In an 11-year study (2000-2010), we assess the spatial population structure of middle spotted woodpeckers inhabiting fragmented habitats in the Cantabrian Mountains (Northwest Spain). Then, we examine the influence of habitat quality, population size, patch size and connectivity on patch occupancy and turnover (colonization and extinction) rates. Because the middle spotted woodpecker is an indicator of bird species richness and abundances in Palaearctic deciduous forests (Roberge \& Angelstam 2006), understanding the underlying ecological mechanisms of the variation in occupancy and turnover rates may have also implications for conservation of other European forest birds.

\section{METHODS}

\subsection{Study species and area}

The middle spotted woodpecker is a medium sized ( $\sim 55 \mathrm{~g})$ forest specialist bird associated with old rough-bark deciduous forests of the western Palaearctic (Pasinelli 2003). The social system is characterized by monogamy (Michalek \& Winkler 2001) and territoriality (Pasinelli et al. 2001). Both parents share breeding duties (Michalek \& Winkler 2001) and raise a single brood per year (Pasinelli 2003).

This study was conducted in a $\sim 750 \mathrm{~km}^{2}$ area in the Cantabrian Mountains (Northwest Spain, $42^{\circ} 44^{\prime} \mathrm{N}, 5^{\circ} 1^{\prime} \mathrm{W}, 900-1250 \mathrm{~m}$ a.s.I.). The Cantabrian population of middle spotted woodpecker is located at the south-western edge of its distribution range (Robles et al. 2007a). The study area represents the southern edge of the distribution of the middle spotted woodpecker in Spain, with no continuity in directions south, east and west, but the population continues to the north in the 
Cantabrian Mountains. This area comprises interspersed patches of forest, pastures, scrublands, cereal croplands, urban and rocky areas. Potential breeding habitats for the middle spotted woodpecker are old-growth deciduous oak forests mainly dominated by Quercus pyrenaica (Robles \& Olea 2003, Robles et al. 2007a), whereas heavily-disturbed young oak patches and other forested habitats (Pinus pinaster, $P$. sylvestris, Fagus sylvatica, Populus sp., Salix sp., Fraxinus sp., Q. rotundifolia) are avoided (Onrubia et al. 2004, Robles et al. 2007a). Postfledging juvenile woodpeckers select the same habitat as the breeding adults during dependence and dispersal periods (Ciudad et al. 2009). Overall, 101 habitat patches $\geq 0.1$ ha (mean size \pm SE $=$ $30.2 \pm 7.2 \mathrm{ha}$ ) were identified by aerial photographs verified in the fields, covering $\sim 4 \%$ of the study area.

\subsection{Field methods}

From 2000 to 2010, we recorded data on woodpecker occupancy by monitoring the 101 patches identified in the study area. We did not inspect three patches in 2000. In addition, we did not inspect one patch located at the northern edge of the study area in 2008-2010. We monitored habitat patches 3-6 times from the period of pair formation in February-early March until the beginning of egg-laying in early May, coinciding with the peak of intra-specific aggression (Robles et al. 2008). We played back "kweek" and rattle calls (see Pasinelli 2003) to find the territory owners as quickly as possible. Once the presence of woodpeckers was detected we stopped using the playback technique to avoid attracting birds from nearby territories (Kossenko \& Kaygorodova 2001). We followed the birds and noted their signs of activity (visual and auditive) and intra-specific interactions on 1:4000-1:10000 scale maps (Robles \& Olea 2003, Robles et al. 2008). Detection probability of woodpeckers in a single visit to the habitat patches was 0.962 , and nearly 1.00 when two visits were performed (Robles 2004). In 37 cases, we observed one to three woodpeckers in only one or two visits (of the first three visits) to some patches. We performed subsequent visits to confirm territorial settlement in these patches, but no birds were found despite intensive searches (up to 9 visits). Patches occupied temporally by these "transient" birds were considered as unoccupied by territorial birds (Robles \& Olea 2003, Robles et al. 2008). 
Besides, we preformed additional visits to some patches during the breeding season (early May-early July) to search for nests and to confirm territorial settlement of woodpeckers (Robles et al. 2008). All patches classified as occupied by territorial woodpeckers during the pre-breeding period were also occupied in the breeding season. By using these methods, we accurately estimated the number of territories (i.e. population size) in the habitat patches (Kosiński 2004, Robles et al. 2008). Because of time restrictions, we could not survey every year the entire area of two patches continuously occupied by woodpeckers during the study period, but at least $\sim 50 \%$ of their area was inspected each year. In years when the entire area was not surveyed, we calculated population size in these patches by extrapolation of the population density obtained in the surveyed area. Nevertheless, the number of territories in the surveyed areas was fairly constant across the years, indicating that we provided a good estimation of the population size in these two patches.

\subsection{Data analysis}

A patch was considered to be colonized if territorial woodpeckers were absent the previous spring and present the subsequent one. A patch was defined as becoming extinct if woodpeckers were present in the previous spring, but absent in the following one. Overall, 23 colonization and 16 extinction events were identified. Patches never occupied during this study $(n=72)$ were not included in colonization and extinction analyses. We tested the influence of several patch-related variables on patch occupancy, colonization and extinction by generalized linear mixed models (GLMM) with binomial error distributions and logistic link functions (occupied/colonized/extinct 1, unoccupied/non-colonized/non-extinct 0 ). In the analyses of colonization, we compared the characteristics of the patches colonized in a given year $(t)$ to those of the patches that remained unoccupied in two subsequent years ( $t-1$ and $t)$. In the extinction analyses, we compared the characteristics of the patches that became extinct in a given year $(t)$ to those of the patches that remained occupied in two

subsequent years ( $t-1$ and $t$ ). Patch size and connectivity (calculated with ArcGIS 9.2 from geo-referenced aerial photographs verified in the field; Ciudad et al. 2009) were 
fitted as fixed terms. We used the connectivity index defined by Hanski (1994) as follows:

$$
S_{i}=\Sigma_{j \neq i} \exp \left(-\alpha d_{i j}\right) N_{j}
$$

where $S_{i}$ is the connectivity for patch $i$ to other potential source populations $j$ (including all habitat patches occupied by woodpeckers within the study area and a 5$10 \mathrm{Km}$-wide zone around the north edge), $\alpha$ scales the effect of distance on dispersal (1/ $\alpha$ is the average dispersal distance), $d_{i j}$ is the distance from patch $i$ to $j$, and $N_{j}$ is the population size of the potential source population $j$. Thus, $S_{i}$ considers distances to all potential source populations and their population size, and is based on the dispersal ability of individuals (Moilanen \& Hanski 2001). Considering an average inter-patch dispersal of $6.5 \mathrm{~km}$ for juvenile woodpeckers (i.e. the main inter-patch dispersers; Chapter II) in this study area, $\alpha$ was estimated to be 0.154 . We obtained similar results when the distance to all patches, instead of the distance to occupied patches only, was considered in this connectivity index (i.e. connectivity of landscapes elements sensu Moilanen \& Hanski 2006). Besides, we obtained similar results when the distance to the nearest occupied patch was taken as a measure of connectivity. Two measures of the intrinsic habitat patch quality were fitted as fixed terms: i) the density of large oaks ( $\geq 37 \mathrm{~cm} \mathrm{DBH}$, diameter at $1.3 \mathrm{~m}$ above ground), which provides foraging opportunities to postfledging juveniles and breeding adults (Robles et al. 2007a, Ciudad et al. 2009), and ii) the density of potential nesting trees ( $\geq 22 \mathrm{~cm}$ DBH dead, decay and/or with holes, Robles et al. 2007a). The abundance of large oaks and potential nesting trees have been shown to be inversely related to home range sizes in the middle spotted woodpecker (Pasinelli 2000). We calculated tree densities by establishing a network of 0.04 ha circular plots $\geq 100 \mathrm{~m}$ apart in the patches (Robles et al. 2007a, 2008), where $\sim 27000$ trees were measured. In addition, patch population size was fitted as a fixed term in the extinction analyses, as the extinction risk is expected to increase in low populated patches (e.g. Franzén \& Nilsson 2010). Patch and year identities were fitted as random terms to control for multiple observations within the same patches and years in all the analyses. 
We also examined the variation in patch population size (the number of territories) and in the proportion of years where a patch was occupied ("regularity" hereafter). Population size was analyzed by GLMM with Poisson error distributions and logarithmic link functions. Patch identity and year were fitted as random terms. Patches were only considered for analyses in years when they were occupied (i.e. zeros were excluded from analyses). Regularity was analyzed by generalized linear models with binomial error distributions and logistic link functions, where the number of years a patch was occupied was modeled as the response term and the total number of years inspected as the binomial denominator. Patches never occupied were not included in regularity analyses. Similar to previous analyses, patch size and connectivity, besides the densities of large oaks and potential nesting trees, were fitted as fixed terms in both population size and regularity analyses. In addition, the maximum number of territories observed in a patch was fitted as a fixed term in regularity analyses.

We used an information-theoretic approach to assess which variables and models best depicted the data (Burnham \& Anderson 2002). We run a set of models for each analysis previously indicated. Every set of models contained all the possible combinations of the specific variables. Predictor variables for each analysis were weakly correlated (i.e. $r_{s}<|0.38|$ ), indicating that multicollinearity was not a problem in the analyses. Model selection followed Akaike's Information Criterion corrected for small sample sizes (AICC) and Akaike model weights (Burnham \& Anderson 2002, Johnson \& Omland 2004). Akaike model weights quantify the support of every model by the data, where higher weights indicate better explanatory power, being 1 the sum of all weights. Models with $\Delta \mathrm{AICc}<2$ compared to the model with smallest AICc (i.e. the "best model") are considered to be well supported by the data (Burnham \& Anderson 2002). Model-averaged parameter estimates and standard errors were calculated across the set of candidate models. We also calculated the relative importance of each variable by summing the weights over all the models containing such variable (Burnham \& Anderson 2002). All statistical analyses were performed in R 2.10.1 ( $R$ Development Core Team 2009). Prior to analyses, continuous variables were standardized to have zero mean and variance of one. 


\section{RESULTS}

\subsection{Spatial population structure}

On average, 18 patches $( \pm 0.8 \mathrm{SE}$, range $=15-24)$ were occupied by territorial woodpeckers in a given year. The number of occupied patches was rather stable across the years $\left(r_{s}=0.53, t=1.86, P=0.095, \mathrm{n}=11\right.$ years; Fig. 1$)$. Of 29 patches occupied at least one year, 11 were occupied every year, whereas the remaining 18 patches underwent (re)colonization and/or extinction events. The number of colonized patches was negatively correlated to the number of extinctions in a given year $\left(r_{s}=-0.77, t=-\right.$ 3.38, $P=0.010, \mathrm{n}=10 ;$ Fig. 2 ).

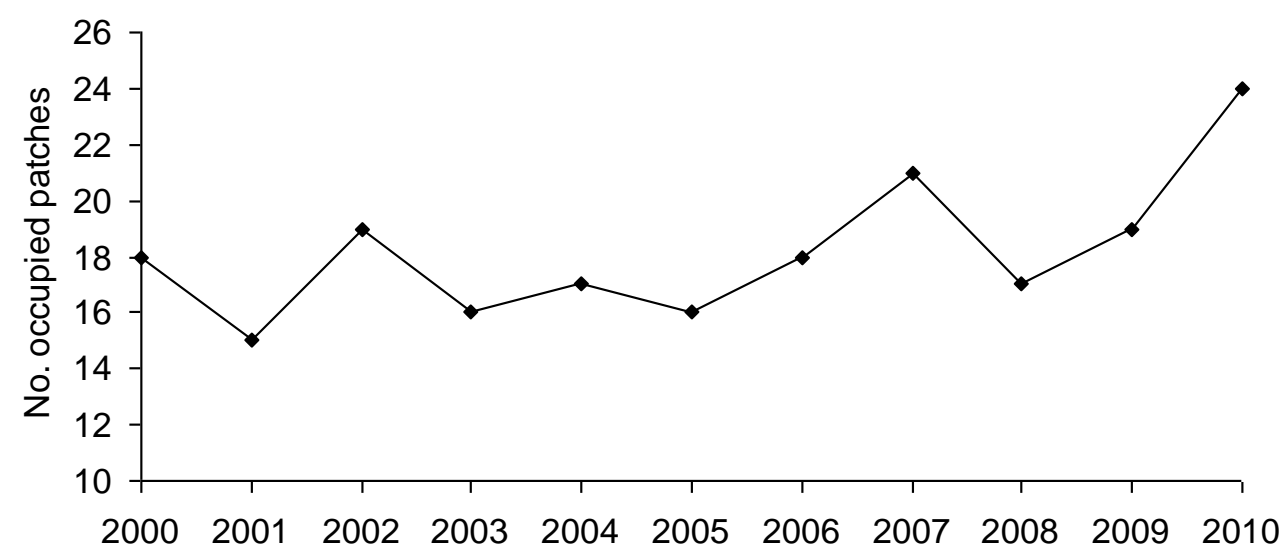

Fig. 1. Number of patches occupied by woodpeckers from 2000 to 2010.

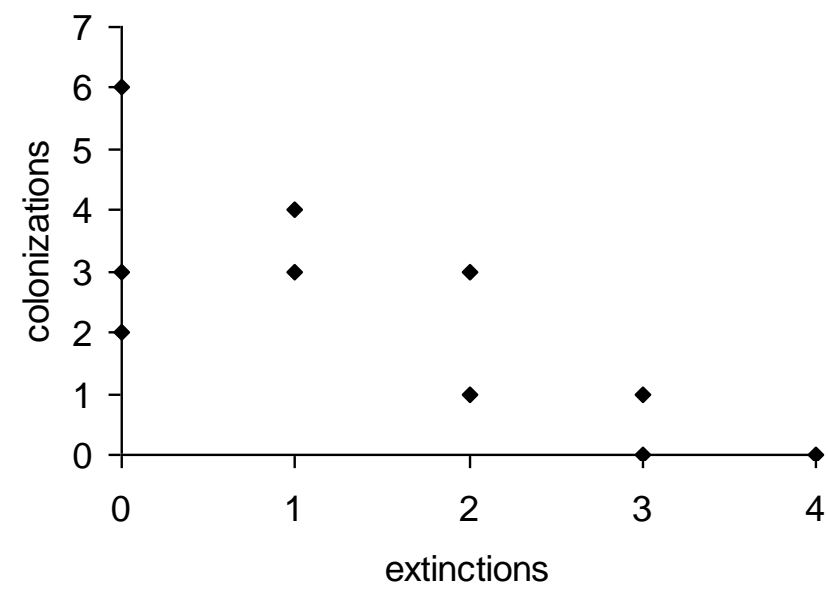

Fig. 2. Number of patches being colonized and becoming extinct in a given year. 


\subsection{Occupancy}

The best model included patch size and the density of large oaks as predictors of patch occupancy (Table 1). $\triangle \mathrm{AICC}$ of the intercept-only model was 53.4 (Akaike weight $=0.000$ ), indicating that the best model was well supported by the data. Both patch size and the density of large oaks had high relative importance values (Table 2). Larger patches with higher density of large oaks were more likely to be occupied in a given year, as indicated by their positive model-averaged parameter estimates (Table 2). Patch connectivity and the density of potential nesting trees had low relative importance values and small model-averaged parameter estimates compared to their associated standard errors, suggesting little influence of both variables on occupancy (Table 2).

\subsection{Population size}

Model selection yielded five high ranked models containing different combinations of all the four predictors (Table 1). The best model included patch size and connectivity as predictors. Patch size provided the highest contribution to the explanation of population size (i.e. the highest model-averaged parameter estimate and relative importance value, Table 2). Larger patches had higher population sizes. Patch connectivity had a lower relative importance value and a smaller model-averaged parameter estimate than its standard error (Table 2), indicating little influence on population size. The densities of large oaks and potential nesting trees had low relative importance values and considerably smaller model-averaged parameter estimates than their standard errors (Table 2), showing little influence of habitat quality related variables. 
Table 1. Model selection of analyses examining patch occupancy, population size, regularity in patch occupancy, patch extinction and patch colonization.

\begin{tabular}{llccccc}
\hline & Selected models & Deviance & $K$ & AlCc & $\Delta$ AlCc & Weight \\
\hline Occupancy & Patch size, Large oaks & 339.0 & 5 & 348.9 & 0.00 & 0.559 \\
& Patch size, Large oaks, Potential nesting tress & 338.0 & 6 & 350.5 & 1.58 & 0.254 \\
Population size & Patch size, Patch connectivity & 71.7 & 5 & 81.97 & 0.00 & 0.250 \\
& Patch size, Patch connectivity, Potential nesting trees & 70.1 & 6 & 82.51 & 0.54 & 0.191 \\
& Patch size, Patch connectivity, Large oaks & 70.8 & 6 & 83.25 & 1.28 & 0.132 \\
& Patch size, Large oaks & 73.0 & 5 & 83.36 & 1.39 & 0.125 \\
& Patch size & 75.3 & 4 & 83.48 & 1.51 & 0.118 \\
Regularity & Maximum population size, Patch size, Patch connectivity & 36.4 & 4 & 135.0 & 0.00 & 0.245 \\
& Maximum population size, Patch size & 39.3 & 3 & 135.3 & 0.22 & 0.219 \\
& Maximum population size & 43.4 & 2 & 136.9 & 1.82 & 0.099 \\
& Population size & 83.5 & 4 & 91.7 & 0.00 & 0.229 \\
& Population size, Patch size & 82.5 & 5 & 92.8 & 1.15 & 0.129 \\
& Population size, Potential nesting trees & 82.7 & 5 & 93.0 & 1.34 & 0.117 \\
& Population size, Patch connectivity & 83.2 & 5 & 93.6 & 1.89 & 0.089 \\
Colonization & Patch size & 103.9 & 4 & 112.3 & 0.00 & 0.319 \\
& Patch size, Large oaks & 103.3 & 5 & 113.9 & 1.62 & 0.142 \\
& Patch size, Potential nesting trees & 103.5 & 5 & 114.1 & 1.84 & 0.127 \\
\hline
\end{tabular}

* Models with $\triangle \mathrm{AICC}<2$ to the best model within the set of candidate models examined are indicated. Models are ranked according to their Akaike weight (Weight), higher weights indicating better explanatory power. $K$ : number of parameters, AICc: AIC corrected for small sample size, $\triangle \mathrm{AICc}$ : difference in AICc to the best model.

Table 2. Model-averaged parameter estimates and their associated standard errors (relative importance values in brackets) for variables included in the analyses of patch occupancy, population size, regularity in patch occupancy, patch extinction and patch colonization.

\begin{tabular}{llc}
\hline & Variables & Estimate \pm SE \\
\hline Occupancy & Large oaks & $2.540 \pm 0.491(1.00)$ \\
& Patch size & $2.990 \pm 1.110(0.99)$ \\
& Potential nesting trees & $-0.013 \pm 0.155(0.29)$ \\
& Patch connectivity & $0.078 \pm 0.150(0.18)$ \\
Population size & Patch size & $0.530 \pm 0.100(1.00)$ \\
& Patch connectivity & $0.102 \pm 0.103(0.64)$ \\
& Large oaks & $0.044 \pm 0.080(0.38)$ \\
Regularity & Potential nesting trees & $0.041 \pm 0.073(0.37)$ \\
& Maximum population size & $1.780 \pm 0.519(1.00)$ \\
& Patch connectivity & $-0.412 \pm 0.450(0.59)$ \\
& Patch size & $-0.498 \pm 0.692(0.46)$ \\
& Potential nesting trees & $0.003 \pm 0.086(0.21)$ \\
& Large oaks & $-0.025 \pm 0.120(0.21)$ \\
& Population size & $-7.880 \pm 3.360(1.00)$ \\
& Patch size & $0.650 \pm 1.250(0.34)$ \\
& Potential nesting trees & $0.098 \pm 0.192(0.34)$ \\
& Patch connectivity & $0.076 \pm 0.209(0.28)$ \\
& Large oaks & $-0.002 \pm 0.094(0.26)$ \\
& Patch size & $0.492 \pm 0.279(0.86)$ \\
& Potential nesting trees & $0.073 \pm 0.148(0.32)$ \\
& Large oaks & $0.044 \pm 0.113(0.28)$ \\
& Patch connectivity & $0.022 \pm 0.103(0.27)$ \\
\hline
\end{tabular}




\subsection{Regularity}

The analyses of regularity yielded three high ranked models (Table 1). Maximum population size was included in all high ranked models and had the highest relative importance value (Tables 1 and 2). Patches with higher population sizes were more likely to be continuously occupied over years. Besides maximum population size, patch connectivity was included in the best model, but its small model-averaged parameter estimate compared to the associate standard error suggests a low influence of connectivity (Tables 1 and 2). Patch size, and the densities of large oaks and potential nesting trees had low relative importance values and small parameter estimates compared to their standard errors, indicating low influence of these variables (Table 2).

\subsection{Extinction}

The best model included population size as predictor of patch extinction (Table 1). $\triangle \mathrm{AICC}$ of the intercept-only model was 15.0 (Akaike weight $=0.000$ ), indicating that the best model was well supported by the data. High populated patches were less likely to become extinct, as indicated by the high relative importance value and the negative model-averaged parameter estimate (Table 2). Patches that held $\leq 2$ territories were the most prone to extinction $(20.3 \%$ and $3.1 \%$ of patches with one and two territories became extinct, respectively); whereas all patches with $\geq 3$ territories persisted in subsequent years. Patch size and connectivity, in addition to the densities of large oaks and potential nesting trees, had low relative importance values and small parameter estimates compared to their associated standard errors (Table 2), indicating low influence of all these four variables on patch extinction.

\subsection{Colonization}

The best model of patch colonization included patch size as the only predictor (Table 1). This model was almost eight times more likely to be the best model than the intercept-only model (Akaike weight $=0.040, \Delta \mathrm{AICC}=4.14)$, indicating that the best model was well supported by the data. Larger patches were more likely to be 
colonized in a given year, as indicated by the positive model-averaged parameter estimate of patch size (Table 2). The densities of large oaks and potential nesting trees, besides patch connectivity, had low relative importance values and smaller modelaveraged parameter estimates than their associated standard errors (Table 2), showing little influence on patch colonization.

\section{DISCUSSION}

\subsection{Spatial population structure}

Our results indicate some similarities with both metapopulation and patchy population models, but the presence of recolonizations rules out the isolated populations' model (Frankham et al. 2002). According to a metapopulation structure, the extinction rate was balanced by recolonization, so the number of occupied patches was rather stable over time (Hanski \& Gaggiotti 2004, Driscoll 2007). On the other hand, high inter-patch dispersal of woodpeckers in this study area (Chapter II) brings some support for the patchy population model (Discroll 2007, Mayer et al. 2009). Indeed, some inter-patch dispersers successfully bred after settlement, but genetic analyses are needed to assess if effective dispersal leads to genetic homogenization of the whole population. Nevertheless, the presence of local extinctions and subsequent recolonizations is rather in accordance with a metapopulation model than with a patchy population structure where local subpopulations are not subjected to high extinction risks (Discroll 2007, Mayer et al. 2009). Recolonizations of extinct populations lead to a longer persistence of the entire metapopulation than small local populations, which are probably subjected to high extinction risks. According to these results, we tentatively conclude that our system represents an intermediate step between metapopulation and patchy population models, with more similarities with the metapopulation model. We believe this is probably the situation of many populations inhabiting fragmented habitats, as models of spatial population structure represent steps of a gradient in the connectivity among patches (Discroll 2007, Mayer et al. 2009). 


\subsection{What does influence occupancy and turnover rates?}

Most metapopulation models assume that colonization rates increase with patch connectivity and extinction rates with declining habitat patch size. Our results, however, did not support such assumptions. Patch extinction was mainly affected by population size but not by patch size, showing that, even if population size was largely influenced by patch size, the use of patch size as a surrogate of population size may lead to unreliable results when metapopulation dynamics are assessed (see also Pellet et al. 2007, Franzén \& Nilsson 2010). On the other hand, patch colonization was influenced by patch size, but connectivity had low influence, suggesting that habitat selection rather than a variation in the connectivity drives colonization of habitat patches. Indeed, Pellet et al. (2007) showed that connectivity is a poor predictor of colonization events. Because factors influencing colonization and extinction rates may vary depending on different conditions and/or species, we suggest that the assumptions of metapopulation models should be specifically tested for each study system.

Low populated patches were more prone to extinction and less frequently occupied across the years (i.e. lower regularity), suggesting that demographic stochasticity may drive extinctions and persistence of small populations. Some field observations support this hypothesis. In one case, a patch was colonized by a second-year male that bred successfully in two consecutive breeding seasons, but its mate disappeared the third breeding season just during the egg-laying period. The following week this male moved to a different patch $7 \mathrm{Km}$ apart, where it settled in a breeding territory for two years. Thus, demographic stochasticity (disappearance of females) led to dispersal of the mate and, ultimately, to patch extinction.

Our results also suggest a substantial influence of environmental stochasticity on turnover rates. The number of colonizations and extinctions were negatively correlated, being colonization rates higher than extinctions in good years and viceversa. This inter-annual variation may be driven by weather conditions, which influence reproduction and survival of woodpeckers. Indeed, breeding density is correlated to winter (Pettersson 1985a, Wesolowski \& Tomialojc 1997) or spring (Michalek et al. 2001) temperatures in some middle spotted woodpecker populations, 
whereas breeding success is negatively related to the amount of rain during the nesting period (Pasinelli 2001, Kosiński \& Ksit 2006, Kossenko \& Kaygorodova 2007), suggesting that the variation in weather conditions may drive, at least partly, population dynamics.

Contrary to most previous studies (e.g. Pettersson 1985b, Thomas \& Jones 1993, Van Langevelde 2000, Hames et al. 2001, Thomas et al. 2001, Franken \& Hik 2004, Vögeli et al. 2010; but see Pellet et al. 2007), patch connectivity (i.e. the inverse of isolation) had low influence on patch occupancy, population size, regularity and turnover rates. Among-studies differences may arise because habitat quality, population size, patch size and connectivity are often correlated variables, so the variation in connectivity may indicate also changes in other potentially influencing parameters. This is particularly relevant when analyses show a strong influence of patch connectivity and other correlated variables, making more difficult to determine which variable is actually responsible for the observed effect. However, in this study patch connectivity was weakly correlated to other variables. Alternatively, connectivity (or isolation) may be an important predictor of occupancy and turnover rates in declining populations subjected to severe isolation, but not in equilibrated (meta)populations inhabiting networks of well-connected habitat patches. For example, habitat isolation has been found to influence occupancy and regularity in a declining and highly isolated population of middle spotted woodpeckers in Sweden, contrary to our balanced (meta)population (see below) where inter-patch dispersal is frequent (Chapter II). Nevertheless, those results must be interpreted with caution because, in Sweden, habitat isolation was strongly correlated to oak habitat area (Pettersson 1985b).

Recent studies have found that the intrinsic habitat quality has a strong influence on turnover rates in several organisms such as the solitary bee (Andrena hattorfiana) (Franzén \& Nilsson 2010), the butterfly Speyeria Nokomis (Fleishman et al. 2002) and the collared pika (Ochotona collaris) (Franken \& Hik 2004). Our results did not support this hypothesis in the middle spotted woodpecker, as habitat quality variables had low influence on extinction and colonization rates, population size or regularity. However, patch occupancy was positively related to the density of large oaks, which provides 
suitable foraging substrate to postfledging juveniles and breeding adults (Robles et al. 2007a, Ciudad et al. 2009, Chapter III). This suggests that the availability of foraging opportunities provided by large oaks is a critical factor influencing patch occupancy but, over a threshold of quality in foraging habitat, other factors such as population size or patch size influence turnover rates.

Larger patches were more likely to be occupied and colonized. Some patches were too small ( $\leq 5 \mathrm{ha}$ ) to allow the establishment of home ranges (Pasinelli et al. 2001) and therefore woodpecker occupancy, but all patches used for colonization analyses were occupied at least one year, indicating that they held woodpecker home ranges. Patch size does not influence breeding performance and survival of woodpeckers in the Cantabrian Mountains (Robles et al. 2007b, 2008, Chapter I), suggesting that low fitness prospect in small patches may not be the mechanism underlying the reduced colonization rates. Nevertheless, smaller patches used for colonization analyses are expected to hold lower total amount of resources such as food or nest sites than larger patches (i.e. the "resource concentration hypothesis"; Root 1973), so small patches might be judged to be of low quality by dispersers. If this hypothesis proved true, habitat selection may drive the recolonization of empty patches in our study system. Alternatively, larger patches are more likely to be found by chance, and hence colonized by dispersers, than smaller ones.

The density of potential nesting trees had low influence on patch occupancy, population size, regularity and turnover rates. This may arise because the availability of nest sites is not a limiting factor of woodpecker populations in the Cantabrian Mountains, where a high amount of large decayed trees suitable for nesting are accessible to woodpeckers in old-growth oak patches. Besides, as primary cavity nesters, woodpeckers are expected to be less negatively influenced by the scarcity of nesting sites than secondary cavity-nesting and open-nesting organisms in forested habitats. 


\subsection{Conservation implications}

Only a small proportion of old oak patches (15-24\%) was occupied each year. Increasing patch size and large oak density $(\mathrm{DBH} \geq 37 \mathrm{~cm})$ in the patches can favor occupancy and (re)colonization of local patches. As reference values, average size of the patches occupied and colonized by woodpeckers was 84 ha and 35 ha, respectively, whereas average density of large oaks in occupied patches was 55 trees/ha. Small habitat patches may be enlarged by selective cutting in unsuitable small-diameter oak forest of the adjacent matrix, allowing the growth of the remaining trees to create large oak forest suitable for breeding adults and postfledging juvenile middle spotted woodpeckers (Robles et al. 2007a, Ciudad et al. 2009, Chapter III). However, improving the connectivity of local patches may be an unsuccessful strategy in this well-connected area where isolation has low influence on dispersal (Chapter II), occupancy and turnover rates. Further, the improvement of connectivity in populations subjected to negative effects of patch isolation may not suffice if other factors such as patch size or quality also influence (meta)population dynamics.

\section{REFERENCES}

BURNhAM, K. P. \& ANDERSON, D. R. 2002. Model selection and multi-model inference: $a$ practical information-theoretic approach. Springer, New York.

Ciudad, C., Robles, H. \& Matthysen, E. 2009. Postfledging habitat selection of juvenile middle spotted woodpeckers: a multi-scale approach. Ecography 32: 676-682.

Crooks, K. R., SuArez, A. V., Bolger, D. T. \& Soulé, M. E. 2001. Extinction and colonization of birds on habitat islands. Conservation Biology 15: 159-172.

FAHRIG, L. 2003. Effects of habitat fragmentation on biodiversity. Annual Review of Ecology, Evolution and Systematics 34: 487-515.

Fleishman, E., Ray, C., SuÖgren-Gulve, P., Boggs, C. L. \& Murphy, D. D. 2002. Assessing the roles of patch quality, area, and isolation in predicting metapopulation dynamics. Conservation Biology 16: 706-716. 
FRANKEN, R. J. \& HIK, D. S. 2004. Influence of habitat quality, patch size and connectivity on colonization and extinction dynamics of collared pikas Ochotona collaris. Journal of Animal Ecology 73: 889-896.

Frankham, R., Ballou, J. D. \& Briscoe, D. A. 2002. Introduction to Conservation Genetics. Cambridge University Press, Cambridge.

Franzén, M. \& NiLSSON, S. G. 2010. Both population size and patch quality affect local extinctions and colonizations. Proceedings of the Royal Society of London B 277: 7985.

Groom, M. J., Meffe, G. K. \& Carroll, C. R. 2006. Principles of Conservation Biology, 3rd edition. Sinauer, Sunderland, Massachusetts.

Hames, R. S., Rosenberg, K. V., Lowe, J. D. \& Dhondt, A. A. 2001. Site reoccupation in fragmented landscapes: testing predictions of metapopulation theory. Journal of Animal Ecology 70: 182-190.

HANSKI, I. 1994. A practical model of metapopulation dynamics. Journal of Animal Ecology 63: 151-162.

HANSKI, I. 1999. Metapopulation Ecology. Oxford University Press, New York.

HANSKI, I. \& GILPIN, M. E. 1997. Metapopulation biology: ecology, genetics and evolution. Academic Press, San Diego.

HARRISON, S. 1991. Local extinction in a metapopulation context: an empirical evaluation. Biological Journal of the Linnean Society 42: 73-88.

HARRISON, S. \& TAYLOR, A. D. 1997. Empirical evidence for metapopulation dynamics. In Hanski, I. \& Gilpin, M. E. (Eds.), Metapopulation biology: ecology, genetics and evolution. Academic Press, San Diego, pp. 27-42.

JoHnSON, J. B. \& OMLAND, K. S. 2004. Model selection in ecology and evolution. Trends in Ecology and Evolution 19: 101-108.

KOSIŃSKI, Z. \& KSIT, P. 2006. Comparative reproductive biology of middle spotted woodpeckers Dendrocopos medius and great spotted woodpeckers D. major in a riverine forest. Bird Study 53: 237-246. 
Kossenko, S. M. \& KAYgorodova, E. Y. 2001. Effect of habitat fragmentation on distribution, density and breeding performance of the middle spotted woodpecker Dendrocopos medius in the Nerussa-Desna woodland. Entomological Review 81: S161-S166.

Kossenko, S. M. \& KAYgorodova, E. Y. 2007. Reproduction of the middle spotted woodpecker Dendrocopos medius in the Nerussa-Desna woodland, SW Russia, with particular reference to habitat fragmentation, weather conditions and food supply. Ardea 95: 177-189.

Lens, L., Van Dongen, S., Norris, K., Guitiru, M. \& Matthysen, E. 2002. Avian persistence in fragmented rainforest. Science 298: 1236-1238.

LEVINS, R. A. 1970. Extinctions. In: Gerstenhaber, M. (Ed.), Some mathematical problems in biology. American Mathematical Society, Providence, Rhode Island, USA, pp. 77107.

LINDENMAYER, D. B. \& FISCHER, J. 2006. Habitat fragmentation and landscape change: an ecological and conservation synthesis. Island Press, Washington.

Mayer, C., SchiegG, K. \& Pasinelli, G. 2009. Patchy population structure in a shortdistance migrant: evidence from genetic and demographic data. Molecular Ecology 18: $2353-2364$.

MiCHALEK, K. G. \& WINKLER, H. 2001. Parental care and parentage in monogamous great spotted woodpeckers (Picoides major) and middle spotted woodpeckers ( $P$. medius). Behaviour 138: 1259-1285.

Michalek, K. G., Auer, J. A., Großberger, H., Schmalzer, A. \& Winkler, H. 2001. Die einflüsse von lebensraum, witterung und waldweristschaftung auf die brutdichte bon bunt- und mittlespecht (Picoides major und $P$. medius) in wiererwald. Abhandlungen und Berichte aus den Museum Heineanum 5: 31-58.

MoILANEN, A. \& HANSKI, I. 2001. On the use of connectivity measures in spatial ecology. Oikos 95: 147-151. 
Mollanen, A. \& HANSKI, I. 2006. Connectivity and metapopulation dynamics in highly fragmented landscapes. In: Crooks, K. R. \& Sanjayan, M. (Eds.), Connectivity Conservation. Cambridge University Press, Cambridge, pp. 44-71.

MüLlER, W. 1982. Die besiedlung der eichenwälder in Kanton Zürich durch den mittelspechts Dendrocopos medius. Der Ornithologische Beobachter 79: 105-119.

Onrubia, A., Robles, H., Salas, M., González-Quirós, P. \& Olea, P. P. 2004. Pico mediano, Dendrocopos medius. In: Madroño, A., González, C. \& Atienza, J. C. (Eds.), Libro Rojo de las aves de España. Dirección General para la Biodiversidad-SEO/BirdLife, Madrid, pp. 304-307.

PASINelLI, G. 2000. Oaks (Quercus sp.) and only oaks? Relations between habitat structure and home range size of the middle spotted woodpecker (Dendrocopos medius). Biological Conservation 93: 227-235.

PAsInelLI, G. 2001. Breeding performance of the middle spotted woodpecker Dendrocopos medius in relation to weather and territory quality. Ardea 89: 353-361.

PASINELLI, G. 2003. Dendrocopos medius middle spotted woodpecker. BWP Update 5: 49-99.

Pasinelli, G., Hegelbach, J. \& Reyer, H. U. 2001. Spacing behavior of the middle spotted woodpeckers in central Europe. Journal of Wildlife Management 65: 432-441.

Pellet, J., Fleishman, E., Dobkin, D. S., Gander, A. \& Murphy, D. D. 2007. An empirical evaluation of the area and isolation paradigm of metapopulation dynamics. Biological Conservation 136: 483-495.

Pettersson, B. 1985a. Extinction of an isolated population of the middle spotted woodpecker Dendrocopos medius (L.) in Sweden and its relation to general theories on extinction. Biological Conservation 32: 335-353.

Pettersson, B. 1985b. Relative importance of habitat area, isolation and quality for the occurrence of middle spotted woodpecker Dendrocopos medius (L.) in Sweden. Holarctic Ecology 8: 53-58.

R Development Core Team. 2009. R: A Language and Environment for Statistical Computing. R Foundation for Statistical Computing, Vienna, Austria. 
Roberge, J. M. \& ANGelStAM, P. 2006. Indicator species between resident forest birds - A cross-regional evaluation in northern Europe. Biological Conservation 130: 134-147.

RoBles, H. \& OleA, P. P. 2003. Distribución y abundancia del pico mediano (Dendrocopos medius) en una población meridional de la Cordillera Cantábrica. Ardeola 50: 275280.

Robles, H., Ciudad, C., Vera, R., Olea, P. P., Purroy, F. J. \& Matthysen, E. 2007a. Sylvopastoral management and conservation of the middle spotted woodpecker at the south-western edge of its distribution range. Forest Ecology and Management 242: $343-352$.

Robles, H., Ciudad, C., Vera, R. \& Baglione, V. 2007b. No effect of habitat fragmentation on post-fledging, first-year and adult survival in the middle spotted woodpecker. Ecography 30: 685-694.

Robles, H., Ciudad, C., Vera, R., Olea, P. P. \& Matthysen, E. 2008. Demographic responses of middle spotted woodpeckers (Dendrocopos medius) to habitat fragmentation. The Auk 125: 131-139.

Root, R. B. 1973. Organization of a plant-arthropod association in simple and diverse habitats: the fauna of collards (Brassica oleraceae). Ecological Monographs 45: 95120.

THOMAS, C. D. \& JONES, T. M. 1993. Partial recovery of a skipper butterfly (Hesperia comma) from population refuges: lessons for conservation in a fragmented landscape. Journal of Animal Ecology 62: 472-481.

Thomas, J. A., Bourn, N. A. D., Clarke, R. T., Stewart, K. E., Simcox, D. J., Pearman, G. S., CURTIS, R. \& GOODGER, B. 2001 The quality and isolation of habitat patches both determine where butterflies persist in fragmented landscapes. Proceedings of the Royal Society of London Series B 268: 1791-1796.

VAN LANGeVelde, F. 2000. Scale of habitat connectivity and colonization in fragmented nuthatch populations. Ecography 23: 614-622. 
Vögeli, M., Serrano, D., Pacios, F. \& Tella, J. L. 2010. The relative importance of patch habitat quality and landscape attributes on a declining steppe-bird metapopulation. Biological Conservation 143: 1057-1067.

WesoloWski, T. \& TOMIALOJC, L. 1997. Breeding bird dynamics in primaeval temperate forest: long-term trends in Bialowieza National Park (Poland). Ecography 20: 432453. 


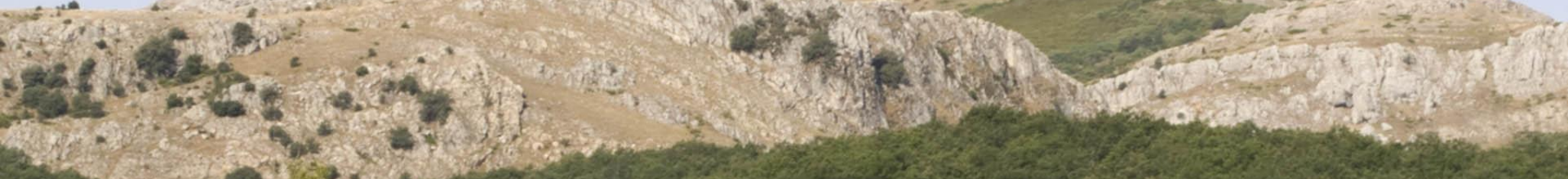

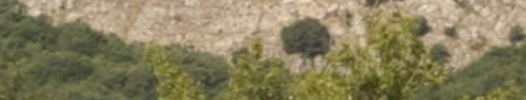

\section{DISCUSIÓN GENERAL}

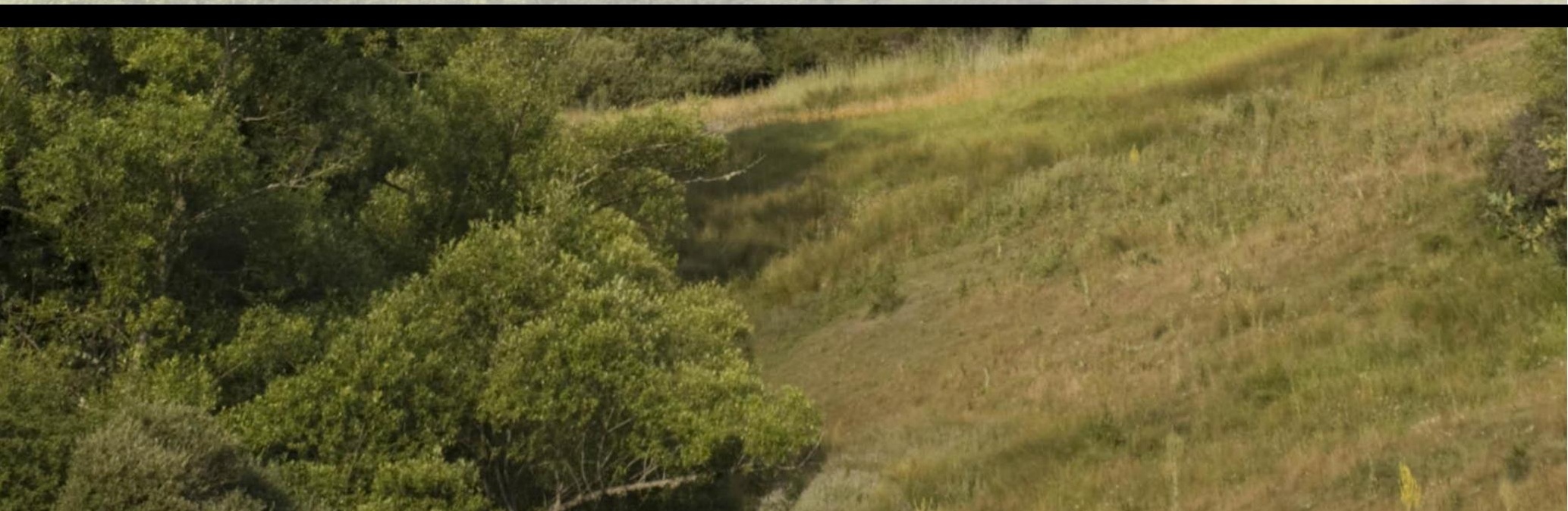




\section{DISCUSIÓN GENERAL}

La presente tesis ha abordado el estudio de los efectos de la fragmentación, pérdida y alteración del hábitat en distintas etapas y procesos vitales de un ave especialista de bosques caducifolios maduros: el pico mediano. En este apartado se pretende discutir los principales resultados obtenidos en los capítulos anteriores para incrementar el conocimiento de los efectos de estos procesos espaciales sobre el funcionamiento de las poblaciones de aves forestales. En base a estos resultados, se proponen medidas de gestión para la conservación del pico mediano y de su hábitat. Por último, se establecen líneas potenciales de investigación para el futuro.

\section{Efectos de la fragmentación, pérdida y alteración del hábitat del pico mediano}

La fragmentación, pérdida y alteración antropogénica de los hábitats forestales son una seria amenaza para la persistencia de numerosas especies de aves (Burke $\&$ Nol 1998, Dale 2001, Lens et al. 2002). La fragmentación y pérdida de hábitat llevan a una reducción del tamaño de los parches de hábitat que permanecen en el paisaje y al incremento del aislamiento (distanciamiento) entre ellos (Fahrig 2003). Estas dos repercusiones en la estructura y composición espacial de los parches pueden tener consecuencias muy negativas sobre las poblaciones de aves (Wilcox \& Murphy 1985, Murcia 1995, Zanette et al. 2000, Cooper \& Walters 2002, Luck 2003). Independientemente de los efectos de la fragmentación y pérdida de hábitat, la alteración del hábitat puede incrementar los niveles de estrés (ej. estrés trófico) sobre las aves, de tal manera que una vez superado cierto umbral de estrés su persistencia se ve seriamente comprometida (Lens et al. 2002). Las consecuencias de todos estos procesos espaciales sobre la población de pico mediano se describen a continuación.

\section{Efectos de la fragmentación y pérdida del hábitat}

En el caso de la población de pico mediano objeto de estudio, la reducción del tamaño de los parches de hábitat tuvo un fuerte efecto negativo sobre la probabilidad de ocupación y colonización de los parches, su tamaño poblacional (número de 
territorios) y el éxito de emparejamiento de los machos territoriales (Tabla 1). Esto sugiere que la pérdida de hábitat asociada a procesos de fragmentación puede tener serias consecuencias para la persistencia del pico mediano en la Cordillera Cantábrica, donde la fragmentación y pérdida de hábitat por causas tanto antropogénicas como naturales es la tónica general.

El efecto del tamaño de los parches de hábitat sobre la ocupación puede deberse a que algunos parches son demasiado pequeños para mantener territorios de pico mediano. Sin embargo, una vez que los parches ofrecieron un tamaño suficiente para poder ser ocupados, los parches más pequeños tuvieron menor probabilidad de ser colonizados (Capítulo IV). Este efecto no se debe a unas bajas expectativas de supervivencia o reproducción de los picos en los parches pequeños, ya que el tamaño de los parches no afectó a estos parámetros relacionados con la eficacia biológica (Tabla 1). Los parches grandes podrían ser considerados por los picos dispersantes como de alta calidad ya que albergan una mayor cantidad total de recursos críticos (ej. alimento o sitios de cría) para la especie ("resource concentration hypothesis"; Root 1973, Capítulo IV). No obstante, a nivel individual los picos no prefirieron asentarse en parches de mayor tamaño (Capítulo II), sugiriendo que estos parches no fueron evaluados por las aves como de mayor calidad que los parches pequeños. Otra posibilidad es que los parches grandes podrían ser más fáciles de encontrar por los dispersantes en ausencia de otras claves indicadoras de la calidad de los parches (ej. presencia de coespecíficos; Capítulo II).

El efecto del tamaño de los parches en el éxito de emparejamiento de los machos territoriales puede no implicar una relación causal, ya que el tamaño de los parches estuvo correlacionado con el aislamiento y el número de territorios en los mismos, y estas tres variables aparentemente influyeron en el emparejamiento de los machos (Robles et al. 2008, Capítulo I). No obstante, el tamaño y el aislamiento de los parches no tuvo una fuerte influencia en el asentamiento (inmigración) de las hembras dispersantes (Capítulo II; Tabla 1), sugiriendo que estos factores no explican el bajo éxito de emparejamiento de los machos en los parches pequeños y aislados. En apoyo de esta hipótesis, algunas hembras visitaron a machos no emparejados temporalmente, lo que muestra que una disrupción en la conectividad asociada con la 
mayor dificultad para encontrar parches pequeños y aislados probablemente no explica la presencia de machos sin pareja en estos parches (Robles et al. 2008, Capítulo I). Además, el sex-ratio de los volantones no difiere de una proporción 1:1 y no está relacionado con el tamaño o aislamiento de los parches, la mortalidad no varía entre sexos y la supervivencia no se ve fuertemente afectada por la fragmentación (Robles et al. 2007b), por lo que es poco probable que el tamaño y aislamiento de los parches tengan una influencia directa sobre el emparejamiento de los machos. Este reducido éxito de emparejamiento en los parches pequeños puede explicarse por el bajo número de territorios (i.e. coespecíficos) que presentan estos parches. Las hembras podrían evaluar la calidad de los parches en función del número de coespecíficos territoriales ("conspecific attraction hypothesis"; Smith \& Peacock 1990), de tal manera que los parches pequeños con pocos territorios serían evaluados como parches de baja calidad y las hembras preferirían no emparejarse en ellos (Robles et al. 2007b, 2008, Capítulo I). Apoyando esta hipótesis, las hembras dispersantes prefirieron asentarse en parches con mayores densidades de territorios (Capítulo II; Tabla 1). Otra hipótesis no excluyente con la atracción de coespecíficos es que las hembras prefieran no emparejarse en parches pequeños porque los machos en estos parches sean de baja calidad ("mate selection hypothesis"; Robles et al. 2008, Capítulo I).

En contra de nuestras expectativas, no encontramos un fuerte efecto del aislamiento de los parches en la mayor parte de los parámetros examinados (Tabla 1). Tan sólo el éxito de emparejamiento de los machos se vio negativamente afectado por el aislamiento derivado de la fragmentación del hábitat, pero como indicamos en el párrafo anterior, este efecto puede deberse a la correlación del aislamiento con otros factores tales como el tamaño de los parches y el número de territorios en los mismos más que al aislamiento per se. La baja influencia del aislamiento puede deberse a que los parches de hábitat en nuestra área de estudio están bien conectados, tal vez porque la matriz de robledal joven y bosque de ribera puede mitigar en parte los efectos del distanciamiento entre los parches proporcionando a los juveniles alimento y cobijo frente a los depredadores durante los movimientos dispersivos (Robles et al. 2007b, Ciudad et al. 2009, Capítulo II, Capítulo III). Incluso aunque los robledales jóvenes, los cuales cubren una parte substancial del área de estudio (ver Introducción 
General), sean evitados por los juveniles durante el periodo post-vuelo que abarca en parte la dispersión, son necesarios más análisis para examinar la influencia de estos bosques en los movimientos dispersivos de los picos. Alternativamente, el aislamiento entre parches puede no ser suficientemente importante como para provocar efectos negativos en la población de pico mediano (Capítulo II, Capítulo IV).

Nuestros resultados contrastan con aquéllos de estudios previos que muestran un efecto de la fragmentación sobre la supervivencia y la reproducción de algunas aves forestales, principalmente migrantes neotropicales que nidifican en Norte América (ej. Donovan et al. 1995, Robinson et al. 1995, Porneluzi \& Faaborg 1999, Bayne \& Hobson 2001, Doherty \& Grubb 2002). Esta discrepancia entre estudios podría explicarse por las diferencias históricas y actuales en los cambios del paisaje entre Europa y Norte América. En Europa, las duras condiciones experimentadas durante el Pleistoceno han llevado a la extinción de numerosos especialistas de hábitat, de tal manera que las especies que han sobrevivido son aquéllas que mejor han soportado las perturbaciones ambientales (ej. la fragmentación del hábitat). Por el contrario, las especies de Norte América no han estado sometidas a las severas condiciones del Pleistoceno en Europa, así que las especies más sensibles a los cambios ambientales aún sobreviven en la actualidad y se ven negativamente afectadas por las rápidas perturbaciones inducidas por el hombre en nuestros días (Mönkkönen \& Welsh 1994, Robles et al. 2007b).

Por otra parte, las diferencias en la ecología de las especies pueden influir en los resultados de los distintos estudios. El lugar de nidificación puede condicionar el efecto de la fragmentación sobre la supervivencia y el éxito reproductor. De esta forma, las especies que anidan en el interior de cavidades, como el pico mediano, pueden verse menos afectadas por la fragmentación del hábitat que las especies que anidan en el exterior, al estar las primeras menos expuestas a la depredación y al parasitismo de cría (Robles et al. 2007b, 2008, Capítulo I). El reparto de las labores de cría entre ambos padres y la aparente falta de una dispersión sesgada hacia uno de los sexos (Capítulo II), pueden contribuir a que no exista un mayor riesgo de mortalidad para uno de los sexos en el pico mediano (Robles et al. 2007b), como se ha sugerido en 
otras especies para explicar el bajo éxito de emparejamiento de los machos en paisajes fragmentados (ej. Gibbs \& Faaborg 1990).

Finalmente, las diferencias metodológicas también podrían explicar las diferencias entre estudios. Las estimaciones de supervivencia realizadas a partir de reobservaciones de aves anilladas pueden llevar a asumir erróneamente una falta de efecto o incluso efectos positivos de la fragmentación (Robles et al. 2007b). Esto se debe a que, con frecuencia, los estudios estiman la supervivencia en parcelas de estudio de pequeño tamaño que cubren todo el área de los parches pequeños pero sólo una parte de los parches grandes, lo que lleva a que los individuos en parches grandes tengan menores probabilidades de detección ya que pueden perderse fuera de las parcelas de estudio dentro de los parches (Robles et al. 2007b). Por su parte, en los estudios de dispersión, la comparación entre áreas de estudio continuas pequeñas y áreas fragmentadas grandes puede llevar a concluir que se da un incremento de la distancia de dispersión en zonas más fragmentadas, debido en realidad a la mayor probabilidad de que los movimientos más largos se pierdan fuera del área muestreada en las áreas continuas (Koenig et al. 1996, Capítulo II). Para paliar los efectos de estas diferencias metodológicas en estudios de supervivencia y dispersión en relación a la fragmentación, es recomendable la utilización de técnicas de radio-seguimiento, la ampliación del área de prospección de individuos anillados y la comparación de estos parámetros entre grandes áreas fragmentadas y continuas de tamaño similar (Robles et al. 2007b, Capítulo II).

\section{Efectos de la alteración del hábitat}

En nuestro sistema de estudio, el pico mediano habita en los robledales viejos (bosques maduros y dehesas) con una alta densidad de robles grandes importantes para su alimentación y como sitios de cría, mientras que los robledales jóvenes más degradados con un déficit de robles grandes son evitados tanto por los adultos durante el periodo reproductivo (Robles et al. 2007a) como por los juveniles en el periodo post-vuelo (Ciudad et al. 2009, Capítulo III; Tabla 1). Incluso considerando solamente los robledales viejos, aquéllos más degradados (i.e. con menores 
densidades de robles grandes importantes para la alimentación) tienen menos probabilidades de ser ocupados por picos medianos territoriales (Capítulo IV; Tabla 1).

Estos resultados muestran que la degradación del hábitat (i.e. robledales viejos) limita seriamente la distribución de los picos medianos en la Cordillera Cantábrica. Apoyando esta hipótesis, los juveniles nacidos en parches de hábitat de baja calidad (i.e. los parches más degradados) fueron más proclives a abandonar el parche natal, lo cual sugiere que la dispersión es un mecanismo comportamental que permite a las aves escapar de las condiciones adversas derivadas de la degradación del hábitat (Capítulo II; Tabla 1).

Tabla 1. Efectos de varios factores asociados con los procesos de fragmentación, pérdida y alteración del hábitat sobre los parámetros analizados en la población de pico mediano de la Cordillera Cantábrica. En números romanos se indica el capítulo en el que se analizó cada parámetro.

\begin{tabular}{|c|c|c|c|}
\hline & \multicolumn{2}{|c|}{ FRAGMENTACIÓN Y PÉRDIDA } & \multirow{2}{*}{$\begin{array}{c}\text { ALTERACIÓN } \\
\begin{array}{c}\text { Degradación del } \\
\text { hábitat }\end{array}\end{array}$} \\
\hline & $\begin{array}{c}\text { Reducción } \\
\text { tamaño parches }\end{array}$ & $\begin{array}{l}\text { Reducción } \\
\text { conectividad }\end{array}$ & \\
\hline Reproducción (I) & Baja influencia & Baja influencia & Baja influencia \\
\hline Emparejamiento (I) & Efecto negativo & Efecto negativo & Baja influencia \\
\hline \multicolumn{4}{|l|}{ Dispersión (II) } \\
\hline a) Emigración & Baja influencia & Baja influencia & Efecto positivo \\
\hline b) Inmigración & Baja influencia & Baja influencia & Efecto negativo \\
\hline Selección hábitat juveniles (III) & & & Efecto negativo \\
\hline \multicolumn{4}{|l|}{ Colonización/extinción (IV) } \\
\hline a) Colonización & Efecto negativo & Baja influencia & Baja influencia \\
\hline b) Extinción & Baja influencia & Baja influencia & Baja influencia \\
\hline Ocupación (IV) ${ }^{*}$ & Efecto negativo & Baja influencia & Efecto negativo \\
\hline Regularidad de ocupación (IV) & Baja influencia & Baja influencia & Baja influencia \\
\hline Supervivencia $^{* *}$ & Baja influencia & Baja influencia & \\
\hline
\end{tabular}

\footnotetext{
* Basado en los resultados del Capítulo IV y en Robles et al. 2007a

** Basado en Robles et al. 2007b.
} 


\section{Implicaciones en la conservación del pico mediano}

Como hemos visto en apartados anteriores, los factores que pueden amenazar de manera más importante la persistencia del pico mediano en la Cordillera Cantábrica son la degradación del hábitat y la reducción del tamaño de los parches asociada a los procesos de pérdida y fragmentación del hábitat. Por lo tanto, los planes de gestión para la conservación del pico mediano deberían ir encaminados a: (a) preservar los parches grandes, (b) incrementar el tamaño de los parches pequeños y (c) aumentar la calidad de los parches más degradados.

El primer paso sería proteger los parches de hábitat (i.e. robledales maduros y dehesas de roble) grandes de la pérdida y la degradación del hábitat por cambios en el uso del suelo tales como la sustitución del robledal por plantaciones de coníferas, la transformación en zonas agrícolas, las actividades extractivas de madera que comprometan una densidad suficiente de robles grandes o el desarrollo de proyectos urbanísticos y grandes infraestructuras. Los parches pequeños podrían agrandarse mediante cortas selectivas de robles de pequeño tamaño y limpieza de matorral en los robledales jóvenes adyacentes para permitir el crecimiento de árboles grandes (Ciudad et al. 2009, Capítulo III).

Las medidas para promover la calidad del hábitat deben estar dirigidas a mantener elevadas densidades de árboles importantes para la alimentación y la reproducción del pico mediano. Como valores de referencia, los territorios de los adultos tuvieron una densidad media de 66 robles grandes ( $\geq 37 \mathrm{~cm} \mathrm{DBH)} \mathrm{y} 30$ árboles potenciales de cría por hectárea (Robles et al. 2007a); mientras que las áreas de campeo de los juveniles tuvieron una densidad media de 141 árboles $>22 \mathrm{~cm} \mathrm{DBH}$ y 44 árboles $>33 \mathrm{~cm} \mathrm{DBH}$ por hectárea (Ciudad et al. 2009, Capítulo III). En este sentido, el mantenimiento de los usos tradicionales, especialmente de la ganadería extensiva que durante siglos ha modelado las características del paisaje de la Cordillera Cantábrica, podría ser un buen aliado para la persistencia del pico mediano. Aparte de evitar la transformación hacia otras actividades económicas menos compatibles con la conservación y de prevenir la homogeneización de los robledales jóvenes evitando el crecimiento de una elevada densidad de robles pequeños que compiten fuertemente entre sí (i.e. su crecimiento en grosor se ve limitado), permitiría preservar un patrimonio cultural exclusivo de la 
Península Ibérica como son las dehesas de roble melojo (Luis-Calabuig et al. 1993, Blanco et al. 1997, Camprodón 2001, De Groot \& Ramakrishnan 2005, Ciudad et al. 2009, Capítulo III).

El aislamiento entre los parches de hábitat del pico mediano ha tenido poca influencia en los procesos analizados, por lo que no parece necesario establecer medidas específicas para mejorar la conectividad del paisaje. Sin embargo, el mantenimiento de una matriz de hábitat compuesta por robledales jóvenes, bosques de ribera y linderos arbóreos de zonas agrícolas podría ser importante para la movilidad de los individuos entre parches (Robles 2004, Ciudad et al. 2009, Capítulo III). Además, los resultados de selección de hábitat de los juveniles (i.e. los principales dispersantes) indican que las plantaciones de coníferas fueron fuertemente evitadas (Ciudad et al. 2009, Capítulo III), sugiriendo que estas plantaciones podrían llegar a afectar a la conectividad del hábitat del pico mediano. No obstante, sería necesaria la realización de análisis de movimientos de individuos radio-marcados en nuestra área de estudio y la comparación con otras áreas con una matriz de diferentes características para poder confirmar estas hipótesis.

Al margen de las características del hábitat, hemos observado que la presencia de otros individuos de pico mediano puede favorecer el asentamiento de los juveniles en dispersión y el emparejamiento de los adultos territoriales (Capítulos I y II). Por tanto, la atracción de coespecíficos podría emplearse como una herramienta en los planes de conservación, reproduciendo vocalizaciones de la especie para atraer a las aves en dispersión hacia parches vacíos de alta calidad y favorecer el éxito de emparejamiento (Ward \& Schlossberg 2004, Capítulos I y II). En cualquier caso, este tipo de estímulos artificiales debe utilizarse con precaución para evitar atraer a las aves hacia trampas ecológicas, donde se ponga en peligro su eficacia biológica (Ahlering \& Faaborg 2006, Capítulo II). 


\section{Futuras líneas de investigación}

\section{1) Movilidad y flujo génico}

Con datos de seguimiento de juveniles radio-marcados de pico mediano obtenidos durante los últimos años en la población de la Cordillera Cantábrica, pretendemos evaluar cómo se mueven las aves forestales en paisajes heterogéneos. De esta forma, trataremos de identificar los componentes del paisaje que facilitan los movimientos entre los parches de hábitat durante la dispersión y que podrían ser importantes para mantener la conectividad de la población.

Por otra parte, a partir del genotipado de muestras de ADN y mediante el uso de 12 marcadores (microsatélites) altamente polimórficos desarrollados para esta especie (Vila et al. 2008), intentaremos determinar la posible influencia de la fragmentación del hábitat sobre la estructura genética de la población. Con esta información, junto con los datos de los movimientos de las aves obtenidos mediante radio-seguimiento y marcaje-reobservación de individuos anillados, pretendemos comprobar la existencia de componentes del paisaje que puedan estar reduciendo la movilidad, el flujo génico y la diversidad genética de la población.

\section{2) Efecto del cambio climático sobre la persistencia del pico mediano}

Nuestra población de estudio es una población periférica, al estar situada en el límite suroccidental de distribución mundial de la especie (Pasinelli 2003, Robles et al. 2007a) y ocupar un hábitat aparentemente subóptimo para el pico mediano (melojares sujetos a condiciones de sequía estival). Según algunos estudios, las poblaciones periféricas ocupan hábitats menos favorables, presentan densidades más bajas y tienen menor probabilidad de recibir inmigrantes que las poblaciones centrales, por lo que son más sensibles a los cambios ambientales y por tanto sufren un mayor riesgo de extinción (Brown 1984, Gaston 1990, Brown et al. 1995, Guo et al. 2005). Por el contrario, otras teorías defienden que la pérdida de las poblaciones periféricas puede mermar la habilidad de las especies para adaptarse a los futuros cambios ambientales globales y podría reducir su potencial de especiación (Channell \& Lomolino 2000). En ambos casos, la conservación de esta población podría tener una gran relevancia en el 
contexto del cambio climático, puesto que presentaría mayor riesgo de extinción que las poblaciones centrales (en caso de ser más sensible a los cambios ambientales) o podría contribuir a la persistencia de la especie (en caso de presentar una mayor capacidad de adaptación frente al calentamiento global).

Con el fin de evaluar la sensibilidad potencial de esta población meridional de pico mediano frente al calentamiento global derivado del cambio climático actual, en el futuro pretendemos examinar las relaciones entre el tiempo atmosférico y varios parámetros demográficos tales como la elección del momento de cría, el éxito reproductivo o la supervivencia de las aves. Además, pretendemos comparar la variabilidad genética de nuestra población con la de otras poblaciones del centro del rango de distribución de la especie. De existir una diferenciación genética entre poblaciones, tal vez podría deberse a que los picos medianos cantábricos hayan desarrollado adaptaciones locales a este ambiente meridional.

3) Utilización de las cavidades de cría del pico mediano por ocupantes secundarios

Aprovechando la información de cavidades de cría de pico mediano recogida durante estos años, se ha abierto una nueva línea de investigación para determinar el uso y la disponibilidad de sitios de cría para las aves nidificantes secundarias en cavidades en los bosques caducifolios. Pretendemos determinar si la disponibilidad de sitios de cría es un factor limitante en parcelas con distinto nivel de degradación y si el pico mediano, como creador de cavidades, es una especie clave (keystone species; Power et al. 1996) que influye fuertemente en la estructura de la comunidad de aves nidificantes secundarias.

\section{Referencias bibliográficas}

Ahlering, M. A. \& FAABORG, J. 2006. Avian habitat management meets conspecific attraction: if you build it, will they come? The Auk 123: 301-312.

BAYNE, E. M. \& HOBSON, K. A. 2001. Effects of habitat fragmentation on pairing success of ovenbirds: importance of male age and floater behavior. The Auk 118: 380-388. 
Blanco, E., Casado, M. A., Costa, M., Escribano, R., Génova, M., Gómez, A., Gómez, F., Moreno, J. C., Morla, C., Regato, P. \& Sáinz, H. 1997. Los Bosques Ibéricos. Una interpretación geobotánica. Planeta, Barcelona.

BROWN, J. H. 1984. On the relationship between abundance and distribution of species. American Naturalist 124: 255-279.

Brown, J. H., Mehlman, D. W. \& Stevens, G. C. 1995. Spatial variation in abundance. Ecology 76: 2028-2043.

BURKE, D. M. \& NOL, E. 1998. Influence of food abundance, nest-site habitat, and forest fragmentation on breeding ovenbirds. The Auk 115: 96-104.

CAMPRODÓN, J. 2001. Tratamientos forestales y conservación de la fauna vertebrada. En: Camprodón, J. \& Plana, E. (Eds.), Conservación de la biodiversidad y gestión forestal. Edicions Universitat de Barcelona, pp. 135-179.

Channell, R. \& Lomolino, M. V. 2000. Dynamic biogeography and conservation of endangered species. Nature 403: 84-86.

Ciudad, C., Robles, H. \& Matthysen, E. 2009. Postfledging habitat selection of juvenile middle spotted woodpeckers: a multi-scale approach. Ecography 32: 676-682.

COOPER, C. B. \& WALters, J. R. 2002. Experimental evidence of disrupted dispersal causing decline of an Australian passerine in fragmented habitat. Conservation Biology 16: 471-478.

DALE, S. 2001. Female-biased dispersal, low female recruitment, unpaired males, and the extinction of small and isolated bird populations. Oikos 92: 344-356.

De Groot, R. \& Ramakrishnan, P. S. 2005. Cultural and amenity services. En: Hassan, R., Scholes, R. \& Ash, N. (Eds.), Ecosystems and human well-being: current state and trends, Vol. 1. Washington, D. C., Island Press, pp. 455-476.

DOHERTY, P. F. \& GRUBB, T. C. 2002. Survivorship of permanent-resident birds in a fragmented forested landscape. Ecology 83: 844-857.

Donovan, T. M., Lamberson, R. H., Kimber, A., Thompson III, F. R. \& FaAborg J. 1995. Modelling the effects of habitat fragmentation on source and sink demography of neotropical migrant birds. Conservation Biology 9: 1396-1407. 
FAHRIG, L. 2003. Effects of habitat fragmentation on biodiversity. Annual Review of Ecology, Evolution and Systematics 34: 487-515.

GASTON, K. J. 1990. Patterns in the geographical ranges of species. Biological Review 65: 105-129.

GIBBS, J. P. \& FAABORG J. 1990. Estimating the viability of ovenbird and Kentucky warbler populations in forest fragments. Conservation Biology 4: 193-196.

Guo Q., Taper M., Schoenberger M. \& Brandle J. 2005. Spatial-temporal population dynamics across species range: From centre to margin. Oikos 108: 47-57.

Koenig, W. D., Van Vuren, D. \& Hooge, P. N. 1996. Detectability, philopatry, and the distribution of dispersal distances in vertebrates. Trends in Ecology and Evolution 11: $514-517$.

Lens, L., Van Dongen, S., Norris, K., Guitiru, M. \& Matthysen E. 2002. Avian persistence in fragmented rainforest. Science 298: 1236-1238.

LUCK, G. W. 2003. Differences in the reproductive success and survival of the rufous treecreeper (Climacteris rufa) between a fragmented and unfragmented landscape. Biological Conservation 109: 1-14.

luis-Calabuig, E., Tárrega, R., Calvo, L., Marcos, E., Valbuena, L. \& Alonso, I. 1993. Análisis fisionómico de los ecosistemas de Quercus pirenaica Willd. en la Cuenca del Duero. Congreso Forestal Español, Lourizán, Pontevedra.

MÖNKKÖNEN, M. \& WELSH, D. A. 1994. A biogeographical hypothesis on the effect of human caused landscape changes on the forest bird communities of Europe and North America. Annales Zoologici Fennici 31: 61-70.

MURCIA, C. 1995. Edge effects in fragmented forests: implications for conservation. Trends in Ecology and Evolution 10: 58-62.

PasinelLI, G. 2003. Dendrocopos medius Middle Spotted Woodpecker. BWP Update 5: 49-99.

Porneluzi, P. A. \& FAABORG, J. 1999. Season-long fecundity, survival, and viability of ovenbirds in fragmented and unfragmented landscapes. Conservation Biology 13: 1151-1161. 
Power, M. E., Tilman, D., Estes, J. A., Menge, B. A., Bond, W. J., Mills, L. S., Daily, G., CAstilla, J. C., Lubchenco, J. \& PAine, R. T. 1996. Challenges in the quest of keystones. Bioscience 46: 609-620.

Robinson, S. K., Thompson III, F. R., Donovan, T. M., Whitehead, D. R. \& FaAborg J. 1995. Regional forest fragmentation and the nesting success of migratory birds. Science 267: 1987-1990.

RoBles, H. 2004. Distribución y estrategias de la vida del pico mediano Dendrocopos medius en una población fragmentada. El papel de la estructura del hábitat. Tesis doctoral, Universidad de León, León.

Robles, H., Ciudad, C., Vera, R., Olea, P. P., Purroy, F. J. \& Matthysen, E. 2007a. Sylvopastoral management and conservation of the middle spotted woodpecker at the south-western edge of its distribution range. Forest Ecology and Management 242: $343-352$.

Robles, H., Ciudad, C., Vera, R. \& Baglione, V. 2007b. No effect of habitat fragmentation on post-fledging, first-year and adult survival in the middle spotted woodpecker. Ecography 30: 685-694.

Robles, H., Ciudad, C., Vera, R., Olea, P. P. \& Matthysen, E. 2008. Demographic responses of middle spotted woodpeckers (Dendrocopos medius) to habitat fragmentation. The Auk 125: 131-139.

RooT, R. B. 1973. Organization of a plant-arthropod association in simple and diverse habitats: the fauna of collards (Brassica oleraceae). Ecological Monographs 45: 95120.

SMith, A. T. \& PeAcock, M. M. 1990. Conspecific attraction and the determination of metapopulation colonization rates. Conservation Biology 4: 320-323.

Vila, M., Robles, H., Ciudad, C., Olea, P. P. \& Baglione, V. 2008. Isolation and characterization of 12 microsatellites markers in the middle-spotted woodpecker (Dendrocopos medius). Molecular Ecology Resources 8: 415-417.

WARD, M. P. \& SChlossberG, S. 2004. Conspecific attraction and the conservation of territorial songbirds. Conservation Biology 18: 519-525. 
WilcoX, B. A. \& MURPHY, D. D. 1985. Conservation strategy: the effects of fragmentation on extinction. American Naturalist 125: 879-887.

ZANetTe, L., Doyle, P. \& TRÉmont, S. M. 2000. Food shortage in small fragments: evidence from an area-sensitive passerine. Ecology 81: 1654-1666. 


\section{CONCLUSIONES}

1. La reducción del tamaño de los parches de robledal viejo (robledal maduro y dehesas de roble), asociada a procesos de fragmentación y pérdida de hábitat, tiene un efecto negativo sobre la probabilidad de ocupación, el tamaño poblacional y la colonización de los parches por el pico mediano. Como resultado, la pérdida y fragmentación del hábitat pueden tener graves consecuencias para la persistencia del pico mediano en la Cordillera Cantábrica, donde una proporción muy baja de la superficie ( $\sim \%$ en el área de estudio) está ocupada por robledales viejos adecuados para la especie.

2. La degradación de los robledales viejos reduce la ocupación territorial del pico mediano. Además, los juveniles también prefieren los robledales viejos con altas densidades de robles de gran diámetro frente a los robledales más degradados durante el periodo post-vuelo. Por tanto, la degradación del hábitat puede tener serias consecuencias sobre la distribución del pico mediano.

3. La degradación del hábitat parece estimular la dispersión, puesto que los juveniles originarios de parches de baja calidad (i.e. los parches más degradados) son más proclives a abandonar el parche natal. Esto sugiere que la dispersión es un mecanismo comportamental que permite a las aves escapar de condiciones adversas.

4. La fragmentación, pérdida y alteración del hábitat no tiene una fuerte influencia sobre la reproducción del pico mediano.

5. La atracción de coespecíficos puede ser un mecanismo comportamental que favorece el asentamiento de los juveniles en parches adecuados para la cría, así como el éxito de emparejamiento de los machos territoriales. 
6. La reducción de la conectividad (i.e. el aumento del aislamiento), derivada de la fragmentación del hábitat, no tiene una fuerte influencia sobre la distribución, la abundancia, las tasas de colonización-extinción, la reproducción o la dispersión natal y de cría del pico mediano en nuestra área de estudio.

7. Las condiciones de forrajeo parecen dirigir, al menos parcialmente, las decisiones de uso del hábitat de los juveniles durante el periodo post-vuelo. Además, otros factores tales como la competencia intraespecífica o la búsqueda de futuros territorios de cría también pueden influir en estas decisiones.

8. Nuestros resultados contradicen las asunciones teóricas usadas con frecuencia en los modelos metapoblacionales que indican que la probabilidad de colonización de los parches aumenta con la conectividad y la probabilidad de extinción se incrementa al reducirse el tamaño de los parches. Por el contrario, en nuestro sistema de estudio la probabilidad de colonización se incrementa con el tamaño de los parches pero no con la conectividad, mientras que la probabilidad de extinción aumenta al reducirse los tamaños poblacionales pero no el tamaño de los parches. Por tanto, las asunciones de los modelos metapoblacionales deberían ser probadas para cada sistema de estudio.

9. Las medidas de gestión para la conservación de las poblaciones de pico mediano en la Cordillera Cantábrica deberían estar dirigidas principalmente hacia tres tipos de actuaciones: i) proteger los parches de hábitat (i.e. robledales viejos) grandes, ii) incrementar el tamaño de los parches pequeños de robledal viejo mediante cortas selectivas en los robledales jóvenes adyacentes, y iii) aumentar la calidad de los parches de hábitat más degradados incrementando la densidad de árboles de gran diámetro.

10. Como complemento a las medidas de gestión propuestas en el punto 9, el uso de la reproducción de vocalizaciones de la especie puede favorecer, mediante el mecanismo de atracción de coespecíficos, el asentamiento de los picos medianos en parches de hábitat grandes y de alta calidad. 


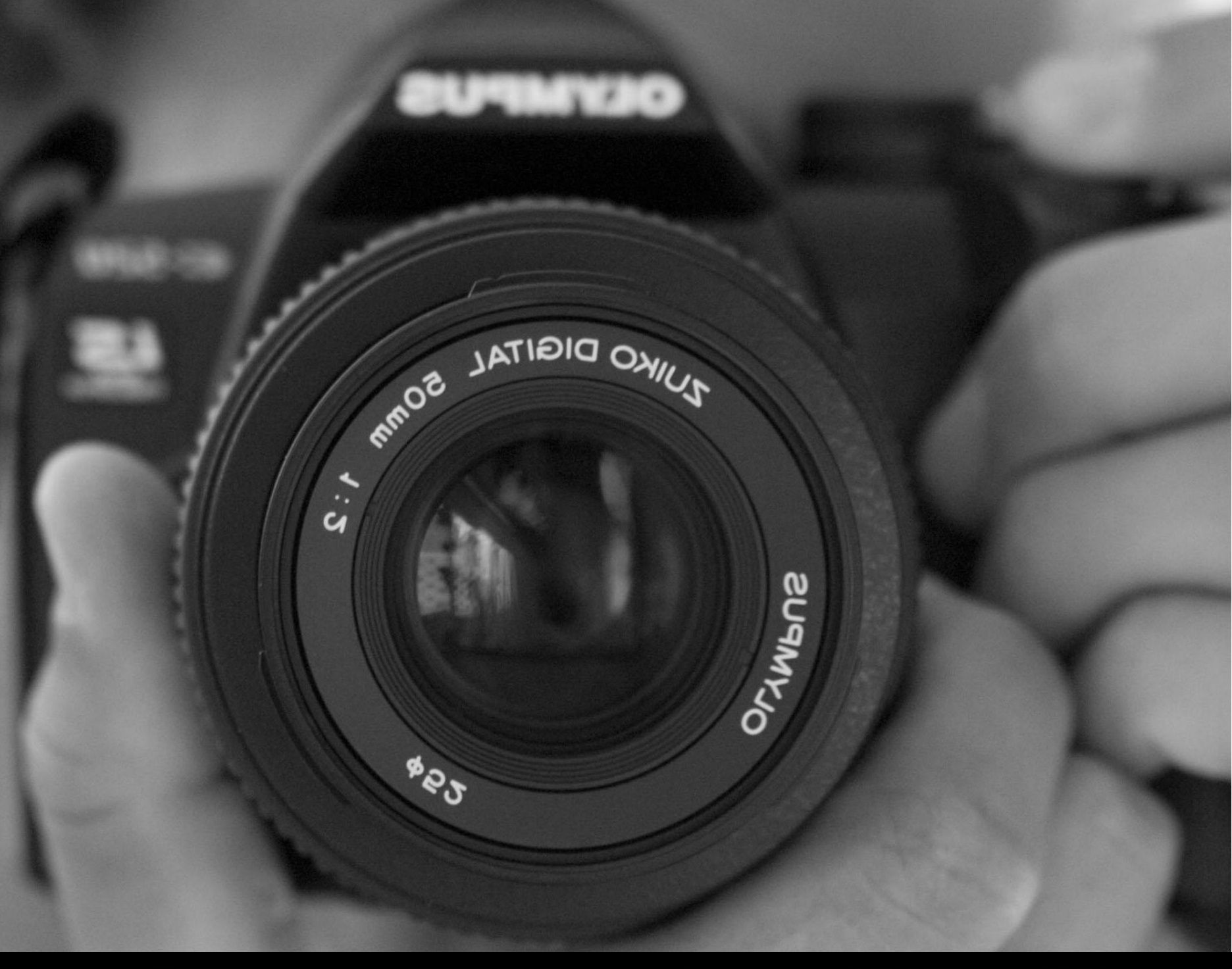

ANEXO FOTOGRÁFICO 


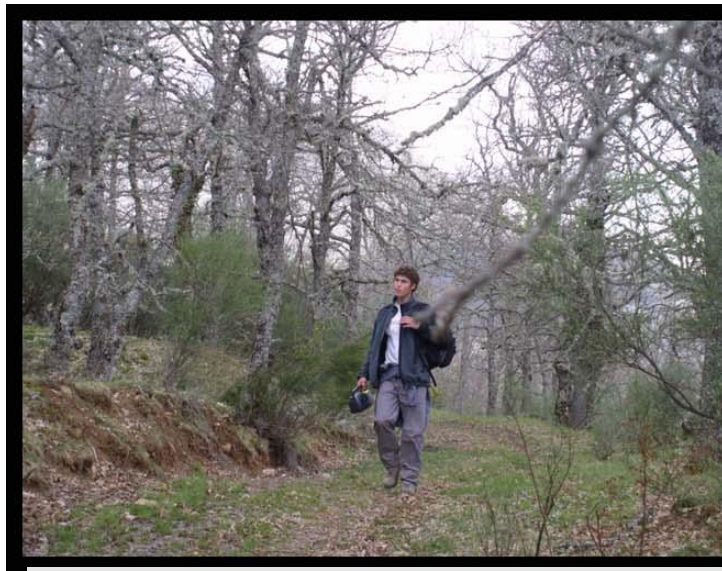

Foto 1. Reproducción de vocalizaciones de pico mediano en el interior de robledal maduro (Aída Olmo).

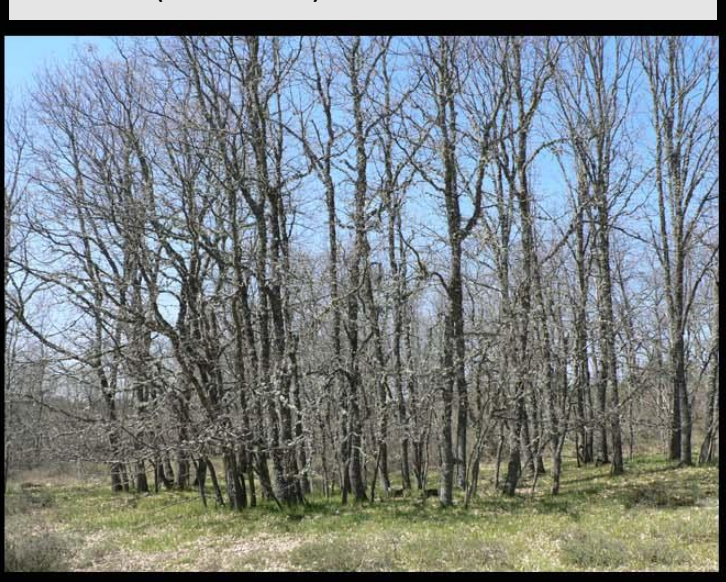

Foto 3. Robledal joven originado por rebrote, con muy baja densidad de robles de gran diámetro.

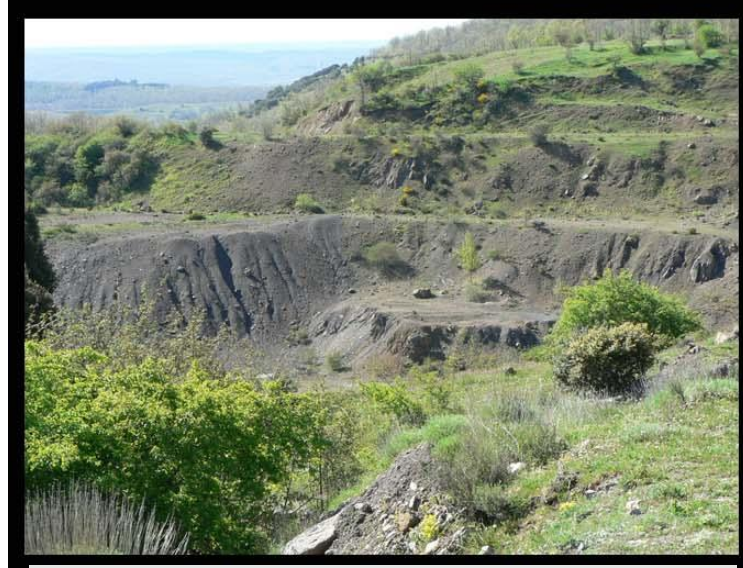

Foto 5. Antigua mina a cielo abierto para la extracción de carbón en Prado de la Guzpeña.

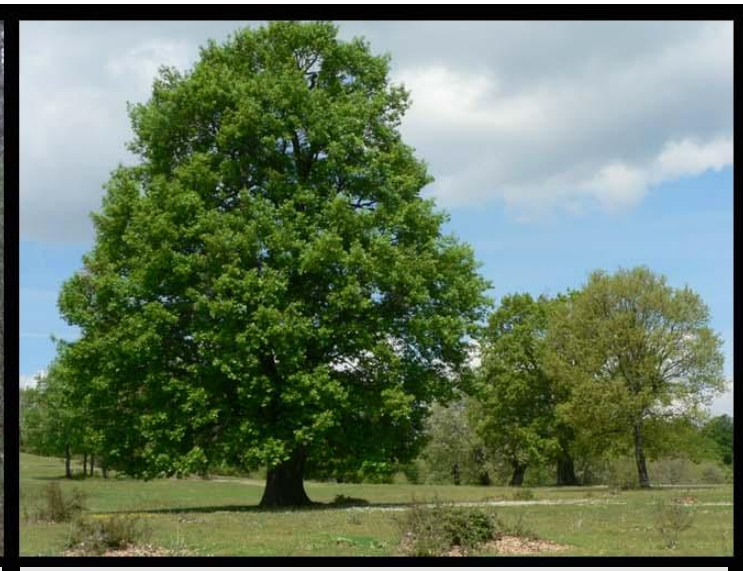

Foto 2. Dehesa de roble melojo.

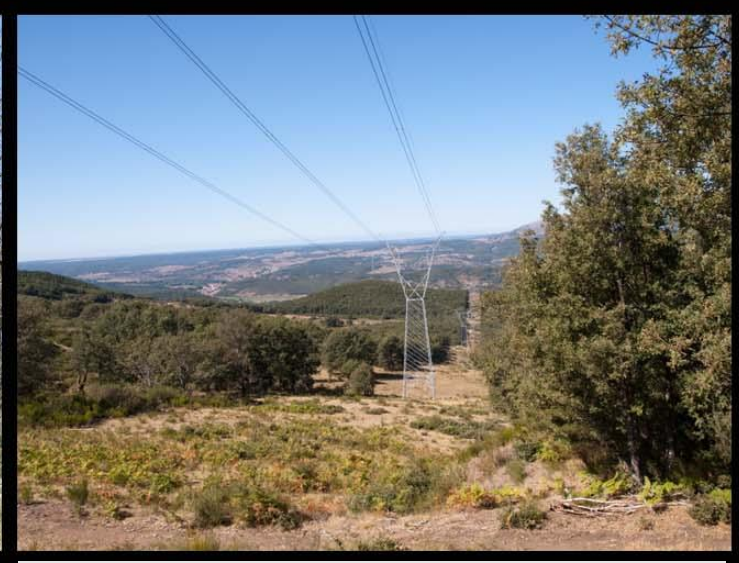

Foto 4. Pérdida y fragmentación de robledal maduro en Valderrueda debido a la construcción de la línea de alta tensión.

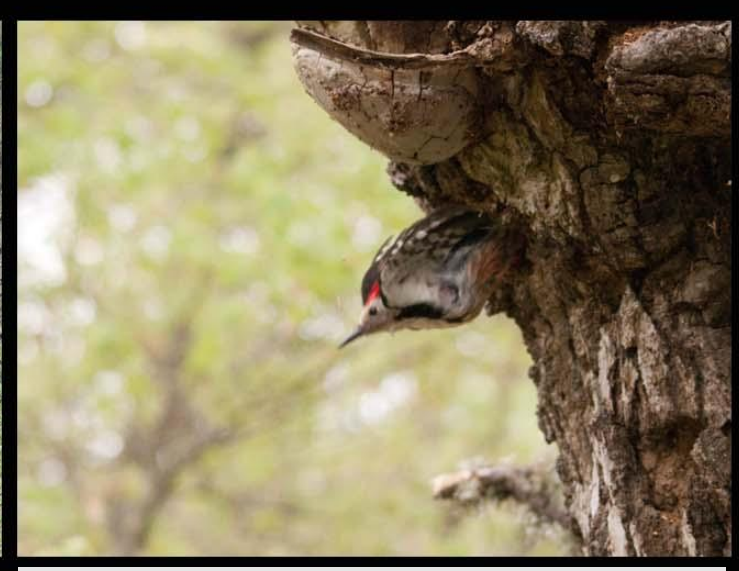

Foto 6. Macho de pico mediano saliendo de la cavidad de cría, construida bajo un hongo afiloforal y al lado de otros huecos antiguos. 


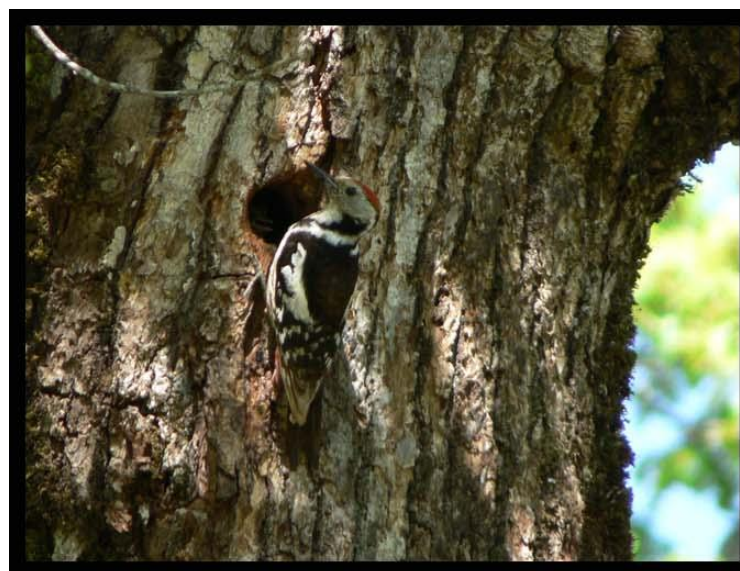

Foto 7. Hembra de pico mediano cebando a un pollo asomado a la entrada del nido.

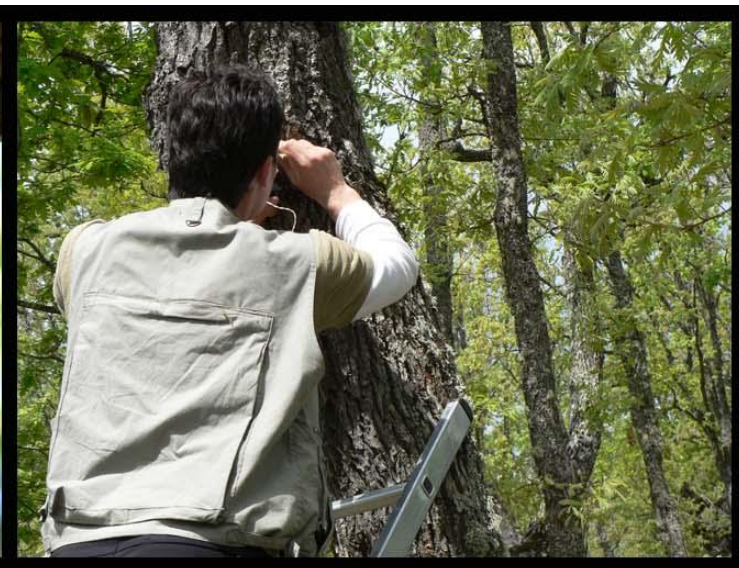

Foto 8. Revisión del interior de una cavidad de cría con ayuda de una lámpara y un espejo de dentista.

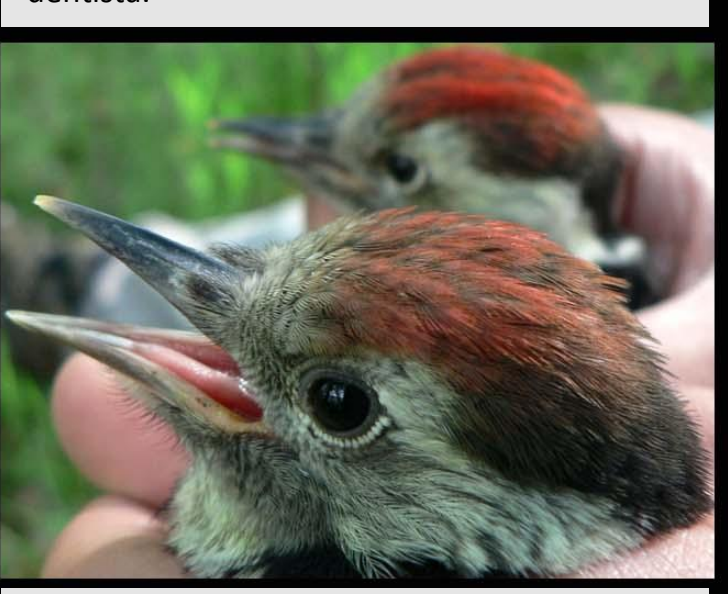

Foto 10. Pollos de pico mediano, hembra en primer término y macho al fondo

(distinguibles por la coloración de la corona).

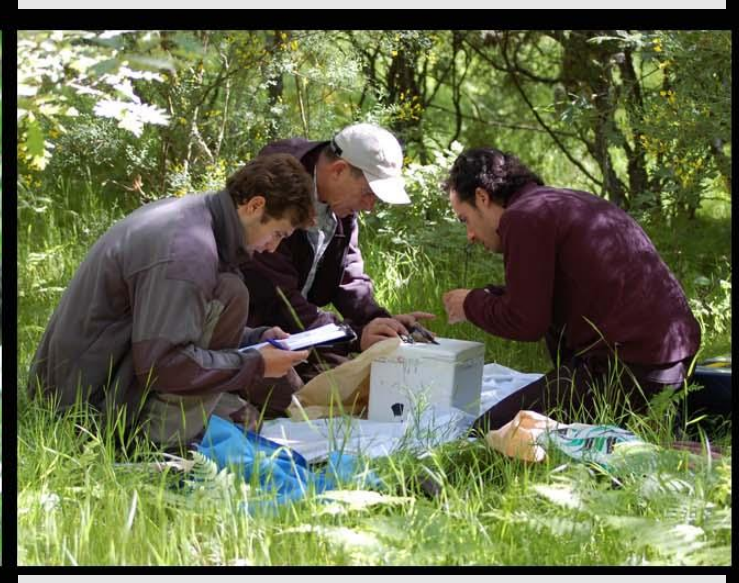

Foto 12. "Equipo mediano" colocando un radio-emisor a un juvenil (Gianluca Roncalli).

Foto 11. Pollo volande
abandonar el nido. 


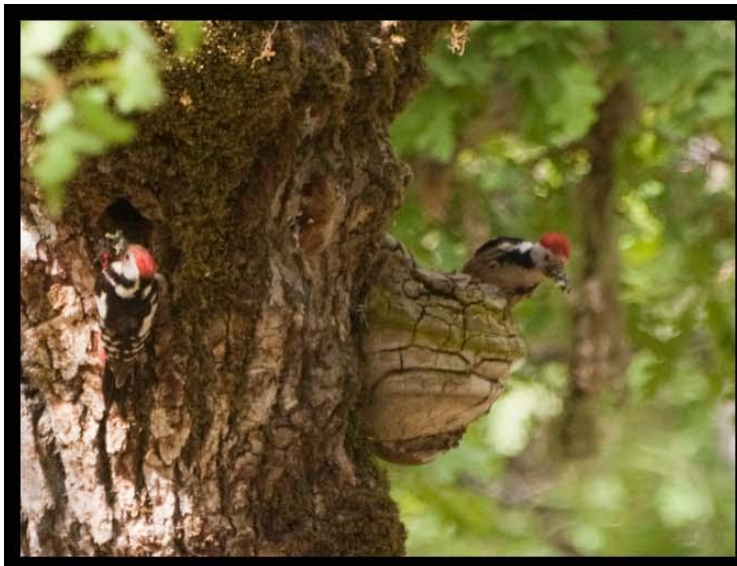

Foto 13. Pareja de picos medianos en las inmediaciones del nido, ambos marcados en años anteriores con anillas de colores.

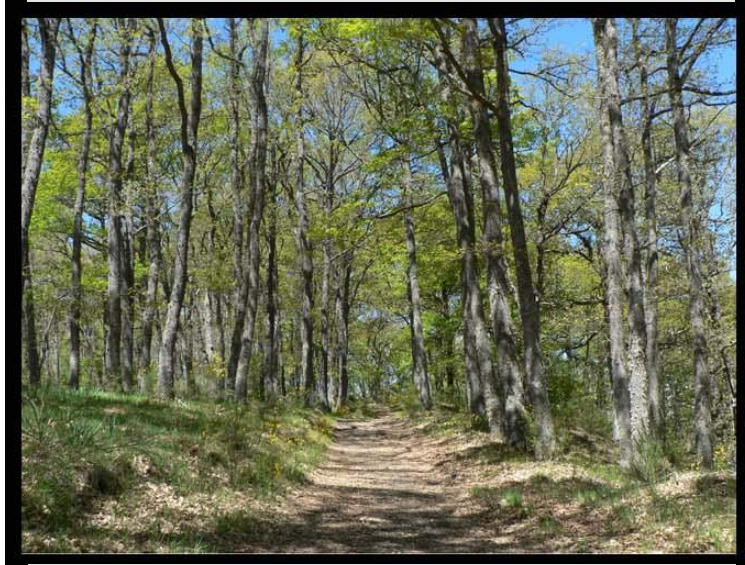

Foto 15. Parche de robledal maduro ocupado por picos territoriales todos los años de estudio.

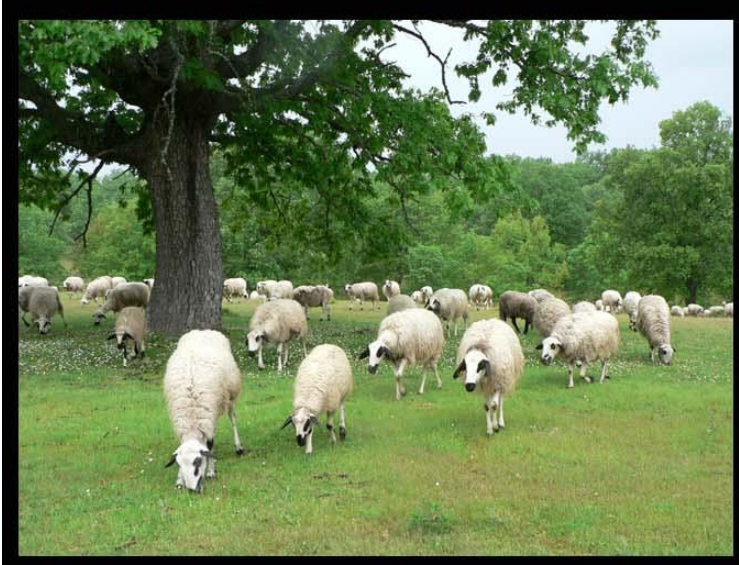

Foto 17. Rebaño de ovejas pastando en la dehesa de roble melojo de la Cota de Almanza.

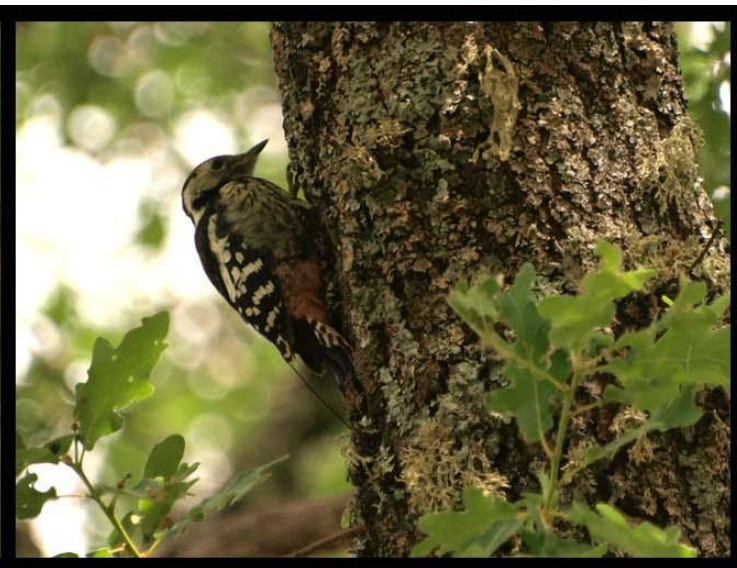

Foto 14. Juvenil radio-marcado alimentándose durante la dispersión en el tronco de un roble.

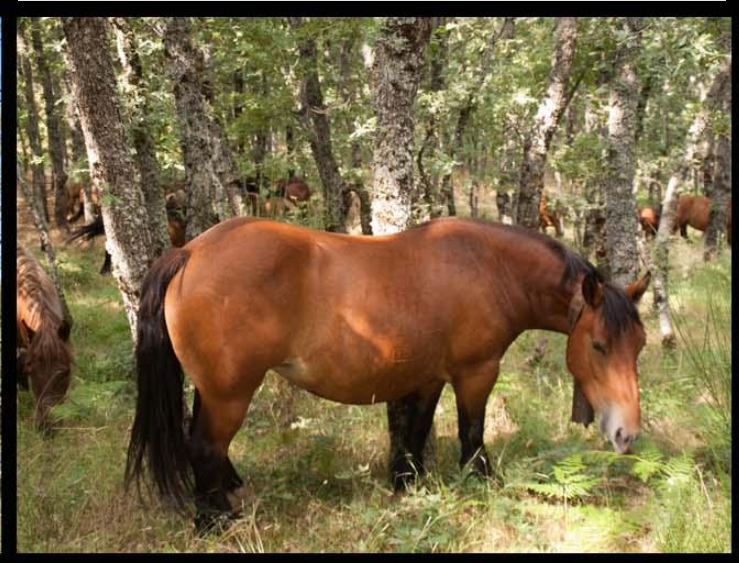

Foto 16. Caballos pastando en el interior de un robledal en los alrededores de Peñacorada.

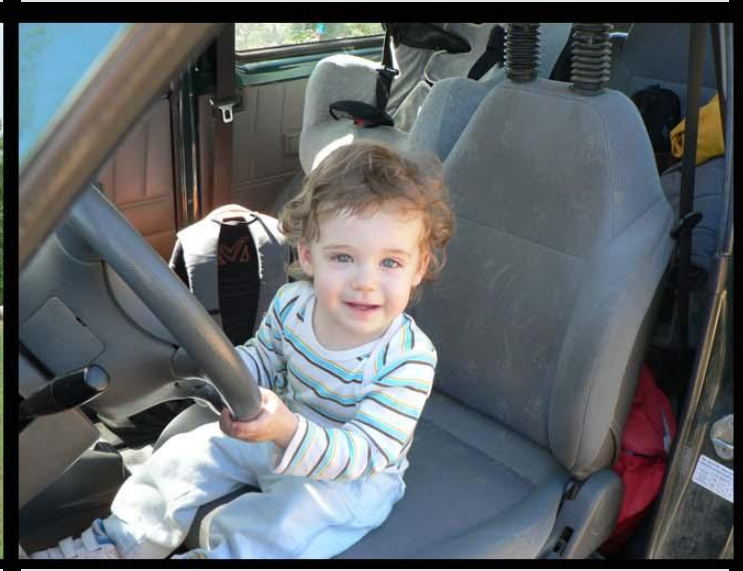

Foto 18. Pequeño ayudante de campo. 


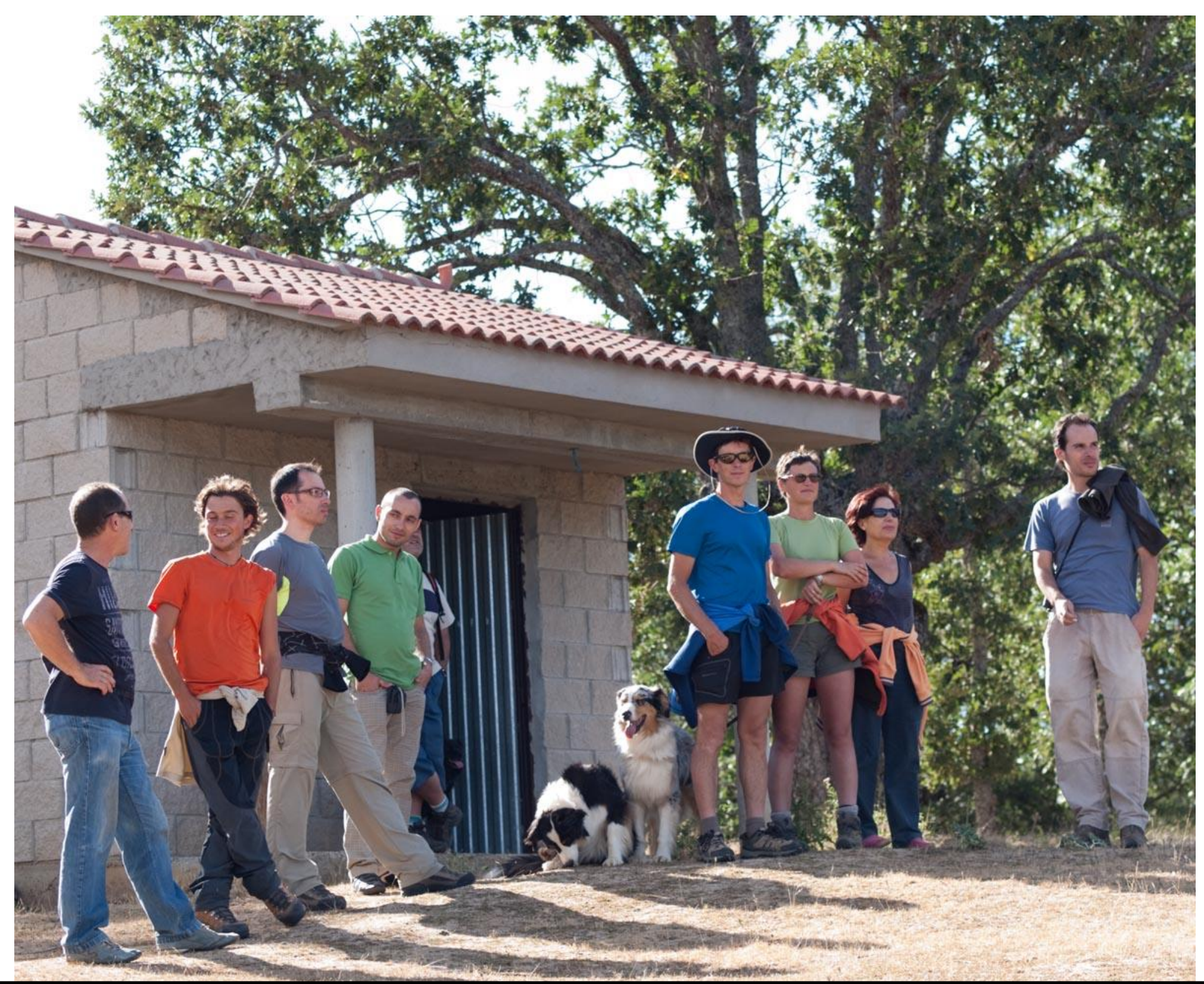

\section{AGRADECIMIENTOS}


Justo ahora va a hacer 8 años desde que vine a León y el principal culpable de ello y de que siga por aquí es Hugo Robles. A lo largo de todo este tiempo me ha enseñado muchas cosas, pero no sólo ha sido un gran director de tesis, también ha sido un buen amigo, me ha echado una mano cuando lo he necesitado, me ha prestado su casa, incluso a su familia y amigos. Gracias a su tenacidad y a su buen hacer hemos conseguido financiación, hemos sacado adelante un ambicioso proyecto y hasta parece que voy a lograr terminar la dichosa tesis. Mucha suerte allá donde vayas, seguro que te va a ir muy bien, porque te lo mereces.

Francisco José Purroy ha estado siempre ahí, dándome su apoyo como director y mostrando plena confianza en mi trabajo. Ha sido un auténtico placer acompañarle en los censos de avutardas, en los cursos, en los congresos, en las cenas... Un abrazo Pancho.

En el trabajo de campo ha colaborado mucha gente a lo largo de estos años, entre los que cabe destacar a: Marceliano Robles (Chano), Rubén Vera, Gianluca Roncalli, Gema Solano, Irene Marcos, Pedro Olea, Ángel de Frutos, Lieven Devreese, Andreia Penado, Aurora Santos, Marta Sampaio, Elfi Verschooren, Tamara Landzaat, Aída Olmo y Lorena Rodríguez.

Mención muy especial para Chano, que ha sido el mejor colaborador que se puede tener como técnico de campo, pasador de datos, administrador de material, gestor, amenizador de viajes... y en lo personal casi como un padre para mí.

Serguei Kossenko y Evgeniya Kaygorodova nos proporcionaron amablemente los datos de la población de medianos de Nerussa-Desna en Rusia para el capítulo de dispersión.

Pedro Olea, Erik Matthysen, Vittorio Baglione, Serguei Kossenko, Rubén Vera, Daniela Canestrari, Luc Lens, Diederik Strubbe, Mwangi Githiru y Stefan Van Dongen han aportado valiosas sugerencias en la redacción y en el análisis de algunos de los capítulos de la tesis.

La realización de análisis genéticos y el sexado molecular de los medianos ha sido posible gracias a la colaboración de Marta Vila y Nuria Remón (Universidad de A Coruña), y de José Antonio Dávila y su equipo (IREC).

Agradecer a Erik Matthysen y a toda la gente del Laboratorio de Ecología Animal de la Universidad de Amberes (Ximena, Diederik, Kassandra, Thijs, Frank, etc.) su cooperación durante mi estancia en Flandes. También a los habitantes de Hertog Jan, especialmente a mi buena amiga Adéla, y a Tamara por su hospitalidad. Dank je, děkuji, thank you... 
Mi estancia en el IREC, entre pipetas y PCRs, se hizo de lo más amena gracias a toda la maravillosa gente de ese centro: Dávila, Viñuela, David Canal, Fabián Casas, Araceli Barrajón, Inés Sanchez, Enric Ortega, Miguel Delibes, Lorenzo, Jorge y un muy largo etc.

Reconocer a Vittorio y a Daniela todo su apoyo, sus consejos, su disponibilidad para cualquier cosa en cualquier momento. Molte grazie per tutto. Vais a ser unos papis estupendos.

Ha sido un placer compartir vivencias con mis compañeros de Departamento: Patricia, Pedro, Ángel, Nico, Esther, David, Ángela, Laura, Manu, Sergio, Victor, Jose, Alejandra, Susana, Paula, Benito... Mención especial para Jose, que me ha salvado la vida en innumerables ocasiones con el ArcGIS, y para Nico, siempre dispuesto a echar una mano ante cualquier problema.

Rubén, Elisa y Tania además de grandes amigos fueron unos fantásticos compañeros de piso.

A mis amigos del Piru, a los que tengo tan abandonados, pero nunca me olvido de ellos. David (Puñalote) además de escaparse de vez cuando para venir al monte, ha sido una gran ayuda en el fascinante mundo de la fotografía y en el desquiciante mundo del Photoshop.

A mi familia, por sus ánimos y su comprensión. Especialmente a mis padres y a mi hermano, que me han ayudado económicamente, nutricionalmente y anímicamente en muchas ocasiones. A Tusa, a la que se echa tanto de menos. Gracias también por todo a mi familia satélite. A Aída y Leo tengo tanto que agradecerles que no hay suficiente espacio en el mundo.

Gracias a Antonio Álvarez, encargado de la Dehesa del Plumar, por todas las facilidades que siempre nos ha dado para poder trabajar en ese fabuloso lugar. También a los pastores y las gentes de Almanza, Llamas de Rueda, Mondreganes, Renedo, Espinosa, Robledo, Valle de las Casas, La Espina y demás pueblos por su comprensión, sus charlas, su ayuda en casos de emergencia y por seguir luchando por mantener vivos los usos tradicionales del campo.

Esta tesis doctoral ha sido posible gracias a una beca del programa de Formación del Profesorado Universitario del Ministerio de Educación y Ciencia. Los distintos estudios han sido financiados por el Ministerio de Educación y Ciencia (proyecto REN 2002-03587), la Xunta de Galicia (proyecto INCITE08PXIB103259PR) y la Junta de Castilla y León (proyecto LE017A05). Todos los estudios se han realizado bajo la autorización del Ministerio de Medio Ambiente y la Junta de Castilla y León. 


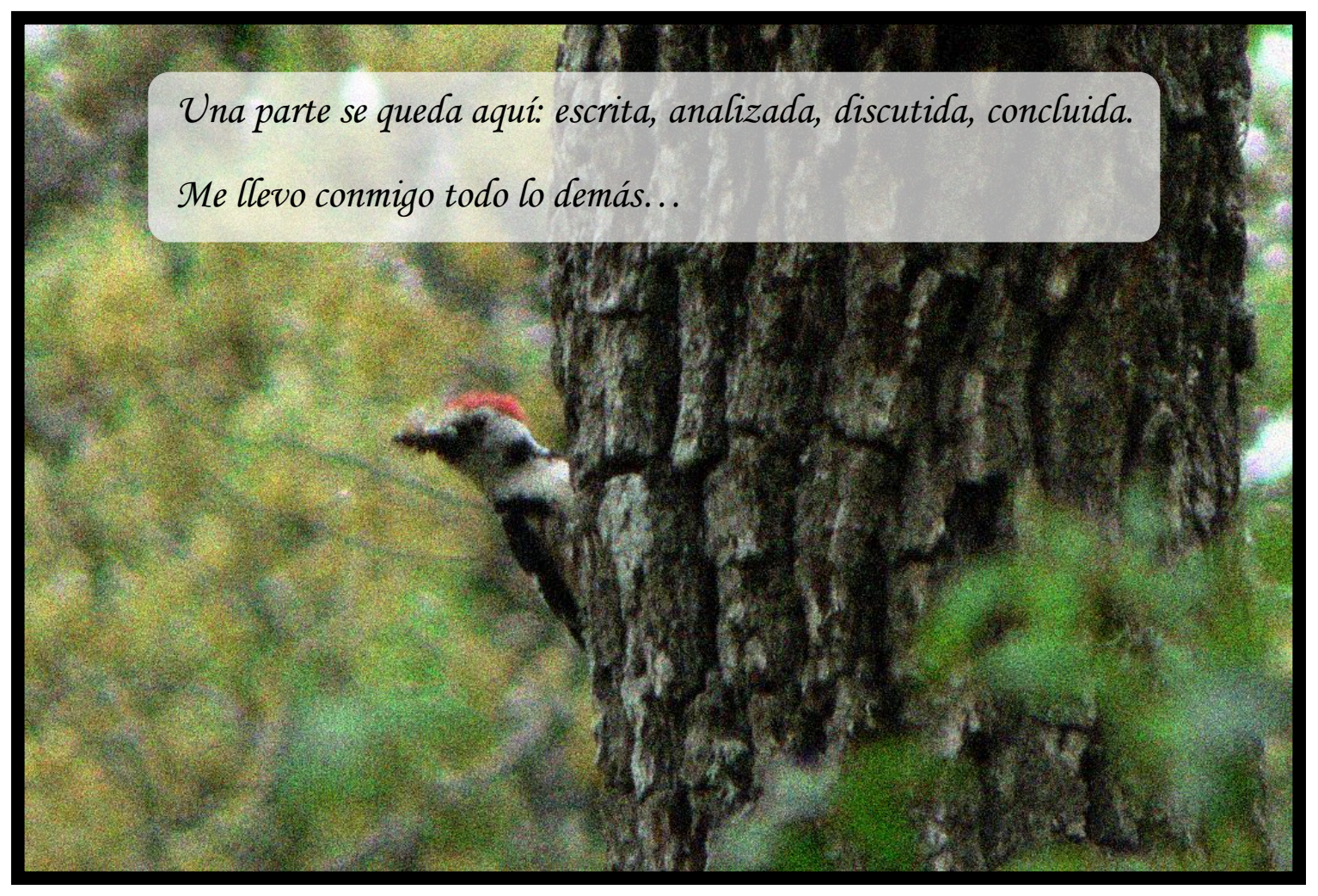

